\title{
1985 Annual Report on
}

\section{Alaska's Mineral Resources}

U.S. GEOLOGICAL SURVEY CIRCULAR 970

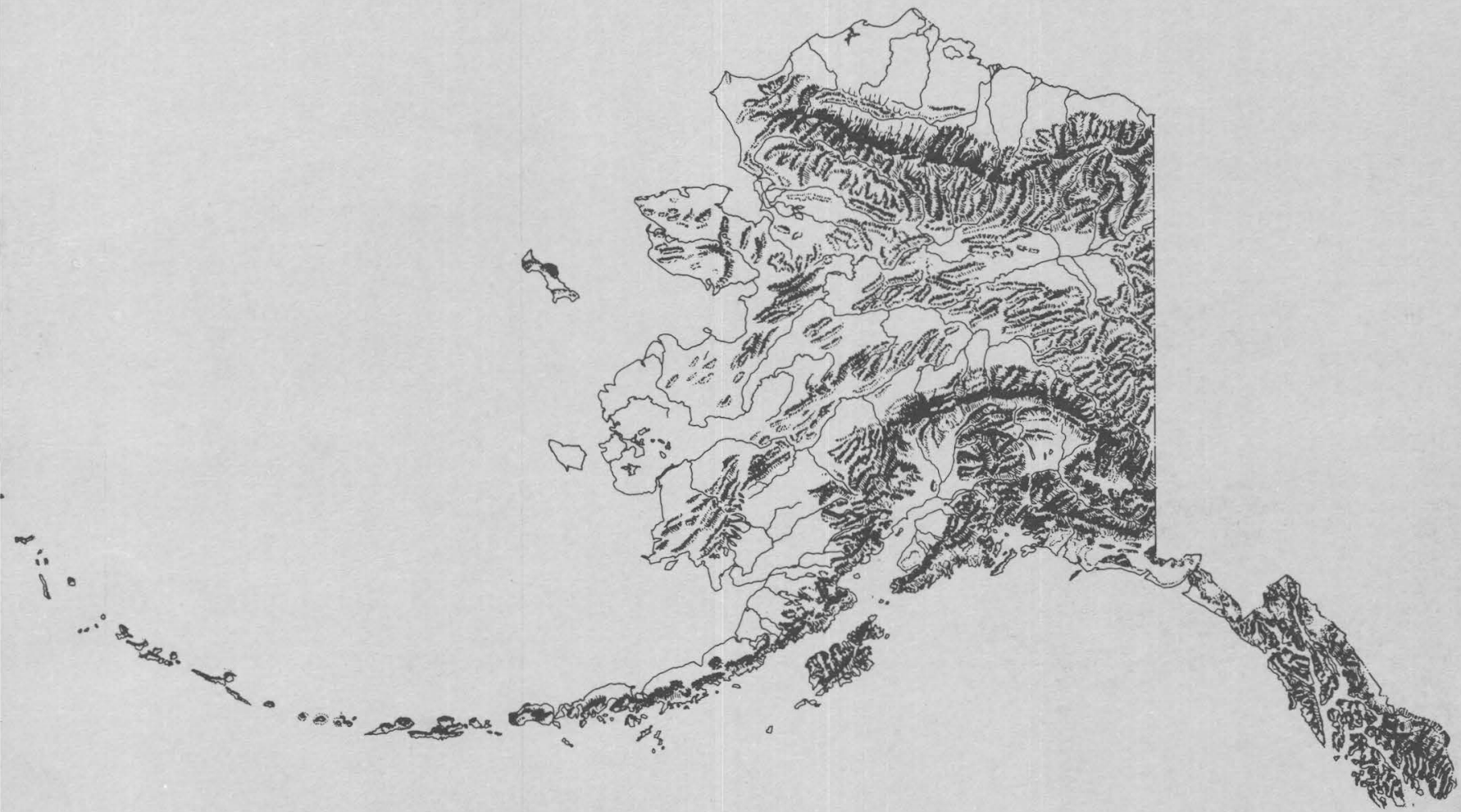

Prepared in cooperation with the

Bureau of Mines, the Bureau of Land

Management, the National Park Service,

the U.S. Fish and Wildlife Service, the

Department of Agriculture-Forest

Service, and the Department of Energy

As mandated by Section 1011 of the

Alaska National Interest Lands

Conservation Act, Public Law 96-487, of December 2, 1980

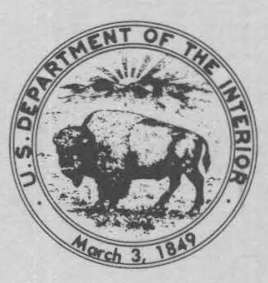




\section{Contributors to this report:}

Donald Baggs, Bureau of Mines James Barker, Bureau of Mines John Benson, Bureau of Land Management Philip Bigsby, U.S. Fish and Wildl ife Service Kenneth Bird, U.S. Geological Survey Robert Bottge, Bureau of Mines Fred Chiei, Department of Energy Roger Contor, National Park Service Norman Day, Forest Service Kendell Dickinson, U.S. Geological Survey Lynn Gr if $\mathrm{f}$ ths, National Park Service Donald Grybeck, U.S. Geological Survey Ted Heuer, U.S. Fish and Wildl ife Service Robert Hoekzema, Bureau of Mines Howard Metsker, U.S. Fish and Wildlife Service Richard Nadeau, U.S. Fish and Wildl ife Service Tom Pittman, Bureau of Mines

Robert Putz, U.S. Fish and Wildlife Service Gerald Reid, U.S. Fish and Wildlife Service James Richardson, Bureau of Land Management James Riehle, U.S. Geological Survey Gary Stackhouse, U.S. Fish and Wildlife Service Gary Stricker, U.S. Geological Survey 


\section{Annual Report on Alaska's Mineral Resources}

U.S. GEOLOGICAL SURVEY CIRCULAR 970

Prepared in cooperation with the Bureau of Mines, the Bureau of Land Management, the National Park Service, the U.S. Fish and Wildlife Service, the Department of Agriculture--Forest

Service, and the Department of Energy

As mandated by Section 1011 of the Alaska National Interest Lands Conservation Act, Public Law 96-487, of December 2, 1980 


\section{DEPARTMENT OF THE INTERIOR DONALD PAUL HODEL, Secretary}

\section{U.S. GEOLOGICAL SURVEY}

Dallas L. Peck, Director

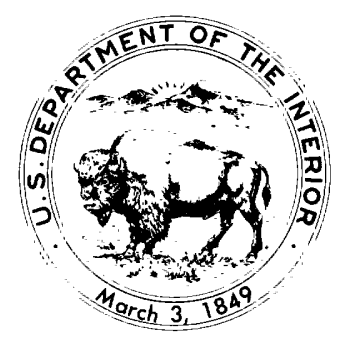

Free on application to Distribution Branch, Text Products Section,

U.S. Geological Survey, 604 South Pickett Street, Alexandria, VA 22304 
Summary ....................... 1

Oi 1 and gas................. 1

Ur anium resources.............. 2

Geothermal resources............ 2

Coal and peat................. 2

Nonfuel minerals............... 2

Introduct ion. .................. 3

Department of the Interior......... 3

U.S. Geological Survey........ 3

Bureau of Mines............ 5

Bureau of Land Management..... 6

National Park Service......... 7

U.S. Fish and Wildlife Service. 7

Department of Agriculture--

Forest Service............ 8

Department of Energy ............ 8

Contacts for further information.... 8

Oil and gas.................... 9

Activity by Federal agencies...... 9

Industry activity.............. 15

References cited............... 17

Uranium resources ................... 18

Activity by Federal agencies....... 18

References cited............... 20

Geothermal resources............... 20

Activity by Federal agencies...... 20

State studies................. 20

References cited............... 20
Page

Coal and peat................... 21

Activity by Federal agencies....... 21

State activity................ 21

Industry activity.............. 21

Activity in peat .............. 23

References cited.............. 23

Nonf uel minerals ................... 23

Activity by Federal agencies....... 25

State activities................ 34

Industry hardrock activity

in base metals............... 35

Industry hardrock activity

in precious metals............ 39

Placer mining for precious

metals.................... 41

Industrial minerals ............. 43

References cited............... 44

Selected references................ 45

U.S. Geological Survey............ 45

Bureau of Mines................ 52

Bureau of Land Management......... 53

Nat i ona 1 Park Service............. 54

U.S. Fish and Wildlife Service..... 54

Department of Agriculture--

Forest Service............... 54

Department of Energy............... 54

Other Federal agencies............ 54

Non-Federal publications......... 55

\section{ILUSTRATIONS}

Figures 1-9. Maps showing:

Page

1. Distribution of National Interest Lands and conservation units established by the National Interest Lands Conservation Act of 1980. .

2. Favorable Petroleum Geologic Provinces, areas of fered for lease, Arctic National Wildlife Refuge study area, proposed gas-line

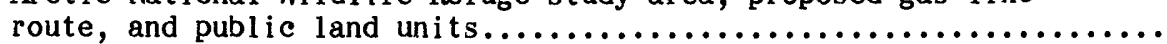

3. Locations of exploratory wells drilled in 1984 , oil and gas fields,

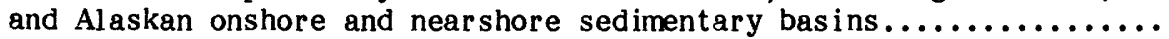

4. Areas of Federal, State, and industry activity for uranium,

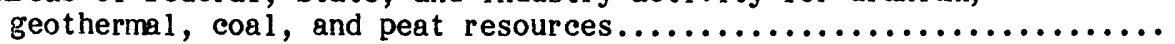

5. Locations of areas studied by the U.S. Geological Survey and

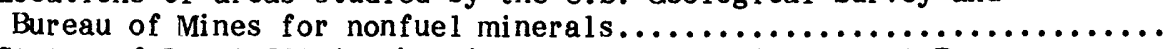

6. Status of Level III Alaska Mineral Resources Assessment Program

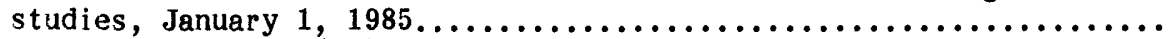

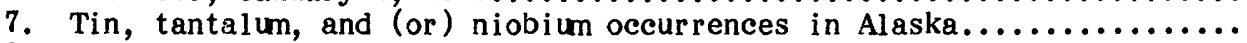

8. Areas of important industry activity for nonfuel minerals............

TABIES

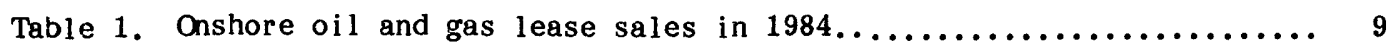

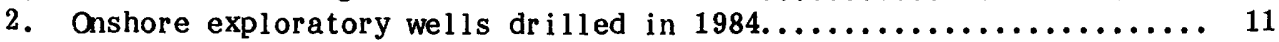

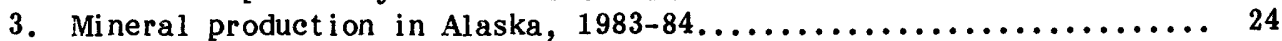

4. Abbreviated titles or brief descriptions of projects whose

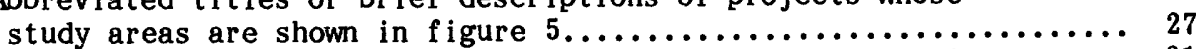

5. Summary of chromite deposits and est imated reserve potential........ 31

6. Occurrences, prospects, districts or areas containing tin,

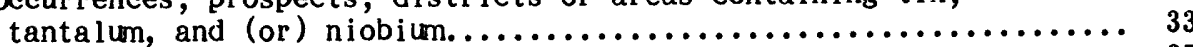

7. Areas of industry activity for nonfuel minerals............... 37 



\title{
1985 Annual Report on Alaska's Mineral Resources, As Mandated by Section 1011 of the Alaska National Interest Lands Conservation $f \mathrm{ct}$, Public Law 96-487, of December 2, 1980
}

\author{
Prepared by the U.S. Geological Survey, in cooperation with the Bureau of Mines, the Bureau of Land \\ Management, the National Park Service, the U.S. Fish and Wildife Service, the Department of \\ Agriculture-Forest Service, and the Department of Energy
}

\section{SUMMARY}

Section 1011 of the Alaska National Interest Lands Act (ANILCA) of 1980 requires that "On or before October 1,1982 , and annually thereafter, the President shall transmit to Congress all pertinent public information relating to minerals in Alaska gathered by the United States Geological Survey, Bureau of Mines, and any other Federal agency." This report was prepared in response to that requirement.

The Geological Survey and the Bureau of Mines are the principal Federal agencies that publish information about mineral resources in Alaska. Their reports and data are commonly used by other Federal agencies in making decisions about land use, access, environmental impacts, and claim evaluation. Most of the information in this circular has come from the Geological Survey and Bureau of Mines. Because of the time required for sample analysis, data synthesis, and publication, reports are generally issued a year or more after data and sample collection.

This circular is the fourth in the series of annual ANILCA reports. It provides information about projects current in, and events that occurred during 1984 and the first three months of 1985 . Sources of information include trade and professional journals, newspaper and magazine articles, talks at public meetings and hearings, press releases, as well as Federal and State publications.

This circular addresses onshore areas of Alaska only. Information is provided for energy resources and nonfuel minerals.

\section{OIL AND GAS}

Alaska continued to rank second among oilproducing States during 1984. The two petroleumproducing areas, the North Slope and Cook Inlet, provided a total of 631 million barrels of oil and natural gas liquids and nearly 200 billion cubic feet of dry gas. These totals represent increases of about 1 percent for oil and 1 percent for gas relative to 1983 totals. Alaska continues to provide about 20 percent of our national oil production.
Oil and gas activity in Alaska during 1984 involved the oil industry and State and Federal governments. Industry onshore exploration and development proceeded at a faster pace than in 1983. Exploration activity included geolorical and geophysical surveys and drilling of nine exploratory wells-seven on the North Slope, one in the Nenana basin of interior Alaska, and one in the Cook Inlet basin of southern Alaska. About 200 new production wells were drilled, mostly on the North Slcpe in the Prudhoe Bay and Kuparuk fields. Also on the North Slope, decisions were made to proceed with commercial development of three additional fields, and a pilot project was initiated to investizate the feasibility of commercial production from a multibillion-barrel heavy oil accumulation just west of the Prudhoe Bay field. In the Cook Inlet area, installation of a new enhanced oil recovery system was started on Alaska's first commercial oil field, the Swanson River, which began producing in 1959.

State and Federal agencies contint'ed their designated regulatory functions and conducted lease sales and surveys relating to land classification and oil and gas resource evaluation. Three competitive oil and gas lease sales were held in 1984--tv'o by the State of Alaska and one by the Federal Govornment. Companies and groups of investors bid a total of $\$ 35$ million for about 650,000 acres of land at these events.

Federal agencies continued to be active in the National Petroleum Reserve in Alaska in 1984. The Bureau of Land Management held its fourth competitive lease sale of Reserve land, and the Department of the Interior and the North Slope Borough reached agreement on the transfer of the Barrow gas fields to the borough.

Elsewhere in Alaska, Federal agencies continued the oil and gas programs reqi'ired by ANILCA. The U.S. Fish and Wildlife Service, Bureau of Land Management, and the U.S. Geological Survey pursued their studies of wildlife resources, wilderness characteristics, and oil and gas resources of the Arctic National Wildlife Refuge. 
For other National Wildlife Refuges in the State, a comprehensive review process was initiated in 1984 to identify areas where petroleum exploration or development activities would be compatible with the purposes of the refuge.

\section{URANIUM RESOURCES}

A slump in demand for uranium has created a surplus. As a result, there is little exploration activity nationwide. Alaska in particular faces potential high production costs, further reducing uranium-related work. The U.S. Geological Survey continued basic studies of uranium-bearing rocks in several parts of Alaska. The Department of Energy released a report describing the analyses for uranium and other elements in stream-sediment and water samples collected in the conterminous States and Alaska.

\section{GEOTHERMAL RESOURCES}

The Alaska Power Authority and its contractor carried out flow tests at the promising Makushin volcano geothermal field; several reports about that area were published in 1984. Geologists with the Alaska Division of Geological and Geophysical Surveys continued their studies in south-central Alaska, the Copper River basin, and on Adak Island. The U.S. Geological Survey's Geothermal Investigations program supported work on the Alaska Peninsula emphasizing examination of volcanoes that may have young, shallow magma chambers.

\section{COAL AND PEAT}

After several years of preparation, an Alaskan coal company began shipping coal to Korea under a long-term contract that calls for transporting $\mathbf{8 0 0 , 0 0 0}$ metric tons a year. Several other American firms and consortiums of foreign and American companies were in the process of making arrangements with Asian countries for coal export. Coalfield land offered by the State of Alaska was leased by a company planning a mine-mouth power generation plant in the Matanuska Valley, northeast of Anchorage. The towns of Seward and Cordova were actively building or planning coal transportation facilities.

The U.S. Geological Survey continued its studies of coal on the North Slope and near Anchorage. Interest during 1984 in potential Federal leases of coal lands remained low.

Peat production was reported to be about 125,000 cubic yards in 1984. Nearly all of this is for agricultural and greenhouse use. There was little government activity in peat studies.

\section{NONFUEL MINERALS}

The total value of mineral production in 1984 , $\$ 199.4$ million, was about $\$ 13$ million less than in 1983. This was primarily due to two factors: low prices for most commodities and a significant decrease in demand for sand and gravel. However, the outlook for Alaska's mineral industry is not as bleak as that for the rest of the United States. Gold production continued to increase, and three large mineral deposits moved still closer to production. However, the lack of infrastructure continues to hamper development of many promisiro deposits.

In 1983 , about 10,740 mineral claims were staked; in 1984 the number decressed to about 8,400. Similarly, exploration activity declined relative to 1983 . Nonetheless, the ampunt of money invested in preparations for mining increased in 1984.

State agencies were active in land-use planning and land classification, as well as in encouraging mineral-related projects. The Alaska Legislature was considering a major investment in infrastructure for the Red Dog zinc-lead-silver prospect. Throughout 1984, education about minerals was emphasized by several State programs. With the U.S. Geological Survey, the State established a center to store well core and samples from the entire State.

The U.S. Geological Survey's mineral resource assessment work continued at about the same level as in 1983. Three major new projects were started, and work drew toward completion for five projects. Studies of the Alaskan crust got under way in southern Alaska, and wilderness-area assessments were essentially completed.

The Bureau of Mines completed a study of mineral potential in the Denali Park area and several mining districts statewide. Working with State geologists, Bureau personnel undertook several studies of deposits of precious, critinal, and strategic minerals, particularly in southeastern Alaska.

At the Red Dog deposit, work continued on routing and construction of the access road, as well as on plans for the mine facilities. Questions of land status for an area near the Greens Creek zinclead deposit in southeastern Alaska remained unresolved, but a barge-loading dock was built and most permits for road constructicn have been obtained. A final environmental impret statement for the molybdenum mine projected for the Ketchikan area was near completion in late 1984.

Discoveries of several new precious metal lode deposits were announced, and several known deposits were being restudied. Whi o gold placer production continued to increase, even in the face of low gold prices, water quality has become a major issue. Several projects were delayed by legal challenges from environmental group and villages. The State prepared guidelines ant worked to develop a strategy to work with placer mining.

The demand for sand and gravel for drilling pad and road construction on the North Slope decreased dramatically in 1984, but the need for these commodities in urban construction continued to be strong. 


\section{Annual Report on Alaska's Mineral Resources}

\section{INTRODUCTION}

Section 1011 of the Alaska National Interest Lands Conservation Act (ANILCA) of 1980 requires that "On or before October 1, 1982, and annually thereafter, the President shall transmit to Congress all pertinent public information relating to minerals in Alaska gathered by the United States Geological Survey, Bureau of Mines, and any other Federal agency." The Geological Survey has been delegated the lead agency in responding to this requirement. This circular, the fourth in the series, is a synthesis of information made public in 1984 and early 1985.

This circular presents information about onshore areas of Alaska only; Outer Continental Shelf areas are not discussed. However, information about of fshore areas may have been used in studies of onshore mineral occurrences.

The Geological Survey and the Bureau of Mines are the principal Federal agencies that generate information about mineral resources in Alaska. Their data and reports are used by other agencies in making decisions about land use, access, environmental impacts, and, in some instances, claim evaluation. Therefore, the results of studies, projects, and programs of these two agencies form the greater part of the material in this circular. The Alaska Division of Geological and Geophysical Surveys has also contributed to parts of this report.

As used herein, the term "public information" includes published results of Federal projects as they appear in Government reports or in professional and trade journals. Additional sources are talks by representatives of Federal and State agencies and industry at symposia, conferences, and other public forums, as well as proceedings volumes, press releases, and newspaper and magazine articles.

The report is structured around two major types of resources: energy (oil, gas, uranium, geothermal, coal, and peat), and nonfuel minerals, including critical and strategic minerals. Although sand and gravel are economically very important in Alaska, they are not extensively discussed in this report.

The next several pages describe the roles of land-management and other Federal agencies as they relate to mineral resources. The distribution of ANILCA conservation units is shown in figure 1.

\section{DEPARTMENT OF INTERIOR U.S. GEOLOGICAL SURVEY}

The U.S. Geological Survey was established to conduct systematic investigations of the geologic structure and mineral resources of the Nation. The Survey carries out its mission through topographic mapping; geologic, geochemical, and geophysical studies; stream measurements; geohazards research; application of remote sensing techniques; and participation in multidisciplinary and interdepartmental studies and projects.

The Survey's role in assessing mineral resources has increased in the last few years, particularly in the area of energy resources. Field and laboratory research projects gather information about domestic petroleum, coal, uranium, and geothermal resources. In addition, Federal law requires that mineral assessments be made of areas to be set aside as wilderness and those established by ANILCA. The Alaska Mineral Resource Assessment Program (AMRAP, more fully described in the nonfuel minerals section of this circular) is an example of the Survey's response to this legislation. It has as its goal a systematic investigation of the State's resources. Begun in 1975, AMRAP examines mineral resources at four progressively more detailed levels of study in many parts of Alaska. Levels I and II are the most Jeneral and cover the largest areas. Studies at Level III draw on many geologic disciplines to produce areal resource maps at scales of $1: 250,000$ and $1: 125,000$. Nearly 30 Level III studies have been finished or are nearly complete. About 17 Level IV studies were under way in 1984; these are studies of individual mining districts, mineral deposits, or topics related to mineral deposit genesis. Products of such studies are used to help determine our national mineral and energy endowment and aid in analyzing potential hazards or impacts. These studies also help industry locate mineral deposits and assist in developing concepts, models, and techniques to identify nonfuel, critical, or strategic mineral deposits. Geological Survey publications are frequently used by industry as a source of information about mineral deposits in Alaska.

The Geological Survey carries on its work in Alaska through several programs, in addition to AMRAP. Among the programs active in 1984 were: (1) the Earthquake Hazards Reduction program, which seeks to mitigate earthquake losses through providing data and evaluations for land-use planning, engineering, and emergency preparations; (2) the Volcano Hazards program, an integrated study of hazards assessment, reduction, and prediction; (3) the Geologic Framework program, involving both basic and specialized research; (4) studies of mineral resources on public lands, especially those under study for wilderness status; (5) the Development of Assessment Techniques program, whose goal is improvement of the ability to identify and evaluate mineral resources; (6) the Critical and Strategic Minerals program that seeks to identify the potential of these resources to meet national military and economic needs; (7) the Sedimentary Basins program, which conducts studies of depositional, structural, diagenetic, and thermal processes so as to predict and evaluate water, 


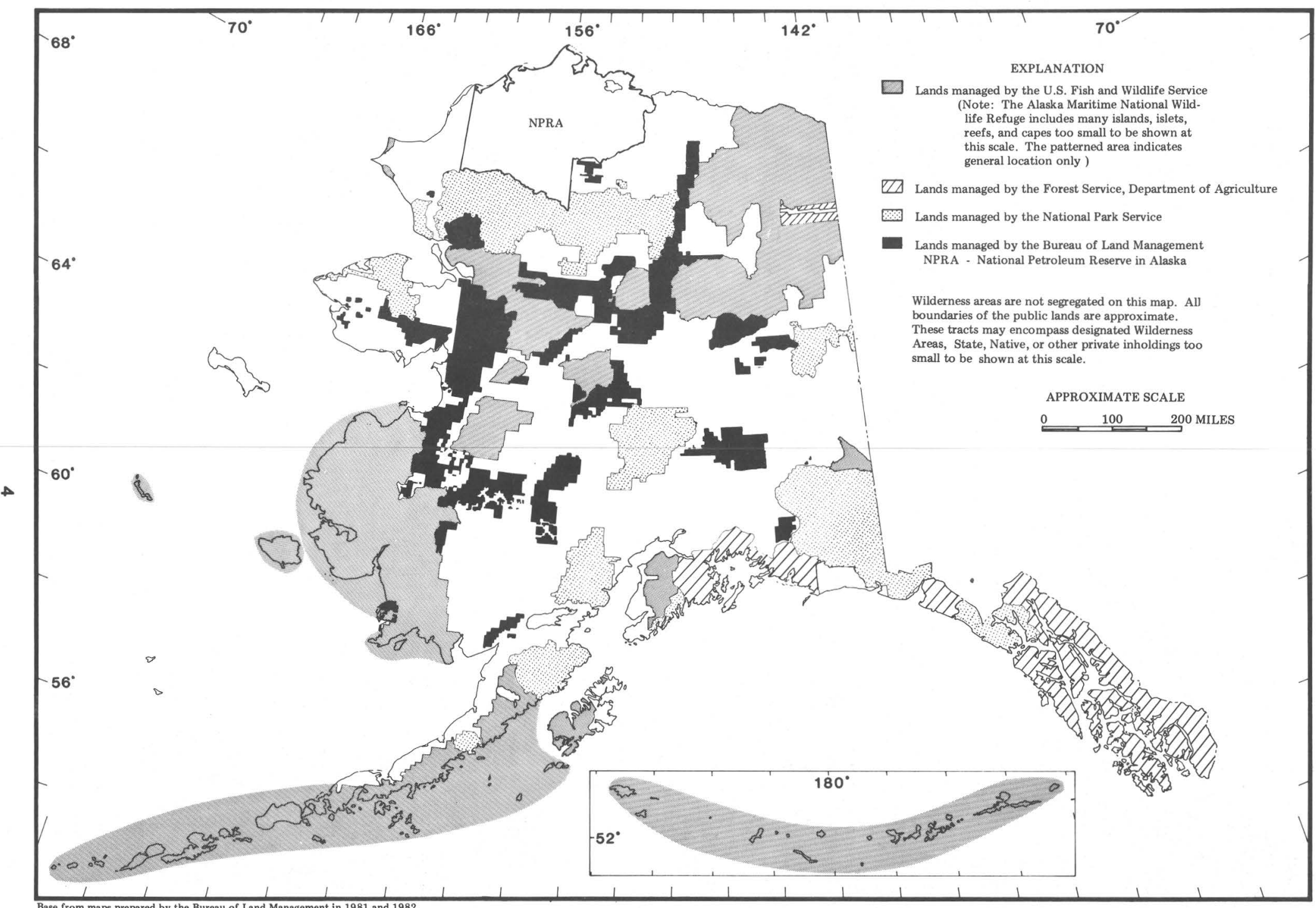

Figure 1.--Distribution of National Interest Lands and conservation units established by the Alaska National Interest Lands Conservation Act of 1980. Boundaries as of January 1, 1985. 
mineral, and hydrocarbon resources; (8) the Geothermal Investigations program, which is intended to improve understanding of the nature, distribution, and energy potential of these resources nationally; and (9) the Arctic Environmental Studies program, which is concerned primarily with engineering and environmental-geologic studies of transportation corridors and other areas of development, particularly those related to hydrocarbon and other mineral resources. Recently started is the Trans-Alaska Lithosphere Investigation and its project, the Trans-Alaska Crustal Transect, both of which seek to apply a multidisciplinary approach to studying the Earth's crust along a corridor from the Pacific Ocean to the Arctic Ocean. Many of these program activities are more fully described in later sections of this circular.

The Geological Survey is often the lead agency in the preparation of environmental impact statements for areas where mineral-related activity is proposed.

The Geological Survey's Branch of Alaskan Geology has its headquarters in Anchorage and a field of fice in Fairbanks. Other branch geologists are stationed in Menlo Park, Calif. Alaskan seismic observatories are maintained in Adak, Barrow, Fairbanks, and Sitka.

\section{BUREAU OF MINES}

The Bureau's mission is to help assure that the Nation's mineral supplies are adequate to maintain national security, economic growth, and employment. The Bureau of Mines is represented in Alaska by the Field Operations Center, with headquarters in Anchorage and offices in Juneau and Fairbanks. The Alaska Field Operations Center carries out its mission in six program areas:

(1) Minerals availability-This program is part of a worldwide Bureau of Mines program that relies on the Minerals Availability System (MAS) computer data base and the Mineral Industry Location System (MILS), a subset of MAS. MILS contains basic information about the identification and location of known mineral deposits. MAS is more extensive, containing information about reserve estimates, mineral extraction and beneficiation methodologies, environmental constraints to mining, and cost analyses for selected major mineral deposits. Data are obtained from private industry, Federal, State, and local agencies and Bureau programs. A complex computer and communications system allows the mineral information to be stored, manipulated, and retrieved. Data may be retrieved as computer-plotted map overlays and printouts of MAS/MILS data. Recently developed computer programs enable rapid and uniform develop- ment of cost data for MAS mineral deposit evaluations. Selection of MILS data for a given land area is enhanced by the ability to digitize boundary information directly from maps and compare the digitized boundaries with MILS locations. MAS and MILS mineral deposit data are cross-indexed to several other minerals information data bases.

Efforts for 1985 include publication of a MILS directory for Alaska, a project to evaluate subjective probabilistic resource estimation methodologies and their applicability to MAS, a project to predict remaining reserves of precious metals from past Alaskan producers, and computer, mining engineering, and economic evaluation support for the Bureau's ongoing mining district studies. Another project involves putting sample points and analytical results, principally from Bureau of Mines field projects into a computerized format that will make it possible to retrieve the basic data for future re-interpretation.

(2) Policy analysis-This relatively new prcoram of the Bureau of Mines in Alaska emphasizes the analyses of newly developed and existing mineral data to interpret their significance relative to local and national mineral needs. Such studies include comparing the cost of a company carro versus a company town in developing Alaska's mineral resources and the preparation of land status maps to provide basic data for an interpretation of the significance of the land open or closed to mineral development.

(3) Land assessinent-Section 1010 of ANILCA authorizes the Secretary of the Department of the Interior to assess the oil, gas, and other mineral potential of all public lands in the State of Alaska. A major Bureau of Mines program in Alaska is evaluating the mineral development potential of specific sites on Federal lands to aid Congress and land-nanaging agencies in making land-use decisions and to provide mineral data to the pul:ic.

During 1984, the Bureau of Mines embarked on a new long-range program to identify, study, and evaluate the mineral resources of all historic mining districts (as defined by the Bureau) in Alaska. The mining district studies are designed to complement the U.S. Geological Survey's mineral resource appraisal of Alaska lands (the AMRAP program described in previous paragraphs) and similar studies by Federal and State agencies. While the Geological Survey's AMRAP studies of 
mineral resources are commonly more regional in nature, the Bureau of Mines' studies will identify mineral reserves, their mineral character, metallurgy, and the economics of extraction and determine their significance relative to national and worldwide use and demand scenarios.

(4) Critical and strategic minerals-This statewide program supplements the mineral land assessment program. The Bureau of Mines investigates critical and strategic mineral deposits on Federal land closed to mineral entry by industry, as well as deposits open to entry if they are not of current interest to private industry. Cooperative efforts with industry also have been undertaken. In addition to locating deposits and estimating size and grade, the Bureau takes bulk samples for metallurgical research to estimate recoverability and extraction costs. These investigations should identify a stockpile in the ground that can be used when needed.

(5) Mining research-Mining research is directly related to the mineral land assessment and the critical and strategic minerals programs. Various Bureau of Mines and university research centers cooperate with the Alaska Field Operations Center to solve mineral utilization problems. The Bureau has a continuing metallurgical research program concerned with critical and strategic minerals. Recent studies focused on tin-bearing minerals on the Seward Peninsula, potential chromiumbearing material in south-central Alaska, and on potential cobalt, nickel, and platinum-group metals in southeastern Alaska. A cooperative program with the University of Alaska is concerned with underground placer mining methods. In addition, the Bureau of Mines and the University of Alaska have for many years participated in the maintenance and use of a permafrost research center at Fox, near Fairbanks, in cooperation with the Corps of Engineers Cold Regions Research and Engineering Laboratory.

(6) State minerals specialist-This program provides coverage of mineral activities in Alaska and assists in developing and releasing nonfuel minerals industry information. It serves as a liaison between the Bureau, the State of Alaska, the mineral industry, and the general public.

\section{BUREAU OF LAND MANAGEMENT}

The Bureau of Land Management is responsible for multiple-use management of the surface and subsurface of 23 million acres of the National Petroleum Reserve in Alaska, 600,00C acres of the Central Arctic Management Area, ard approxi mately 76 million acres of public lands south of Alaska's North Slope (fig. 1). The last figure includes substantial acreage encumbered through State and Native selections. Add tionally, the Bureau of Land Management admiristers geothermal resources and leasable and locatable minerals on other Federal lands, including acquired lands, and on private lands where the Federal Government has retained mineral rights.

In May of 1984, the Bureau of J,and Management revised its mineral resources pol:cy statement to reflect the Bureau's continuing commitment to encourage private enterprise in the development of domestic minerals, consistent with the need for these resources. Public lands are generally to remain open to environmentally sisund mineral exploration and development. Land use planning will reflect energy and mineral velues through geologic assessments. To reinforce the Bureau's mineral resource policy, the secretary of the Interior, in December 1982, merged the onshore mineral and energy functions of the Minerals Management Service into the Bureau of Land Management. The result is a strorger minerals organization with significant rest-ucturing of National, State, and district offices. The new organization has offices for fluid minerals (oil and gas, geothermal resources, and resnurce evaluations), for solid minerals (coal, oil shale, tar sand, and nonenergy leasable minerals), and for mining law and mineral assessment.

The Bureau of Land Management's administrative responsibilities for minerals require close coordination with other surface management agencies. Generally, in the case of upland or onshore leases, the Bureau of Land Management issues leases and integrates the leasing with other land uses in cooperation with the surface management agency. After a lease is issued, the newly integrated mineral function of the Btreau assumes jurisdiction of exploratory and development activities in cooperation with the land manager to assure surface protection. The Bureal continues to develop a schedule for analysis to determine which lands not on the North Slope should $t ?$ opened for mineral leasing.

The principal activities of the B dreau of Land Management that are related to Alaska's minerals and energy resources are (1) preparntion for the scheduling of Federal oil and gas leases in the upland areas with the concurrence of the surface management agency, (2) organization $\varepsilon$ nd evaluation of Federal oil and gas leases, and (3) recording of mining claims and determinations of the validity of mining claims for mineral patents. In the past, the Bureau of Land Management has rarely produced reports that pertain to the evaluation of mineral and energy resources; with the Minerals Manage- 
ment Service (onshore) merger, the Bureau will be releasing reports about onshore mineral potential, generally in connection with land openings made under A NILCA provisions.

The Bureau of Land Management is responsible for enforcing the environmental and technical stipulations of the Agreement and Grant of Right of Way for the Trans-Alaska Pipeline System. The overall goal is to maintain a continuous supply of energy with minimal environmental impact. The Bureau is also charged with issuing land-use authorizations and conducting mineral and material sales to support preconstruction activities for the planned natural gas pipeline and other projects.

\section{NATIONAL PARK SERVICE}

The act establishing the National Park Service in 1916 (39 Stat 535) directed it to $1 * * *$ consider the scenery and natural and historical objects and the wildlife $e^{* * *}$ and to provide for enjoyment of the same in such a manner and by such means as will leave them unimpaired for the enjoyment of future generations." Administrative policy is based on the principles of maintenance of the natural resources and on the concept that national interest dictates decisions affecting private or public enterprise in the parks. The Service currently has jurisdiction over an estimated 52 million acres in Alaska (fig. 1). Its main Alaskan office is in Anchorage.

The Park Service's responsibility for mining claims and mining on park lands in Alaska and elsewhere is basically limited to mineral examinations and determinations of valid existing rights, environmental assessments of the potential impacts of mining on natural and cultural resources on Federal or other lands, protection of park resources through mining plans developed under Federal regulations, and approval of mining plans of operation. The assessments and mining plans are available for public review.

Except for validity determinations, the Service rarely collects or publishes basic data about mineral deposits, commonly relying on information gathered by claimants, the U.S. Geological Survey, the Bureau of Mines, or State or private sources. Validity determinations also involve the Bureau of Land Management and the Office of Appeals and Hearings. Results of mineral examinations are made public when decisions are final.

\section{U.S. FISH AND WILDLIFE SERVICE}

The mission of the Fish and Wildlife Service is to provide Federal leadership to conserve, protect, and enhance fish and wildlife and their habitats for the continuing benefit of people. In Alaska, the Service seeks to accomplish this mission through a variety of programs that implement the provisions of the Endangered Species Act, Marine Mammals Protection Act, Fish and Wildlife Coordination Act, Rivers and Harbors Act, National Wildlife Refuge System Administration Act, various migratory bird laws, and other statutes. Direct activities under these laws include administration of 77 million acres of National Wildlife Refuges (NWR), fish and wildlife research, law enforcement, ant habitat protection through agency review of and comments on permit requests, environmental impact statements, and other items.

Under ANILCA, 16 refuges (fig. 1) were created or enlarged to conserve fish ant wildlife populations and their habitats, as well as other values. Except for valid rights existing at the time of establishment, these refuges are closed to entry and location under mining laws. The refuges are open to entry under leasing laws; however, they are closed to mining of Federal coal by the Federal Coal Leasing Amnend nents Act of 1975 and closed to geothermal resource leasing by the Geothermal Steam Act of 1970 .

While many traditional activities rave been deemed appropriate for these refuges, other uses, including oil and gas leasing, will be permitted only when such activities are compatible with the purposes for which the refuges were established. The compatible uses will be determined through the Comprehensive Conservation Planning process currently under way for several Alaskan rexions.

Pursuant to Section 204(c) of the Federal Land Policy and Management Act, in 1984 a report was prepared on the mineral potential of 325,000 acres intended for withdrawal and addition to the Arctic NWR (U.S. Fish and Wildlife Service, 1984, listed with the agency's reports at the back of this circular). The acreage is a narrow strip across Coleen and Sheenjek Rivers and is surro'inded by exisiting refuge boundaries and the Canadian border. In the Alaska Maritime NWR, a temporary exchange of 4,110 acres with Cook Inlet Region, Inc. (CIRI), on St. Matthew Island was ruled illegal by U.S. District Court; CIRI has appealed the ruling. CIRI planned to use the land for ar airstrip, camp, and refueling station during oil and gas exploration in the Navarin Basin, which is $\mathbf{1 5 0}$ miles from St. Matthew Island, but more than 400 miles from Nome, the nearest established port.

\section{DEPARTMENT OF AGRICULTUPE}

\section{FOREST SERVICE}

The mission of the Forest Service of the Department of Agriculture is to provide a continuing flow of natural resource goods, including mineral and energy resources, and services to help meet National needs and contribute to meeting such needs worldwide. The Forest Service's responsibility in regard to these resources is to encourage and support environmentally sound miner 9 enterprises on Federal lands under its jurisdiction, consistent with other surface resource values. Under authority of the Forest Service Org nnic Act, the Forest Service administers regulation for the protection of surface resources from activities 
concerned with locatable minerals. In managing the use of these resources, it is the objective of the Forest Service that adverse environmental impacts to surface and cultural features and values that might result from lawful prospecting operations be minimized or repaired. This is accomplished through the use of reasonable conditions that do not interfere with legitimate, well-planned mineral operations. The Forest Service provides research information and technology to help with postmining reclamation. Annually, the Forest Service in Alaska provides for the disposal of millions of tons of sand, gravel, and stone.

Under a Memorandum of Understanding with the Bureau of Land Management, the Forest Service provides joint admininstration of the general mining laws on Forest Service lands. An example of this joint responsibility is the patent issued to the U.S. Borax Company for mining claims at their Quartz Hill deposit. The Forest Service recommended issuance of this patent based on favorable findings in the mineral report prepared by Forest Service mineral examiners.

The Forest Service cooperates with the Department of the Interior agencies, particularly the Bureau of Land Management, in issuing mineral leases and assuring mitigation of surface impacts of such activities. The Forest Service also cooperates with the State of Alaska and private sectors in development of energy and mineral resources on inholdings. One such inholding is the Bering River coal field, under consideration for possible development by Chugach Natives, Inc., and others in a consortium.

The Alaska region of the Forest Service encompasses about 23 million acres (fig. 1). The Service's regional office is in Juneau. Offices for the Chugach Forest are in Anchorage, and for the Tongass Forest, in Juneau, Sitka, Ketchikan, and Petersburg.

\section{DEPARTMENT OF ENERGY}

The functions of the Department of Energy in Alaska are primarily in the areas of (1) administering the current petroleum acts and Congressional mandates relating to energy, (2) monitoring grants, and (3) overseeing contracts for studies of geothermal and uranium energy resources that are described in this report. Most current activity is coordinated with the Federal Energy Regulatory Commission. The Department maintains a field office in Anchorage.

The Energy Department's National Uranium Resource Evaluation (NURE) program, formerly active in Alaska, has been terminated. All nonproprietary geoscience data, including drill core and cuttings and stream-sediment samples, from this program are being transferred to the U.S. Geological Survey. However, proprietary information about reserves or production are being retained by the Department's Energy Information Admininstration. Inspection of cores and cuttings can be arranged through T. C. Michalski, U.S. Geological Survey, MS 975, P.O. Box 25946, Denver Federal Center, Denver, CO 80225. Information about the samples can be obtained through $B$. R. Burger, MS 973 at that address.

Few Department reports dealinp only with Alaska were released in 1984. Thes? titles and information about obtaining NURE reports are given in the references section under the Department of Energy heading.

\section{CONTACTS FOR FURTHER INFORMATION}

Department of the Interior

Bureau of Land Management

Michael Penfolf. State Director Federal Buildirg 701 C Street, Rox 13

Anchorage, AK 99513

Bureau of Mines Donald P. Blasko, Chief Alaska Field O-arations Center

Suite 101

201 East 9th Avenue

Anchorage, AK 99501

U.S. Fish and Wildlife Service

Robert Gilmor ?, Regional Direntor

1011 East Tudor Road

Anchorage, AK 99503-6119

U.S. Geological Survey

Donald Grybeck, Chief

Branch of Alaskan Geology

4200 University Drive

Anchorage, AF 99508-4667

National Park Service

Roger Contor, Regional Director Alaska Regional Office 2525 Gambell Street Anchorage, AF 99503-2892

Department of Agriculture Forest Service

Michael Barton, Regional For ?ster Alaska Region P.O. Box 1628 Juneau, AK 9.9802

\section{Department of Energy}

Fred Chiei,
Regional Represen-
tative
Federal Building
$701 \mathrm{C}$ Street
Anchorage, AY 99513




\section{OIL AND GAS}

In 1984 , as in the previous several years, oil and gas were the most valuable commodities produced in Alaska. Just how important these commodities are to the State and its residents is shown in a study sponsored by the Alaska Oil and Gas Association. Eighty-five percent of the State's revenues come from taxes, rents, and royalties paid by the oil companies, and more than a fourth of all Alaskan households have at least one member employed by an oil company or oil service company (Anchorage Daily News, Dec. 11, 1984).

Alaska's two oil-producing areas, the Arctic North Slope and the Cook Inlet, provided a total of nearly 631 million (42-gallon) barrels of oil and natural gas liquids, 200 billion cubic feet of dry natural gas, and 1 trillion cubic feet of casinghead gas in 1984. This represents an increase over 1983 of about 1 percent for oil and natural gas liquids and 1 percent for dry gas (Alaska Oil and Gas Conservation Commission, 1985, listed with references cited at the end of this section). Production increases on the North Slope leases of fset production declines from the Cook Inlet area. Production in the latter area is currently declining at a rate of 10 to 15 percent per year (Alaska Journal of Commerce and Pacific Rim Reporter, Oct. 15, 1984). The daily rate of oil and natural gas liquids production from the entire State of Alaska at the end of 1984 amounted to 1.72 million barrels, or about 20 percent of the United States daily production.

During 1984, Federal and State agencies conducted three onshore competitive oil and gas lease sales, monitored and supervised lease development, collected rent on leases and royalties on production, and conducted numerous geologic and geophysical studies relating to oil and gas resource evaluation and land classification. A major program is under way in the Aretic National Wildlife Refuge. Most of these studies are only briefly reported in this circular; for Federal studies, the reader is directed to the selected references listed at the back of this circular, and for State activities, the State of Alaska quarterly report, "Alasta Mines and Geology."

At competitive lease sales, a tistal of $\$ 34.6$ million in high bids was offered to acquire about 637,000 acres for future exp]ration. Information about the lease sales is summarized in table 1, and the lease sale areas are shown in figure 2. The terms of the Federal leanes are described in the following section about the Bureau of Land Management's activities. The terms of the State leases can be obtained from the Lease Administration Office, Alaska Department of Natural Resources, 555 Cordova Street, Anchorage, AK 99501.

Industry activity for onshore Alaska in 1984 included geophysical and geological surveys and drilling of 9 exploratory wells (table 2, fig. 3) and about 200 development wells. Development drilling was concentrated primarily on the North Slope in two producing and several developing fields.

\section{ACTIVITY BY FEDERAL AGENCIES}

Bureau of Land Management.-The Bureau of Land Management is responsible for all mineral le ssing of public domain or acquired lands, regardless $\mathrm{c} f$ which Federal agency is designated as surface manager. This includes determinations of fair market value based on analysis of all available geclogical, geophysical, engineering, and economic d $\varepsilon$ ta. It also includes responsibility for inspection and enforcement actions on exploration and cevelopment operations on leased areas.

The Bureau in Alaska has an automated filing and recordating system for locatable and leasable minerals. As a consequence, all filings are now entered into the Alaska Automated Land Records System (AALRS). A computer-generated abstract is available in the Alaska State Office in Anchorage and in the Anchorage and Fairbanks District Offices. The file includes a history of actiors and a complete description of the land applied for in an oil and gas offer to lease, lands rejected, and the lands under lease, as well as other information.

Table 1.-Onshore oil and gas lease sales in 1984; locations of leased areas shown in figure 2

\begin{tabular}{|c|c|c|c|c|c|}
\hline $\begin{array}{l}\text { Area } \\
\text { no. }\end{array}$ & Sale and number & $\begin{array}{l}\text { Sale } \\
\text { date }\end{array}$ & $\begin{array}{r}\text { Acreage } \\
\text { of fered } \\
(x \quad 1000) \\
\end{array}$ & $\begin{array}{l}\text { Acreage } \\
\text { bid on } \\
(\mathrm{x} 1000) \\
\end{array}$ & $\begin{array}{l}\text { Total high } \\
\text { bids (millions } \\
\text { of dollars) } \\
\end{array}$ \\
\hline 1 & $\begin{array}{l}\text { Beaufort Sea }{ }^{1} \text { and North } \\
\text { Slope Uplands, No. } 43 \text { and } 43 A^{2}\end{array}$ & $5 / 22$ & 375 & 358 & 33.8 \\
\hline $\begin{array}{l}2 \\
3\end{array}$ & $\begin{array}{l}\text { NPRA, No. } 841^{3} \\
\text { Alaska Peninsula, No. } 41^{2}\end{array}$ & $\begin{array}{l}7 / 18 \\
9 / 17\end{array}$ & $\begin{array}{l}1,591 \\
1,440\end{array}$ & $\begin{array}{r}0 \\
279\end{array}$ & $\begin{array}{l}0 \\
0.84\end{array}$ \\
\hline
\end{tabular}




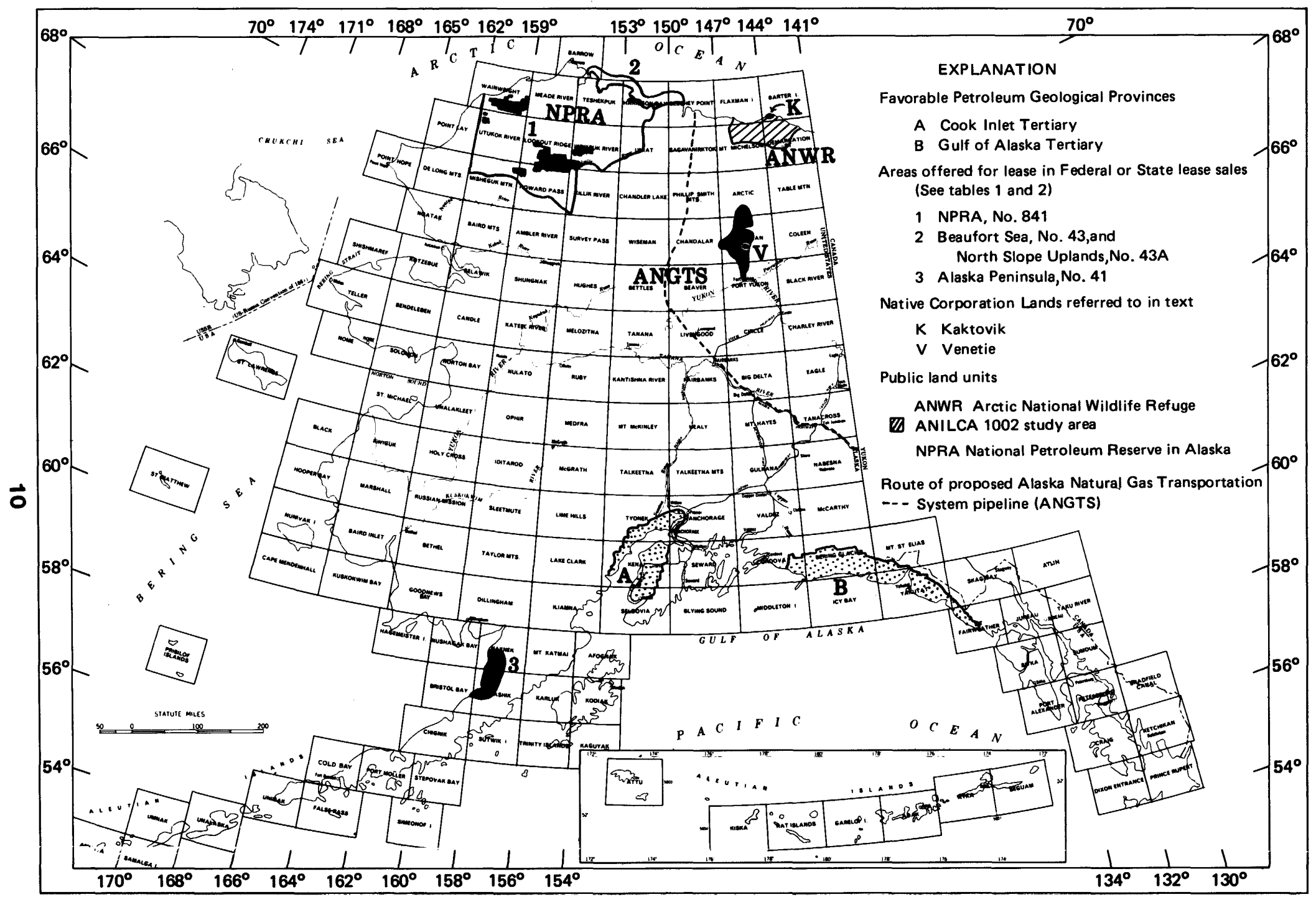

Figure 2.-Favorable Petroleum Geologic Provinces, areas offered for lease, Arctic National Wildlife Refuge study area, proposed gas-line route, and public land units. 
Table 2.-Onshore exploratory test wells drilled in 1984; locations shown in figure 3

\begin{tabular}{|c|c|c|c|c|c|}
\hline $\begin{array}{l}\text { Well } \\
\text { no. }\end{array}$ & $\begin{array}{l}\text { Company, } \\
\text { well name }\end{array}$ & $\begin{array}{l}\text { Location } \\
\text { (township- } \\
\text { range- } \\
\text { section) }\end{array}$ & $\begin{array}{l}\text { Total } \\
\text { depth } \\
\text { (in feet) }\end{array}$ & $\begin{array}{c}\text { Date } \\
\text { completed }\end{array}$ & Remarks \\
\hline \multicolumn{6}{|c|}{ North Slope (Umiat meridian) } \\
\hline $\begin{array}{l}1 \\
2 \\
3 \\
4 \\
5 \\
6 \\
7\end{array}$ & $\begin{array}{l}\text { AROO 1, Hemi Spr ings State } \\
\text { Union 1, E de K Leff ingwell } \\
\text { Exxon J-1, Alaska State } \\
\text { Soh io 6, Sag Del ta } \\
\text { AROO 1, PBU South Bay State } \\
\text { AROO 2, Ol iktok Point } \\
\text { AROO 2A, Ol iktok Point }\end{array}$ & $\begin{array}{l}10 \mathrm{~N}-11 \mathrm{E}-12 \\
8 \mathrm{~N}-22 \mathrm{E}-25 \\
6 \mathrm{~N}-22 \mathrm{E}-23 \\
11 \mathrm{~N}-15 \mathrm{E}-2 \\
11 \mathrm{~N}-15 \mathrm{E}-22 \\
13 \mathrm{~N}-9 \mathrm{E}-9 \\
13 \mathrm{~N}-9 \mathrm{E}-9\end{array}$ & $\begin{array}{r}10,937 \\
14,824 \\
13,644 \\
10,980 \\
9,700 \\
8,260 \\
9,750\end{array}$ & $\begin{array}{l}4 / 3 \\
8 / 12 \\
6 / 19 \\
5 / 18 \\
1 / 9 \\
5 / 5 \\
5 / 18\end{array}$ & $\begin{array}{l}\text { suspended } \\
\text { P/A } \\
\text { P/A } \\
\text { suspended } \\
\text { suspended } \\
\text { suspended } \\
\text { P/A }\end{array}$ \\
\hline
\end{tabular}

Cook Inlet (Seward meridian)

8 AROO/CIRI 1, Funny River 4N-10W-23 18,009 $3 / 17 \quad$ P/A

Interior Alaska (Fairbanks meridian)

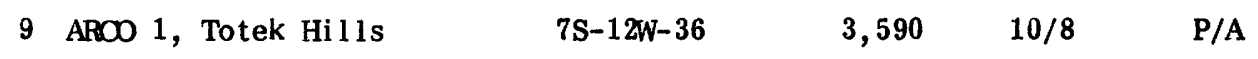

1 Plugged and abandoned

A Memorandum of Understanding involving the Governor of Alaska, the Bureau of Land Management, the Regional Forester of the Department of Agriculture, and the Undersecretary of the Interior Department was signed in May 1982. The memorandum established a mutually approved schedule to study areas prior to oil and gas lease offerings and identified key contacts in the State and Federal offices to facilitate exchange of information and review. It also confirmed a commitment to cooperate on land-use planning.

Under terms of a June 1983 Memorandum of Understanding among the Bureau, the Geological Survey, and the U.S. Fish and Wildlife Service regarding the resource assessment of the Arctic National Wildlife Range, the Bureau's responsibilites include the following: (1) The Bureau will provide two technical experts knowledgeable on all aspects of geological and geophysical exploration practices to serve on the interagency panel for reviewing the technical accuracy of the industry exploration proposals; (2) the Bureau will, if necessary, provide technically qualified field monitors to accompany industry crews to assure the quality of the geological and geophysical data acquired by the permitees; (3) the Bureau will receive from the Fish and Wildlife Service all oil and gas resource data generated by the industry programs and will assume responsibility for its storage, handling, and security; (4) the Bureau will interpret and analyze all available geologic, geophysical, engineering, and economic data in order to provide the Fish and Wildlife
Service with information needed to comf'ete the assessinents indentified in ANILCA Section $1002(\mathrm{~h})$ (1), (4), (5), and (6); and (5) the Bureau will $\varepsilon$ ssist the Fish and Wildlife Service in preparing appropriate sections of the mandated report by the Secretary of the Interior to Congress. Most of the work required of the Bureau by this memorandum will occur in 1985 and 1986, as part of its assistance to the Fish and Wildlife Service. Further information about the assessment is given in the section descriting U.S. Fish and Wildlife Service activities.

In establishing and implementing an oil and gas leasing program as required by Section 1008 of ANILCA, the Bureau of Land Management has conducted noncompetitive lease offerings in three areas south of 680 north. The Minchumina area was opened in 1981, the Denali-Tiekel area in 1982, and the Seward Peninsula in September 1983. As of October 1984, about 248,000 acres of the Minchumina area, 2.5 million acres of the Denali-Tiekel area, and 650,000 acres in the Seward F ninsula area were under lease.

A lease sale in the NPRA, the fourth in the series, conducted in July 1984 received no b: is. The lack of interest in this sale is thought to be the result of several factors: litigation of the previous NPRA sale by two North Slope Natives on the subssistence issue, no drilling on the first three sale areas that could have provided informetion on prospects in the area, and a downturn in the oil market, along with continued high operating costs. Terms of the Federal leases were similar to those 


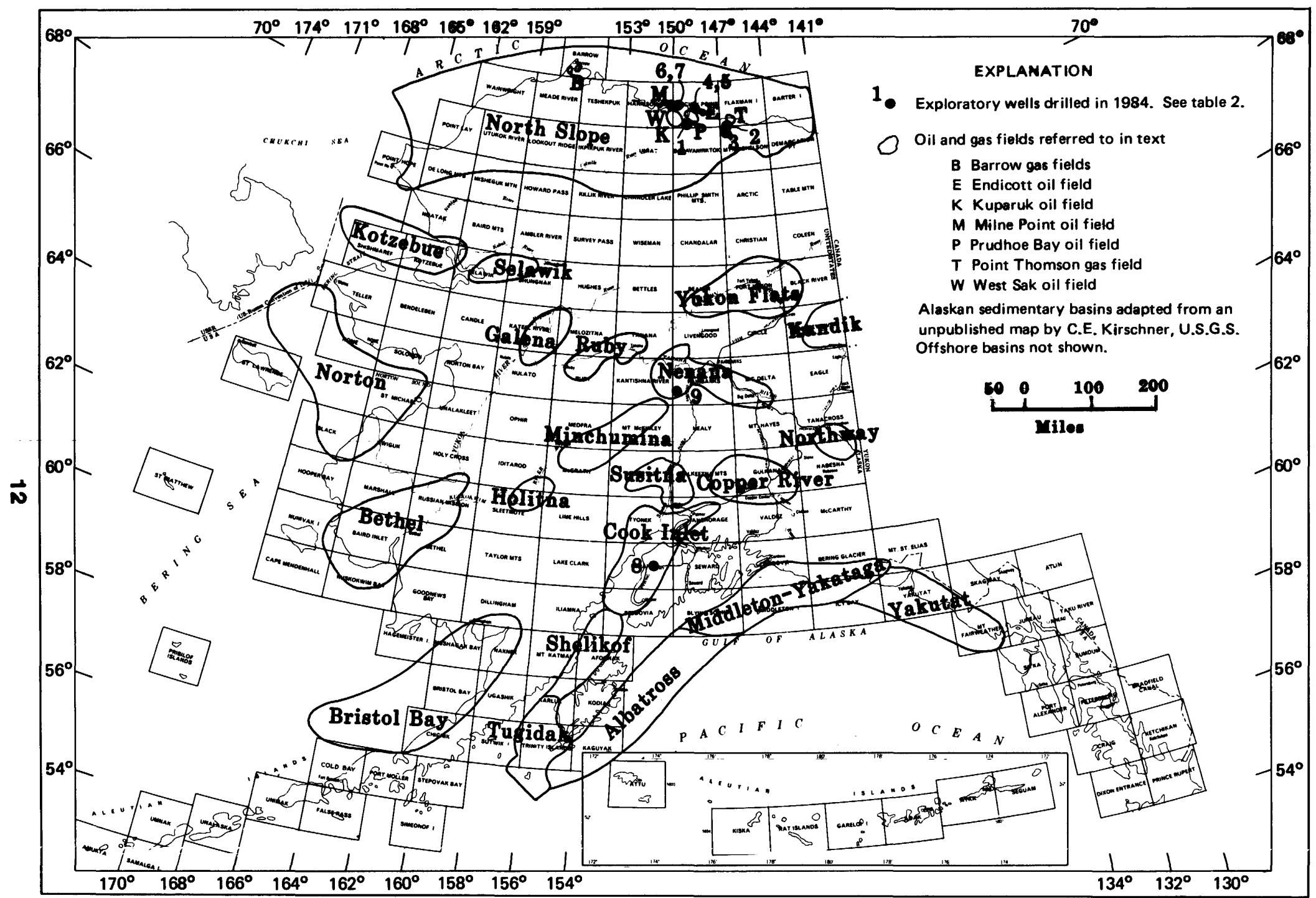

Figure 3.--Locations of exploratory wells drilled in 1984, oil and gas fields, and Alaskan onshore and nearshore sedimentary basins. 
offered in previous years-a royalty rate of 16 $2 / 3$ percent with a cash bonus. The litigation of the third NPRA lease sale has since been settled, and one leaseholder, ARCO Alaska, Inc., planned to drill an exploratory well early in 1985 .

The Bureau is transferring lands in the "utility corridor" between the Yukon River and Washington Creek to the State of Alaska. The State has requested that the rest of the lands in the corridor, those south of the North Slope Borough boundary, be made available for its selection under terms of the Statehood act. The Bureau is reviewing this request.

The Annual Report of the Bureau's Branch of Pipeline Monitoring is available through the Public Affairs Office in the Anchorage Eederal Building. The Branch, which assures that terms and conditions of the Alyeska Pipeline Service Company's land use agreement are met, is part of the Bureau's Division of Mineral Resources.

The Northwest Alaskan Pipeline Company, which proposes to build a natural gas pipeline from Prudhoe Bay through Canada to the conterminous United States (fig. 2), has again delayed its schedule of activity; during 1984, the company lost some financial support. As a result, the Bureau's involvement with this project was at a low level. The Yukon Pacific Corporation has submitted a right-of-way application to the Bureau of Land Management for a gas pipeline from Prudhoe Bay to tidewater near Kenai. The Bureau has responsibility for processing this application. The viability of these pipeline projects is linked to demand and price, worldwide, for natural gas.

U.S. Fish and Wildlife Service.-The mission and primary efforts of the Fish and Wildlife Service are aimed at the protection and conservation of fish, wildlife, and their habitats. The Fish and Wildlife Service is responsible for the administration of 16 National Wildlife Refuges in Alaska (totaling more than 77 million acres). The Service also cooperates with all State and Federal agencies to protect and conserve wildlife on the remaining 80 percent of Alaska. Any oil- and gas-related activities on refuges are subject to restrictions and protective stipulations developed by the Service.

On the Kenai National Wildlife Refuge (NWR) in 1984, diminishing amounts of oil continued to be produced from Alaska's first commercial oil field, Swanson River, while gas production increased from the Beaver Creek field. ARCO Alaska, Inc., concluded a deep well test at Funny River and completed another deep well by angle drilling from the Wolf Lake No. 2 pad. Both wells were abandoned. These are the last in a three-well exploration agreement between ARCO and the Cook Inlet regional Native corporation on Fish and Wildlife Service-conveyed subsurface property; the Service manages the surface of these lands.

Exploration-related surface activities on the Arctic NWR coastal plain took place under Fish and
Wildlife Service surveillance in accordance with Section 1002 of ANILCA. That section mandates that an assessment be made of the fish ant wildlife resources of the coastal plain of the Arctic NWR and the potential impacts of oil and gas exploration, development, and production. Accordingly, the act authorized a baseline study [Section 1002 (c)] of biological and human resources and, in Section 1002 $(d-g)$, called for limited petroleum exploration of the refuge's coastal plain. Exploration is to consist of surface geological and geophysical studies only; exploratory drilling is not permitted. The exploration program allows private industry to gather data about the petroleum potential of the area. These data also must be submitted to the Department of the Interior for analysis. The assessment of the oil and gas resources of the coastal plain will ka part of a report to Congress to be submitted not later than September 2, 1986. Congress will then decide whether further exploration and development should be allowed on the refuge.

The Fish and Wildlife Service is the overall coordinator of the Section 1002 resource assessment. The agency has entered into a three-way Memorandum of Understanding with the Fireau of Land Management and the U.S. Geologicel Survey (June 1983); these agencies have the technical responsibility for determining the oil and gas potential of the refuge. Further information about the role of other Federal agencies is given in the previous sections describing their activites.

In accordance with Fish and Wildlife Service regulations promulgated in 1983, a limited amount of exploration was allowed on the coastal plain of the Arctic NWR in 1984. Several comparies were permitted to conduct surface geological exploration. To minimize adverse environmental impacts associated with seismic exploration in arctic areas, the Fish and Wildlife Service: (1) allowed only one permittee to conduct seismic exploration; (2) placed full-time field monitors with each of the permitee's seismic crews, and (3) allowed only that amount of seismic work believed necessary to prepare the required report to Congress. Geophysical Service Inc., as the sole permittee, collected 607 line miles of seismic data.

After the first season of seismic work was completed, the Fish and Wildlife Service determined that significant adverse impacts to fish, wildlife, and other resources had not occurred. In December 1984 , the Service announced that a second season of seismic exploration (not to exceed 580 liro miles) would be allowed during 1985 . The Service believes that the additional seismic work is necersary to fully assess the oil and gas potential of the area and to produce the Congressional report.

Section 1008 of ANILCA provides fo" oil and gas exploration on refuges in Alaska. During 1984, special-use permits were issued for surface geological work on the Alaska Maritime, Alaska Peninsula, Arctic, Becharof, Izembek, Togiak, and 
Yukon Flats NWRs. Copies of data resulting from geological and geophysical exploration are now required to be submitted to the Fish and Wildlife Service. Under an agreement begun in 1984 with the Bureau of Land Management, the data are transmitted to that agency for secure storage. The data submitted by permitees will be used in future land management decisions. Bonds at $\$ 10,000$ are now required with permits.

Section 1008 of ANILCA also calls for establishing an oil and gas leasing program for lands south of latitude $68^{\circ}$ north, pursuant to the Mineral Leasing Act of 1920 as amended. This program does not apply to NWRs where the Secretary of the Interior, after considering the national interest in these resources, determines that exploration or development of petroleum resources would be incompatible with the purposes of the refuge. Section $304(\mathrm{~g})$ of ANILCA cites the comprehensive conservation planning process as a means of identifying parts of NWRs where petroleum leasing or other activities may be compatible.

During 1984, the Comprehensive Conservation Planning process began on the Kanuti, Koyukuk, Nowitna, and Yukon Delta NWRs. In the process, defining the limits of the study and the form and content of the report and collection of related data are the first steps; following this, alternatives are drawn up. Then the draft plans are released for a 90-day period of public review. Draft releases are scheduled for 1985 on the Kanuti, 1986 on the Koyukuk and Nowitna, and 1987 on the Yukon Delta NWRs. Nearing completion was planning on the Kenai NWR, where about 100,000 acres in the Chickaloon Flats area is recommended for closure to oil and gas leasing. Planning continued on the Alaska Peninsula, Becharof, Izembek, Kodiak, Tetlin, Togiak, and Yukon Flats NWRs, and also, without State participation in the former Bristol Bay Cooperative Management Plan, on a regional plan for the Alaska Peninsula, Becharof, Izembek, and Togiak NWRs. Individual refuge plan drafts were released for Alaska Peninsula, Becharof, and Izembek NWRs. (See the references listed for the Fish and Wildlife Service at the back of this circular.) For the Alaska Peninsula, the Fish and Wildlife Service proposes wilderness status for 84 percent of the refuge lands and oil and gas exploration for the remainder-around and near Herendeen Bay, Port Moller, Sandy Lake, and Ugashik Lakes. For the Becharof NWR, the preferred alternative in the draft plan includes about 400,000 acres proposed as wilderness land north and south of Becharof Lake, adjacent to existing wilderness. Northwest of the lake, no wilderness is proposed, and geophysical exploration would be allowed on a case by case basis. On the Izembek NWR, 95 percent of the refuge is now wilderness, and the preferred alternative in the draft plan calls for no leasing for the remainder.
If refuge lands are to be leased $t y$ the Bureau of Land Management, such leases will be competitive if located in a Favorable Petroleum Geologic Province (fig. 2) or noncompetitive if not so located. All leasing, exploration, $\mathrm{cr}$ production would be subject to permits and stipulations designed to protect fish, wildlife, and local subsistence activities and to National Environmental Policy Act regulations.

On State lands around the Prudhoe Bay and Kuparuk oil fields, between the Colville and Canning Rivers, Fish and Wildlife Service activities include review of Corps of Engireers permit applications under Section 404 of the Clean Water Act. Fish and Wildlife Service recommendations are often adopted by the Corps of Figineers and result in the avoidance of adverse impacts to fish and wildlife. In those instances where impacts cannot be avoided, the Service offer: recommendations for mitigating those impacts.

U.S. Geological Survey.-The North Slope continues to be the focus of most Geolngical Survey studies related to onshore oil and grs resources. These and other studies are briefly highlighted below.

* The operational phase of the Federal petroleum exploration program in the NPF.A was completed in 1981. More than 30 technical reports by Survey scientists are in the final stages of preparation for publication as a Geological Survey Professional Faper. Topics to be included are stratigraphy, sedimentation, seismic stratigraphy, petrography, paleontology, biostratigraphy, petroleum source-rock geochemistry, structural geology, direct hydrocaroon detection by aeromagnetic and helium methods, assessment results, and exploration history. A profuse'y illustrated non-technical report on this program was published in May 1985. Most dita from the 1974-81 exploration program, as well as numerous pertinent contractor reports, are available to the public through the National Geophysical and Solar-Terrertrial Data Center, Boulder, CO 80303. Their catalog itemizes information about 38 wells, 14,770 line miles of reflection seismic surveys, 52,000 gravity measurements, $\varepsilon$ nd numerous reports about geology, geophysics, the environment, construction, and lc cistics.

* Agreement was reached between th? Department of the Interior and the North Slope Borough on the transfer of the Barrow gas fields to the Borough. The Geological Survey had operated the gas fields and supplied the residents of Barrow since 1976. In 1984, the legislation was enacted and the transfer completed. The complex legislation granted the Borough subsurface rights to the South and East Barrow gas fields and the Walakpa gas ciscovery site, 
as well as $\$ 30$ million to defray costs of operating the field. The Arctic Slope Regional Corporation gave up subsurface rights to about 63,000 acres west of the NPRA and 102,000 acres south of the NPRA in the Gates of the Arctic National Park.

* Framework geologic studies continue for the area east of the NPRA: the Central Arctic Management Area and the Arctic National Wildlife Refuge. Reports issued for these areas in 1984 include information about oil and gas resource assessments (Bird, 1984), structural geology in the central Brooks Range (Kelley, 1984a, b), measured sections of Cretaceous and Tertiary rocks (Molenaar and others, 1984) and late Paleozoic and Mesozoic rocks (Detterman, 1984), low-altitude aeromagnetic surveys for petroleum (Donovan and others, 1984), and a newly compiled geologic map of the northern part of the Arctic NWR (Bader, 1984).

* A study of natural gas hydrates on the North Slope was initiated in 1984. The 3-year study, funded by the Department of Energy, has as its primary goal a detailed examination of data from northern Alaska about known gas hydrate occurrences and the synthesis of a model for their formation and occurrences. Ultimately, the work will lead to a gashydrate resource assessment.

* A team of scientists from the Geological Survey conducted field studies in the Aretic NWR in 1984 as part of a program to integrate surface geologic studies with subsurface seismic and well data to produce an oil and gas resource assessment of the ANILCA 1002 area, most of which is located on the coastal plain of the refuge. The assessment, scheduled for completion in 1985, will be part of an interagency (Bureau of Land Management, Fish and Wildlife Service, and U.S. Geological Survey) report to Congress in 1986. (For more details on the ANILCA 1002 study, see sections of this publication by the Fish and Wildlife Service and Bureau of Land Management.)

* A program to assess the quantities and distribution of undiscovered oil and gas resources beneath onshore Federal lands throughout the United States was initiated in 1984. A play-analysis technique will be used to systematically evaluate these lands. Many of the Survey's geologists who work in Alaska will be involved in this program because of the large amount of Federal land in Alaska. Anticipated products of this program include publications reporting the oil and gas resource estimates, methods of assessment, and petroleum geology and supporting data for areas assessed. Completion of this program is scheduled for late 1986 .
* Also initiated in 1984 was a nationwide program to study the evolution of sedimentary basins. The North Slope is one of six United States basins selected for study. The program, scheduled to last 5 years, is designed to provide a coordinated and multidi ciplinary approach to research studies in sedimentary basins of various types. The studies will investigate all aspects of the basin-its organic and inorganic component: fluids, physical and chemical conditions, ant changes and interactions through time-in addition to oil and gas resources. Anticipated products include new maps, charts, analyses, and other data reported with state-of-the-art interpretations.

* Geological Survey scientists continued their project to summarize the geology and evaluate the petroleum potential of all interior Alaska basins (those south of the North Slope and generally north of Cook Inlet as shown on fig. 3) during 1984. A 1-month helicoptersupported field program measured gr`vity and magnetic properties and studied strstigraphy in the Nenana basin and the Yukon Flats basin-Kandik fold beit. Geologic literature and geophysical and well data pertaining to these interior basins are summerized in Di Bona and Kirschner (1984). Several talks were presented on this project in $19^{\circ} 4$, and a map showing the basins was prefared for publication in the Decade of North American Geology volume on Alaska.

\section{INDUSTRY ACTIVITY}

Industry exploration and production antivity in Alaska during 1984 was directed to both on ?hore and offshore areas. Summaries of these activities have been published in Petroleum Information's Alaska Report for January 9, 1985. and the Oil and Gas Journal issue for June 25, 1984. A surnmary of North Slope petroleum development was also published in 1984 (Alaska Mines and Geology, October 1984). Only the highlights of onshore activities are summarized below.

* The compilation of information about industry surface geologic investigations is generally obtained from private scouting services, and statistics are normally released late in the year following the activity. Thus, information for 1984 will not be available until late 1985 . However, information for 1983 has also not been reported, and thus is not yet available. (See Jones and Hiles, 1984.)

* Data from 1984 industry geophysical su'veys are also obtained from private scouting services and will not be available until lete 1985 . During 1984, however, information about 1983 activity was published (Jones ard Hiles, 1984). In 1983, onshore geophysical surveys 
consisted of about 34 field-crew months, a 60 percent decrease over 1982. Most of these surveys were conducted on the North Slope.

* Four companies and one Alaskan Native corporation drilled 9 onshore exploratory wells in 1984 , as compared to 10 in 1983 and 13 in 1982. Seven of these wells are on the North Slope, one is in the Nenana basin, and one is in the Cook Inlet basin (table 2). Few data from these wells have been released. Several of the North Slope wells were drilled near known oil fields and have been suspended (as reported in several issues of Petroleum Information's Alaska Report). At year's end, two additional wells, one on the Alaska Peninsula and the other in the Cook Inlet basin, were nearing completion.

* Seven oil companies and several lease brokers representing numerous individual investors participated in one or more of the three competetive lease sales in 1984. They offered about $\$ 35$ million in high bids for about 650,000 acres of land (table 1). The Native village of Venetie received at least 20 of fers for leases to explore for oil and gas on tribal lands. These lands are located on the south flank of the Brooks Range about 140 miles east of the trans-Alaska pipeline (fig. 2). Little additional information on this sale has been made public (Anchorage Daily News, June 7, 1984).

* On the North Slope, Chevron USA, Inc., Sohio Alaska Petroleum Company, and BP Alaska Exploration Company completed a winter seismic survey in 1984 on 92,000 acres of Kaktovik village lands in the Arctic NWR (fig. 2). The companies have announced plans for an exploratory well to be drilled on these lands in early 1985.

* A winter seismic survey of the coastal plain of the Aretic NWR was completed by Geophysical Service, Inc., a subsidiary of Texas Instruments, for a 23-member group of oil companies. This survey, the first to be allowed in the refuge, is designed to provide more detailed information about the petroleum potential than was previously available from surface studies alone. Near the year's end, the Fish and Wildlife Service approved a second season of seismic work to provide more information about this area as recommended by scientists in the Bureau of Land Management and U.S. Geological Survey.

* The Prudhoe Bay field is ranked as the 19th largest oil field in the world (Tiratsoo, 1984) and is now about one-third depleted. To help sustain a daily oil production of about 1.5 million barrels (42 gallons per barrel), a seawater treatment plant was installed, and by year's end, about 1 million barrels per day of seawater was expected to be injected into the producing reservoir (Petroleum Information, Alaska Report, July 5, 1984). Emerging technology during the next 5 years will increase the recoverable roserves of the Prudhoe Bay field by 1.8 billion barrels, according Richard Bray, president of the Sohio Petroleum Company. Total recivery from the field would thus be increased to 11.4 billion barrels or slightly more than 50 percent of the original oil in place-a significantly better recovery than the normal oilficld recovery of 30 percent (Petroleum Information, Alaska Report, Oct. 10, 1984).

* Oil production from the Kuparuk River field at year's end was 182,000 barrels p?r day, making it the Nation's second largest producer. During 1984, installation of a second production facility and a new 24-inch pipeline that connects Kuparuk to the trans-Alaska pipeline resulted in nearly doubling daily production. These developments combired to push Kuparuk production past the Nations's previous No. 2 oil producer, Cilifornia's Elk Hills, which produced about 150,000 barrels per day (Oil and Gas Journal, July 30, 1984). During 1984, Kuparuk production averaged 126,400 barrels per day, approximately 16 percent more than in 1983. A landmark was reached August 23, 1984, when the field produced its 100 millionth barrel of oil. Approximately 110 production wells were drilled in this field in 1984, bringing the total number drilled to date to 240. Plans call for drilling an additional 140 wells in 1985. More than 725 wells will be needed to completely develop the field. Installation of a third production facility is scheduled for late 1986 , and continued drilling of production wells is expected to bring the field to its peak production rate of 250,000 bar'els per day in 1988. The current 60,000 barrel-per-day seawater injection program wi'l be expanded to serve the whole field in 1986. Major owners of the Kuparuk River field are ARCO Alaska, Inc., BP Alaska Exploration Company, Sohio Alaska Petroleum Comany, and Union Oil Company of California. Minor interest owners are Exxon Co. USA, Mobil Oil Corp., Phillips Petroleum Company, and Chevron USA, Inc. (Alaska Journal of Commerce ard Pacific Rim Reporter, Oct. 29, 1984).

* The Milne Point field is expected to begin oil production in early 1986 at an initial rate of 30,000 barrels per day. In 1984, Conoco, Inc., and its partners (Champlin Petroleum Company, Cities Service Oil and Gas Company, Chevron USA, Inc., ant Reading and Bates Petroleum Company) announced their decision to proceed with development. Initial production will come from the Kuparuk River reservoir. Development plans call for later 
production from Upper Cretaceous reservoirs, at a depth of 4,000 feet and containing 4-20degree gravity oil. Total recoverable oil from the field is expected to be 100 million barrels. Production will require an 11-mile, 14-inch pipeline to connect the field with the Trans-Alaska Pipeline System. Eighteen wells have already been drilled in the field, and first-phase development calls for the drilling of 24 more wells from two drilling pads (Oil and Gas Journal, March 5, 1984). A reservoir pressure maintenance program will operate concurrently with production by injecting 45,000 barrels of water per day (Anchorage Daily News, Feb. 24, 1984).

* ARCO Alaska, Inc. announced plans to begin development of the Lisburne oil pool, which underlies the northeastern part of the Prudhoe Bay field. ARCO estimates that this pool contains 1 to 3 billion barrels of oil in place. Ownership of the field is split among ARCO (40 percent), Exxon Company USA (40 percent), and Sohio Alaska Petroleum Company (20 percent). Combined development costs are estimated to be $\$ 1.5-2.0$ billion. Initial production, in 1987 , is scheduled to be 100,000 barrels of oil per day. The first phase of development will include drilling 180 wells, constructing six new drilling sites, and installing oil and gas handling facilities (Anchorage Times, Jan. 31, 1984). During 1984, ARCO received the necessary permits for onshore development and let contracts for production facilities (Oil and Gas Journal, Sept. 10, 1984).

* The Endicott oil field, located a few miles east of Prudhoe Bay and mostly offshore, is now scheduled for development. The decision, made in 1984, was announced by Sohio Alaska Petroleum Company. The U.S. Army Corps of Engineers has approved a 3-mile causeway connecting two gravel islands from which the field will be drilled and produced (Anchorage Daily News, Dec. 6, 1984). The development schedule calls for oil production to begin in 1988 at a rate of about 100,000 barrels per day. Ultimate recovery of about 350 million barrels is expected. Other interest owners are Amoco Production Co., ARCO Alaska, Inc., Exxon Corp., Union Oil Company of California, Doyon Ltd., Cook Inlet Region, Inc., and Northwest Alaska Native Association Regional Corp., Ine. (Oil and Gas Journal, Oct. 8, 1984).

* ARCO Alaska, Inc., announced the startup of a pilot project in 1984 to determine the feasibility of developing the multibillion barrel oil accumulation, West Sak. This accumulation overlies the Kuparuk oil field at depths of 3,000-4,000 feet (fig. 3). The field operators will inject hot water into the reservoir to heat the oil sufficiently to reduce its viscosity and make it easier to prcduce. In 1984,13 producing and injecting wells were in operation, producing 1,000 barrels of oil per day. Plans call for drilling additional wells. Other interest owners in this fielt are BP Alaska Exploration, Inc., Sohio Petroleum Company, Exxon Corp., and Union Oil Company of California (Alaska Journal of Commerce and Pacific Rim Reporter, Nov. 12, 1984).

* The Point Thomson field may contain 5 trillion cubic feet of recoverable gas, $35 \mathrm{n}$ million barrels of condensate, and minor amounts of oil, according to Exxon Company USA. This is the first public information about th? size and composition of this field since its discovery by Exxon in 1977. Commercial production of the field reportedly depends on the construction of a gas pipeline from the North Slope (Oil and Gas Journal, March 12, 1984).

* Chevron USA, Inc., planned to install $\varepsilon$ new enhanced oil recovery system in 1984 to recover an additional 3 million barrels of oil from the Swanson River field in the Cook Inlet basin. This was the first commercial oil field in Alaska, and it has already produced about 200 million barrels of oil in its 26-year life. So far, 46 percent of the original oil in place has been recovered. The company plans to increase the pressure of natural gas injected into the reservoir in order to make the gas combine more readily with the oil and push it from injection to producing wells. The field, once producing at 36,000 barrels per day (bpd) in 1967 , now produces at about 8,000 bpd (Anchorage Daily News, Jan. 25, 1984).

* During 1984, plans were made public for future oil and gas developments. Union Oil Company of California announced that gas production from the Cannery Loop field in the Cook Inlet basin is likely to begin within 3 years (Alaska Journal of Commerce and Pacific Rim Reporter, April 16, 1984). Renewed drilling at Katalla, the first oil field discovered in Alaska and located near the shore of the Gulf of Alaska, is planned for early 1985 by Alaska Crude Oil Corp.

\section{REFERENCES CITED}

Alaska Oil and Gas Conservation Commis rion, 1985, 1984 Statistical Report: Anchorage, 187 p.

Alaska Journal of Commerce and Pacific Rim Reporter, Pouch 4-9007, Anchorage, AK 99510.

Alaska Mines and Geology, published quarterly by the State of Alaska Department of Natural Resources, P.O. Box 80007, College, AK 99708.

Anchorage Daily News, 200 Potter Dr., Anchorage, AK 99503.

Anchorage Times, 540 West 4th Ave., Anchorage, AK 99501. 
Bader, J. W., 1984, Geologic map of the Demarcation Point, Mt. Michelson, Flaxman Island, and Barter Island quadrangles, Alaska: U.S. Geological Survey Open-File Report 84-596, 1 sheet, scale $1: 250,000$.

Bird, K. J., 1984, A comparison of the play-analysis techniques as applied in hydrocarbon resource assessments of the National Petroleum Reserve in Alaska and of the Aretic National Wildlife Refuge: U.S. Geological Survey Open-File Report 84-78, 21 p.

Detterman, R. L., 1984a, Measured sections of late Paleozoic and Mesozoic rocks, Mount Michelson quadrangle, Alaska: U.S. Geological Survey Open-File Report 84-331, 2 sheets.

Detterman, R. L., 1984b, Measured sections of upper Paleozoic to early Tertiary rocks, Demarcation Point quadrangle, Alaska: U.S. Geological Survey Open-File Report 84-370, 1 sheet.

Di Bona, P. A., and Kirschner, C. E., 1984, Geologic bibliography for selected onshore sedimentary basins of central and southern Alaska, addressing basin analysis and including an index of publicly available well and subsurface data: U.S. Geological Survey Open-File Report 84$99,70 \mathrm{p}$.

Donovan, T. J., Hendricks, J. D., Roberts, A. A., and Eliason, P. T., 1984, Low-altitude aeromagnetic reconnaissance for petroleum in the Aretic National Wildlife Refuge, Alaska: Geophysies, v. 49, no. 8., p. 1338-1353.

Jones, B. C., and Hiles, R. M., 1984, Oil and gas developments in Alaska in 1983: American Association of Petroleum Geologists Bulletin, v. 68 , no. 10 , p. $1266-1272$.

Kelley, J. S., 1984a, Geologic sections of a portion of the Chandler Lake B-1 quadrangle, Alaska: U.S. Geological Survey Open-File Report 84-77, 3 oversize sheets.

Kelley, J. S., 1984b, Geologic map and sections of a portion of the Chandler Lake A-1 and A-2 quadrangles, Alaska: U.S. Geological Survey Open-File Report $84-555,1$ sheet, scale $1: 63,360$.

Molenaar, C. M., Kirk, A. R., Magoon, L. B., and Huffman, A. C., 1984, Twenty-two measured sections of Cretaceous-Lower Tertiary rocks, eastern North Slope, Alaska: U.S. Geological Survey Open-File Report 84-695, 19 p., 4 sheets.

Oil and Gas Journal, published weekly by Pennwell Publishing Co., 1421 South Sheridan Road, Box 1260, Tulsa, OK 74101.

Petroleum Information, Alaska Report, published weekly by Petroleum Information Corp., a subsidiary of A.C. Nielsen, P.O. Box 102278, Anchorage, AK 99510.

Tiratsoo, E. N., 1984, Oilfields of the world (3rd ed.): Beaconsfield, England, Scientific Press, Ltd., 392 p.

\section{URANIUM RESOURCE:S}

A slump in demand for uranium has created a national surplus that has resulted in low prices and little exploration activity. Uranium deposits with very low production costs, such as high-grade surficial deposits, are the only currently economical operations, and none are in Alaska. The potentially high cost of development rules out production from known Alaskan uranium deposits and discourages further exploration.

\section{ACTIVITY BY FEDERAL AGENCIES}

U.S. Geological Survey.-A uranium occurrence in Death Valley on the Seward Peninsula (fig. 4) is being studied. The occurrence, which may have commercial potential, was discoveret in 1978 by Research Associates through the use of airborne radiometric devices. It was developec by Greatland Exploration, Ltd., and Houston International Minerals Co. from 1979 through 1981. Additional fieldwork and laboratory investigations started by the Geological Survey in 1982 are continuing. This deposit was briefly described by Dickinson and Cunningham (1984; this and other references cited are listed at the end of this section). The host sandstone contains abundant carbonac?ous material and is interbedded with other lithologies deposited in a fault-bounded depression that is an extension of the Death Valley basin. Fieldwork in the area is planned for 1985, and laboratory invertigations are under way.

Field studies and laboratory wcrk in several other areas, including Admiralty Islard (Pybus Bay area; fig. 4) and the Healy Creek coal basin (fig. 4), are in progress.

A guide to a folio of geologic information about the Medfra quadrangle defir os favorable areas for beryllium-fluorite-uranium vein deposits in the area (Patton and others, 1984). An additional geologic report about previously completed studies of uranium geology in the southern part of the Admiralty Trough, southeastern Alaska, has been published (Dickinson and Campbell, 1.984). Gough and others (1984) released results of a chemical survey, including uranium and thorium, of soils and other surficial materials in Alaska.

Department of Energy.-The Department of Energy issued a report about a study that involved collection and analysis of samples of stream sediments, groundwater, and surface water from the conterminous States and Alaska to determine concentrations of uranium and other selected elements (Bendix Field Engineering Corp., 1984). The Department's National Uranium Resource Evaluation program has been terminated, and during 1984 nonproprietary information was transferred to the Geological Survey offices in Denver. Further information about this material is given in the introductory pages to this circular. 


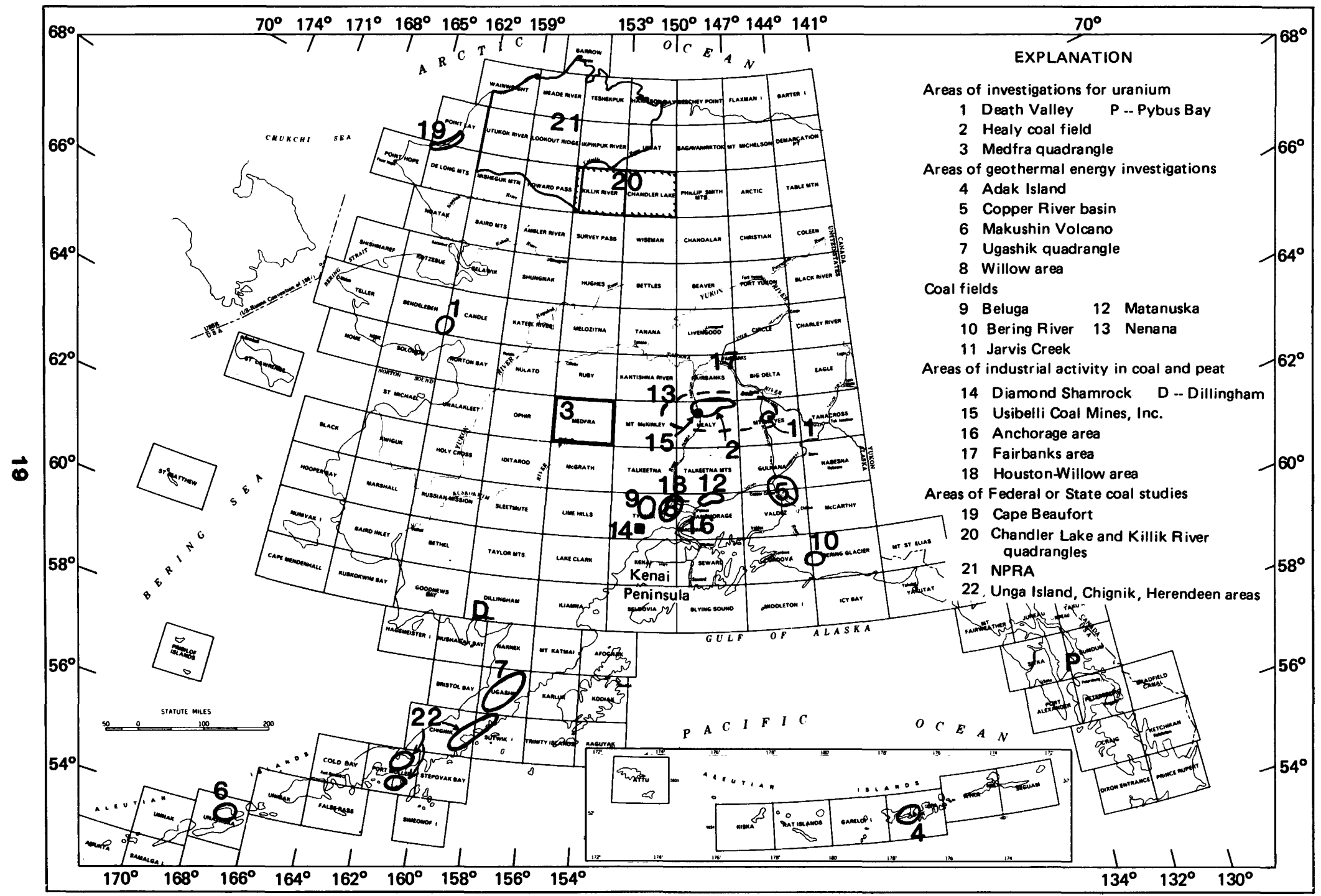

Figure 4.-Areas of Federal, State, and industry activity for uranium, geothermal, coal, and peat resources. 


\section{REFERENCES CITED}

Bendix Field Engineering Corp., 1984, Guide to data reports of the hydrogeochemical and stream sediment reconnaissance: Washington, D. C., Department of Energy, GJBX-5(84), 228 p.

Dickinson, K. A., and Campbell, J. A., 1984, Uranium geology of the Kootznahoo Formation of the southern part of the Admiralty Trough, southeastern Alaska: Journal of the Alaska Geological Society, v. 4, p. 1-11.

Dickinson, K. A., and Cunningham, Kenneth, 1984, Death Valley, Alaska, uranium deposit: Geological Society of America Abstracts with Programs, v. 16, no. 5, p. 278.

Gough, L. P., Peard, J. S., Severson, R. C., Shacklette, H. T., Tompkins, M. S., Stewart, K. C., and Briggs, P. G., 1984, Chemical analyses of soils and other surfical materials: U.S. Geological Survey Open-File Report 84-423, $77 \mathrm{p}$.

Patton, W. W., Jr., Moll, E. J., and King, H. D., 1984, The Alaskan Mineral Resource Assessment Program-Guide to information contained in the folio of geologic and mineral-resource maps of the Medfra quadrangle: U.S. Geological Survey Circular 928, 11 p.

\section{GEOTHERMAL RESOURCES}

Alaska's geothermal resources are used only locally and on a small scale for recreational purposes, space heating, and agriculture. However, the widespread centers of volcanism and of fumarolic or hydrothermal activity in the State suggest a large geothermal energy potential. Development of this potential is likely where markets currently or potentially occur-for example, ports in the Aleutian Islands or along transportation corridors near the Wrangell Mountains.

\section{ACTIVITY BY FEDERAL AGENCIES}

U.S. Geological Survey.-A cooperative effort between the Department of Geology at Rice University and the Geological Survey was begun in 1984 as part of a field and chemical study of the volcanic history and geothermal potential of Kialagvik, Chiginagak, and Yantarni volcanoes on the Alaska Peninsula. These studies are a continuation of the Survey's Geothermal Investigations program, which in Alaska emphasizes geologic mapping of volcanic centers to better recognize those that may have young, shallow magma chambers.

\section{STATE STUDIES}

In 1982 and 1983, under contract to the Alaska Power Authority (APA), Republic Geothermal, Inc., carried out surface studies and drilling to confirm a geothermal reservoir on the flanks of Makushin Volcano (fig. 4). Steam at $379^{\circ} \mathrm{F}\left(193^{\circ} \mathrm{C}\right)$ was confirmed at a depth of 1,949 feet in 1983 . Continuing in 1984, Republic performed a flow test over a 34-day period, during which tho bottom-hole temperature was maintained at $1 \subseteq 3^{\circ} \mathrm{C}$. "The Unalaska geothermal exploration prcject, Phase II final report," prepared by Republic for the APA, was made available in June 1984. The report covers all field activities and presents data obtained by the close of the 1983 season. "The Unalas'a geothermal exploration project, Executive final report," which includes the results of the 1984 season, was released in December 1984. (Citations for thase and other reports mentioned are listed at the end of this section.) Other topical papers about a variety of geologic, hydrologic, chemical, and geophysical features of the Makushin Volcano area have been published in the Transactions of tha Geothermal Resources Council (its volume 7, published in 1983) and by the Alaska Division of Geological and Geophysical Surveys (ADGGS) (Nye, Queen, and Motyka, 1984; Motyka, Moorman, and Poreda, 1983).

The State's Geophysical Institute in 1984 evaluated data collected previously on the geothermal potential of the Willow area in southcentral Alaska and on several aroas of mud volcanoes in the Copper River basin (fig. 4). Some studies in the Copper River basin vere made in conjunction with ADGGS. Reports about the Copper River basin have been released (for example, Westcott and Turner, 1983). A statewide geothermal resources map was publish sd by ADGGS in 1984 (ADGGS, 1984), following an earlier report of a reconnaissance study of hydrothermal resources in the Aleutian Arc (Motyka, 1983).

The Energy Program Management Office, Naval Weapons Center, China Lake, Calif., called a meeting of interested agencies and other parties in Anchorge in 1984 to discuss potentikl geothermal development on Adak Island (fig. 4). A summary of results obtained during previous gechhysical and geologic surveys on the island was presented, and a concerted effort to secure funding for deep drilling to confirm a geothermal resource on Adak Island was announced.

\section{REFERENCES CITED}

Alaska Division of Geological and Geophysical Surveys, comp., 1984, Geothermal resources of Alaska: Produced by the Nationa] Oceanic and Atmospheric Administration for the Department of Energy, 1 sheet, scale 1:2,500,000.

Motyka, R. J., 1983, High-temperature hydrothermal resources in the Aleutian Arc: Journal of the Alaska Geological Society, v. 3, p. 87-99.

Motyka, R. J., Moorman, M. A., and Poreda, Robert, 1983, Progress report-Thermal fluid investigations of the Makushin geothermal area: Alaska Division of Geological and Geophysical Surveys Report of Investigations 83-15, 52 p., $1 \mathrm{pl}$. 
Nye, C. J., Queen, L. D., and Motyka, R. J., 1984, Geologic map of the Makushin geothermal area, Unalaska Island, Alaska: Alaska Division of Geological and Geophysical Surveys Report of Investigations $84-3,1$ sheet.

Republic Geothermal, Inc., 1984, The Unalaska geothermal exploration project, Phase II final report: Alaska Power Authority, sections individually paginated.

Repubic Geothermal, Inc., 1984, The Unalaska geothermal exploration project, Executive summary report: Alaska Power Authority, $33 \mathrm{p}$.

Westcott, E. M., and Turner, D. L., 1983, Geothermal energy resource exploration of the eastern Copper River Basin, Alaska: Geothermal Resources Council, Transactions, v. 7, p. 211-213.

\section{COAL AND PEAT}

A landmark in Alaska's infant coal export industry was reached when coal left Healy (Nenana coal field) in December 1984 by the Alaska Railroad, bound for Seward to be shipped to Seoul, Korea. This event capped many months of planning, negotiation, and construction, some of which was described in the 1984 circular of this series.

of the 10 medium to large coal fields in Alaska, four were of particular interest to industry in 1984: the Beluga field, the Nenana field, the Bering River field, and the Matanuska field (fig. 4). The State continues to study coal in the northwestern part of Alaska and in the Matanuska, Herendeen Bay, Chignik, and Unga Island coal fields (fig. 4).

\section{ACTIVITY BY FEDERAL AGENCIES}

U.S. Geological Survey.-The Geological Survey has been investigating the southeastern part of the Northern Alaska coal field as part of its Alaska Mineral Resource Assessment Program (AMRAP) work. (See the nonfuel minerals section for a description of AMRAP.) The northern parts of the Killik River and Chandler Lake quadrangles (fig. 4) contain coal that has a low sulfur content $(0.13-$ 0.43 percent) and an apparent rank of high volatile $B$ bituminous. Preliminary results of Geological Survey studies indicate that the coal also has low concentrations of elements of environmental concern and elements that have economic potential as by-products of coal utilization.

The Geological Survey has also been examining coal and associated rocks in the eastern half of the National Petroleum Reserve in Alaska (fig. 4). Preliminary results of these studies suggest that the coal formed in deltaic environments. It has a low sulfur content and an apparent rank of high volatile $\mathrm{C}$ bituminous.

The Cook Inlet coal lands are of continuing interest to the Survey, which has been studying the engineering aspects of geologic materials in these coal fields. Drilling has been an important part of these studies. In 1984 the Geological Surv?y drilled a hole in the western part of Anchorige that penetrated 250 feet of possible Tyonek Formation (the unit in which most Cook Inlet coal is found). The hole was drilled as part of ongoin? seismic hazard evaluation studies and stratigraphic investigations in the area.

Bureau of Land Management.-The Bureau of Land Management continued its work on two preference right lease applications. Interest in coal leasing on Federal lands in Alaska is currently low.

\section{STATE ACTIVITY}

The City of Seward sold $\$ 12$ millicn in taxexempt industrial bonds to finance constru?tion of a coal-loading facility in the port of Seward. The construction was completed in late 1984, and the installation consists of a conveyor system and a stacker-reclaimer capable of handling 1,070 metric tons per hour. The facility was built to handle shipments of coal from the Usibelli mine to Korea.

After a series of public hearings, the Department of Natural Resources of fered nine tracts in a coal lease sale in December 1984. The tracts encompassed 13,865 acres in the Wishbon? Hill and Moose Creek areas of the Matanuska coal field (fig. 4). According to the Anchorage Daily News (June $14,1984)$, this area contains at least 100 million tons and possibly as much as 500 millicn tons of coal. The State will receive more than $\$ 15,000$ annually in rent until coal is produced or the leases lapse (Petroleum Information, Alaska Report, Dec. $19,1984)$. (See industry activities, below.)

The Division of Geological and Goophysical Surveys began an investigation of coal fields in the Herendeen, Chignik, and Unga Island areas (fig. 4). The study is synthesizing all available data, setting up a sampling program to determine coal quality, and studying the geologic history of the areas.

The Alaska Legislature has ap?ropriated $\$ 2$ million for the Alaska Native Fourdation to develop a preproduction program for coal in the Cape Beaufort area (fig. 4) (Alaska dournal of Commerce and Pacific Rim Reporter, Nov. 12, 1984). This area is part of one of the world's largest coal provinces, which contains potential cokingquality coal resources. The program will identify locations of future mines, transportatior methods, marketing strategy and coal uses, and environmental issues. A recent study of the area indicated that as much as 90 percent of the diesel fuel currently used in this part of Alaska could be replaced by coal.

\section{INDUSTRY ACTIVITY}

The following paragraphs present hixhlights of the 1984 activities by private industry. 
* The Diamond Shamrock Coal Company was trying to secure markets for its 1 billion tons of lowsulfur subbituminous coal in the Beluga coal field (fig. 4) (Anchorage Daily News, May 10, 1984). The coal field is 12 miles from tidewater. The company has estimated that it will cost $\$ 600$ million to develop a mine, construct a conveyor to tidewater, and build a coal-loading facility. Early in 1984, Diamond Shamrock took 210 tons of the Beluga coal to Japan (Alaska Journal of Commerce and Pacific Rim Reporter, March 5, 1984). Mitsuibishi Heavy Industries, Ltd., Japan, began combustion tests. Potential users, such as utility companies and cement and paper mills, were invited to observe the testing.

* Diamond Alaska Coal Company, a subsidiary of Diamond Shamrock, reached an agreement with the Japanese Electric Power Development Company to study development of coal in the Beluga coal field. The Environmental Protection Agency was preparing an environmental impact statement (EIS) for the project. The project calls for open-pit mining and reclamation of about 5,000 acres, of which 450 acres would be worked at any time. Average pit depth would be 200 feet. Crushed coal would be taken by conveyor to loading facilities. The EIS will cover most aspects of the project, including mine wastewater (Alaska Economic Report, Jan. 14, 1985; Alaska Journal of Commerce and Pacific Rim Reporter, March 4, 1985).

* Rocky Mountain Energy, Inc., with Rock Springs Royalty Company, was the high bidder on three tracts totalling 5,224 acres in the State's coal lease in the Matanuska coal field (fig. 4) (Alaska Journal of Commerce and Pacific Rim Reporter, Dec. 17, 1984). Rocky Mountain Energy and Hawley Resource Properties, Inc., have tentative plans for a minemouth powerplant, a \$410-million complex capable of generating 150 megawatts for distribution to a power network in southcentral Alaska. Action on this plan depends on the principals' receiving a commitment to purchase the power. Expected run-of-mine production would be about 700,000 tons of coal annually. Coal will be trucked from the mine to an underground hopper. Environmental concerns are being addressed in plans for power generation and reclamation (Alaska Journal of Commerce and Pacific Rim Reporter, Jan. 28, 1985).

* The Matanuska Electric Association, the only other bidder in the Matanuska coal lease sale, offered the minimum amount stipulated by the State. The utility company is seeking alternative power sources for the next decade and beyond. By bidding on the tracts, it can hold them for 10 years; otherwise, the unsought land would return to State control and possible future lease offerings.

* KADCD, the Korea-Alaska Development Company, completed a fourth season of geologic mapping and exploratory drilling in the Bering River coal field (fig. 4). The company is a joint venture among Samsung C -mpany, Ltd., Daesung Company, Samchok Company, and Hyundai Corp. of Korea and the Chugach Alaska Corporation, a Native organization. According to the Alaska Ecoromic Report (Sept. 6, 1984), the 72,000 acr?s of Nativeheld land in the coal field is less than 60 miles from Cordova and contains anthracitic coal of higher quality than most coal in the State. This field has as much as 160 million to 1 billion tons of coal (Alaska Journal of Commerce and Pacific Rim Reporter, July 30, 1984). The company's plans call for from 40 to 50 percent of the coal to $b$ exported to Korea by way of a port to be bi ilt at Katalla and a mine-mouth powerplant th't would burn a mix of coal dust and oil ard that could supply electricity to the city of Cordova as early as 1989. A spokesman for the company reported (Alaska Journal of Commerce and Pacific Rim Reporter, Feb. 18, 1985) that the area to be mined first has been selected and that the studied area contairs nearly 59 million tons of mineable coal, $\mathrm{u}$ ith a reserve of about 35 million tons. The company supports construction of a road to Cordova and spurs to both the coal area and the Katalla oil field. Economic studies are continuing.

* The Usibelli coal mine in Healy (Nenana coal field, fig. 4) shipped its first 10 railroad cars ( 800 metric tons) of coal to Suneel Alaska Corporation's facility in Seward in December. 1984. Other shipments of about 5,000 metric tons were ready to ship at the end of the year. Anchorage newspapers reported that the mine plans to ship 15,000 metric tons a week in three shipments, for a total of 800,000 metric tons a year. Regular 60-car trains loaded with coal are experted to travel the rail route to Seward in 1985 .

* The Suneel Alaska Corporation began loading the Usibelli coal at its Seward facilit ' in late 1984 (Anchorage Times, Dec. 21, 1984). The loading of the first Suneel ship, tre 65,000-ton bulk carrier $M / V$ Northern Light, was expected to take about a week. The coal will be sold to the Korean Electric Power Association.

* Negotiations were in progress with th? Jarvis Coal Company of Fairbanks for supplying the Fort Greely power plant with coal from the Jarvis coal field. A report by the Alaska Division of Geological and Geophysical Surveys (Eakins and others, 1985) noted that startup is projected for 1986 or 1987. Other power 
companies in interior Alaska were also reported to be considering switching from currently used oil to coal.

\section{ACTIVITY IN PEAT}

According to the Alaska Journal of Commerce and Pacific Rim Reporter (Nov. 12, 1984), there may be as many as 4.4 million acres of fuel-grade peat in Alaska. An estimated 0.88 billion tons of moisture free, fuel-grade peat occurs in beds more than 5 feet thick. The article noted that in 1984 peat assessment studies were focused at Rogers Creek, Houston, and the Kenai Peninsula, as well as at Dillingham (fig. 4), where the Bristol Bay Native Association is active in this work. Peat is being mined from two pits near Willow and four pits near Fairbanks, as well as pits in the Anchorage area. The Alaska Division of Geological and Geophysical Surveys (Eakins and others, 1985) reported that approximately 125,000 cubic yards of peat were mined in 1984 statewide; this amount is a large apparent increase relative to 1983 , but peat production has probably been under-reported in the past. Peat is used primarily in agriculture and greenhouses, with minor use for heating in some villages.

\section{REFERENCES CITED}

Alaska Economic Report, published by the Alaska Information Service, 3037 South Circle, Anchorage, AK 99507.

Alaska Journal of Commerce and Pacific Rim Reporter, 715 L Street, Anchorage, AK 99501.

Anchorage Daily News, 200 Potter Drive, Anchorage, AK 99502.

Anchorage Times, 840 West 4 th Avenue, Anchorage, AK 99501.

Eakins, G. R., Bundtzen, T. K., Lueck, L. L., Green, C. B., Gallagher, J. A., and Coleman, D. A., 1985, Alaska's mineral industry, 1984: Alaska Division of Geological and Geophysical Surveys Special Report 38, 57 p.

\section{NONFUEL MINERALS}

Alaskan nonfuel-mineral exploration, development, and mining was severely impacted in 1984 by the malaise, if not depression, in metal mining. Most metal prices are lower than they have been in decades, and while an eventual recovery in metal prices and the American mining industry is probable, it is unlikely that the impact of foreign competition will lessen in the near future. At the end of 1984, the situation was so severe that one national business journal, Business Week (Dec. 17, 1984), had "The Death of Mining" as its featured article; the article concluded that U.S. mining was in dire straits and few signs pointed to a major recovery in the near future.

However, the Alaskan mining and exploration scene is probably not so bleak as the general state of the national mining industry would indicate. Metals will certainly continue to be required by our and the world economy, probably in increasing amounts if the national economy continues to improve. Several deposits now being deroloped in Alaska are very large and (or) high grade. They may well be able to compete on a world scale 1 reasons of their size and grade, through imaginative strategies to establish a significant share of the market, or with economies of scale or operation. In addition, while precious metal prices are not buoyant and, in fact, dropped during much of 1984 , the prices of gold and silver are still high enough to encourage major Alaskan precious metal exploration, development, and mining. Alaska's historically large gold production over mone than $\mathbf{8 0}$ years sustains a degree of optimism for gold mining, as does the probability that many of Alaska's lode mineral deposits have yet to be found. If large, high-grade mineral deposits that can comfete in the world economy remain undiscovered in the United States, they are very likely to be in Alask .

To at least some, the long-term prognosis for development of Alaska's mineral resources is very favorable. At an April 1984 meeting of the Alaska Export Conference in Fairbanks, an of ficial of the Department of Commerce predicted an eventual "tremendous minerals boom in Alaska" as the highgrade deposits of the conterminous S'ates are depleted and the Third World begins to develop. Several other speakers at the meeting stressed the vital importance of transporation to a viak's mining industry in Alaska (Alaska Journal of Commerce and Pacific Rim Reporter, April 9, 1984).

In a review article, Sims and Gre?n (1985, listed with all other cited articles at the $\epsilon$ nd of this section) presented a strong case that within 10 to 15 years several new mines producing coal, zinc and related base metals, gold and silver, ard molybdenum will come to eclipse construction minerals and placer gold as the dominant elemerts of the Alaskan minerals industry. The mining industry would then be second only to oil and gas in the State's economy and could have a gross value of more than $\$ 3$ billion per year.

According to preliminary figures furnished by the staff of the Alaska Division of Geolngical and Geophysical Surveys, (Alaska Division of Geological and Geophysical Surveys, written commun., 1985), the number of new mining claims staked continues to decline compared to the last several years. (See also Eakins and others, 1985.) About 8,400 claims were staked in 1984, as compared with 10,745 in $1983,14,958$ in 1982 , and 27,397 in 1981. Similarly, exploration expenditures continue to drop from a high of about $\$ 80$ million in 1979 to $\$ 35$ million in 1983 , to about $\$ 23$ million in 1984 .

However, mineral production (table 3 ) shows only a small decrease from 1983. As ir previous years, the major commodities that were produced were sand and gravel (\$95 million), gold (\$63 
Table 3.-Mineral production in Alaska, 1983-84 (from Eakins and others, 1985)

\begin{tabular}{lcccc}
\hline $\begin{array}{l}\text { Commodity } \\
\text { (reporting } \\
\text { unit) }\end{array}$ & $\begin{array}{c}1983 \\
\text { quant ity }\end{array}$ & $\begin{array}{c}1984 \\
\text { quantity }\end{array}$ & \multicolumn{2}{c}{$\begin{array}{c}\text { Value in millions } \\
\text { of dollars }\end{array}$} \\
\hline Gold (ounces) & 169,000 & 175,000 & 67.6 & 1984 \\
Ant imony (pounds) & 22,400 & 135,000 & .025 & .03 \\
Plat inum (ounces) & wi thheld & withheld & .10 & withr $: 1 d$ \\
Mercury (pounds) & not reported & 380 & not reported & .091 \\
Silver (ounces) & 33,200 & 20,000 & .33 & .16 \\
Tin (pounds) & 215,000 & 225,000 & 1.10 & .40 \\
Jade and soapstone (fons) & 2.3 & 5.5 & .042 & .016 \\
Sand and gravel (mmt $)$ & 50.0 & 27.0 & 105 & 95 \\
Building stone (mmt) & 5.3 & 2.7 & 20 & 16 \\
Coal (tons) & 803,000 & 849,161 & 18.0 & $23 . \varepsilon$ \\
Peat (cubic yards) & 15,000 & 125,0000 & .20 &.$\varepsilon$ s \\
\hline
\end{tabular}

1 Million metric tons

million), coal ( $\$ 23.8$ million), and building stone ( $\$ 16$ million), with lesser production of peat, antimony, silver, jade and soapstone, platinum, and mercury. The production of sand and gravel was about half that of 1983 , mainly because of decreased demand from petroleum operations on the North Slope. The amount of gold production was slightly larger than that of 1983, but the decline in the price received resulted in about a 7-percent drop in the value. A sharp increase in both demand for and the price of antimony during 1984 resulted in almost six times more production in 1984 than 1983, with an orderof-magnitude increase in value. Silver production was down sharply, but most was produced as a byproduct of placer gold mining and the figures have considerable uncertainty. Coal production continues to climb, and peat, used largely for agricultural purposes, showed a marked increase in reported production.

The amount spent for development of mineral properties in 1984 increased relative to 1983 , reflecting investments on projects at Quartz Hill, Red Dog, and Greens Creek (discussed under industry activities later in this section), as well as at the coal transportation facilities at Seward.

President Reagan signed the Arctic Research and Policy Act in 1984, culminating several decades of work by Alaskan scientists and legislators. The bill was created to coordinate Federal and State research efforts in the Arctic and to assist in the efficient and responsible development of Arctic mineral resources. The bill also recognizes the susceptibility of the arctic environment and is designed to work toward a balance between environmental protection and cost-effective development (Alaska Miner, October 1984, p. 32-38.)

One of the prominent topics at the Ninth Annual Alaska Miners Association Convention was the involvement of the Native corporations in Alaskan
Inineral development. Most of these corporations have participated in mineral exploration, primarily in oil and gas or coal exploration ard usually in partnership with private industry. For example, the Northwest Alaska Native Association (I'ANA) based in Kotzebue is a partner with Cominco Ltd. to develop the Red Dog deposit in northwestern Alaska. Several of the speakers from the Native corporations stressed that their participation in mineral exploration will continue in view of the Natives' strong land position in the Ste te and their need for income from this land and for jobs in their areas (Alaska Journal of Commerce and Pacific Rim Reporter, Oct. 22, 1984).

Land-use planning continues to be a major activity of numerous Federal and State agencies in Alaska. Few areas of Federal or State land in the State are not the subject of at least one, and commonly several, land management plans. Two of the plans announced in 1984 raised considerable controversy. One is the Bristol Bay stuly, begun in 1981 as a requirement of ANILCA. In 1984, the Federal government requested that the State consider more public comment on minerals (among other issues) before implementing its management plan for that region. The Federal government felt that numerous recent changes in the plan were of such magnitude as to require another piblic review (Anchorage Times, March 12, 1984). And in October, the Bureau of Land Management released its proposed management plan for the 2.2 million acres of the Steese National Conservation Area and the White Mountain National Recreational Area established by ANILCA north of Fairbanks. The initial reaction to several elements of the plan by miners and environmental groups was unfavorable. The miners objected in particular tc provisions relating to historical access to mining claims, water-quality standards, and the amount of land to 
be closed to mining. In early 1985 , protests were being reviewed in the office of the Director of the Bureau of Land Management.

As an indication of its commitment to enhancing mineral development, the Alaska Legislature approved funds to develop a curriculum to introduce fourth-, fifth- and sixth-grade students to the the Alaskan mining industry. The \$322,000 curriculum package is jointly funded by the Alaska Miners Association and the State of Alaska and is under the aegis of the Alaska Mineral and Energy Resource Education Fund organization composed of members of both government and industry; completion was planned for early 1985 . The curriculum will explain the importance of minerals in everyday life and provide Alaskan teachers with multimedia material, including "The Alaska Resources Kit: Minerals", for conveying this information to students (Anchorage Times, Oct. 31, 1984: Alaska Journal of Commerce and Pacific Rim Reporter, Oct. 29).

Nerco Minerals Company in Fairbanks has made a grant of $\$ 144,000$ to the University of Alaska to establish a hydrometallurgical research facility at the Mineral Industry Research Laboratory. The grant is for one year, with consideration for further yearly grants, to develop techniques to process complex Alaskan ores (Petroleum Information, Alaska Report, Jan. 23, 1985).

The theme of education was also prominent at the 1984 Alaska Miners Convention. Several speakers stressed the importance of educating the public about the importance of minerals to our economy and well-being (Anchorage Daily News, Nov. 4,1984 ).

The status of submerged lands under Alaska's navigable lakes and rivers continues to be a point of contention between the State and Federal governments; several environmental groups and Native corporations have also become involved in this issue. Some of these lands may have resources of oil and gas, coal, or metallic minerals. Under the Statehood Act of 1959 , title to such lands was to pass to the State; subsequently, several Native corporations have claimed some of this land under the 1971 Alaska Native Claims Settlement Act. A major point of concern is that the definition as navigable for a particular lake or river can be decided only in the U.S. District Court. Few navigability cases have been filed, although the statute of limitations imposes fast-approaching deadlines for such litigation. In February 1985 a U.S. District Court judge rejected a delay in the suit brought by several environmental groups challenging a Department of the Interior policy to convey certain submerged lands to the State of Alaska and Native corporations. Meanwhile, the Alaska Congressional delegation introduced bills to resolve the issue by legislation (Anchorage Times, Feb. 21, 1985; Anchorage Daily News, Feb. 22, 1985).

\section{ACTIVITY BY FEDERAL AGENCIES}

In addition to information about agency programs or accomplishments in the nex. pages, discussion of ageney activity is also included in descriptions of various industrial projects.

U.S. Geological Survey.-The Geological Survey continues its numerous studies throughout th ? State, many of which are related to nonfuel miner $1 \mathrm{~s}$. The Alaska Mineral Resource Assessment Program (AMRAP) activities were at approximately the same level as in the past several years. Studies of areas proposed as wilderness that were a prominent part of the Survey's Alaska work in recent y?ars are largely complete, at least for the present. The Survey's considerable work that began in 1975 on the National Petroleum Reserve in Alaska to delineate petroleum and nonfuel mineral resources is almost complete; only a few reports remain to be published. Locations of areas that were studied in 1984 by the U.S. Geological Survey and the Bureau of Mines' Mineral Land Assessment Program are depicted on figure 5 , and table 4 lists the projects that are included.

AMRAP functions at four levels of progressively greater detail to protuce a comprehensive picture of Alaska's geology and its mineral and energy endowment. Level $I$ is at the State level; its map products are usually at a scale of $1: 2,500,000$. In 1984, new summaries of Alaskan deposits of gold, silver, tungsten, and mol"bdenum (Cobb, 1984a-d) were published. Work continues on maintaining a mineral data base for the entire State. (See also the Mineral Investigations Resource Maps listed in the "Selected references" at the back of this circular.)

Level II is at the regional scale; resultant maps are usually at a scale of about 1:1,000,000. At Level II, Berg's (1984) major synthesis covers the geology, mineral deposits, and areas of mineral potential of southeastern Alaska. This is the final report in a series of Regional AMRAP efforts that was begun in 1978 .

Level III is presently the main thrust of the AMRAP prgram. The work consists of multidisciplinary team studies of selected quadrangles, with emphasis on the collection of new geologic, geochemical, and geophysical data in the field. The studies are designed to produce an inventory of areas of mineral resource potential in these quadrangles. In 1984, new $1: 250,000$-scale AMRAP studies were begun in the Craig and Dixon Entrance quadrangles of southeastern Alaska anc in the Gulkana quadrangle in south-central Alaska. AMRAP fieldwork continued in the Juneau and Taku River quadrangles in southeastern Alaska; in the Port Moller, Stepovak Bay, Mt. Katmai, and Naknek quadrangles on the Alaska Peninsula; and in the Baird Mountains, Killik River, and Chand'er Lake quadrangles in the Brooks Range. Fieldwork is complete in the Anchorage and Healy quadrangles in south-central Alaska; the Solomon and Bendeleben 


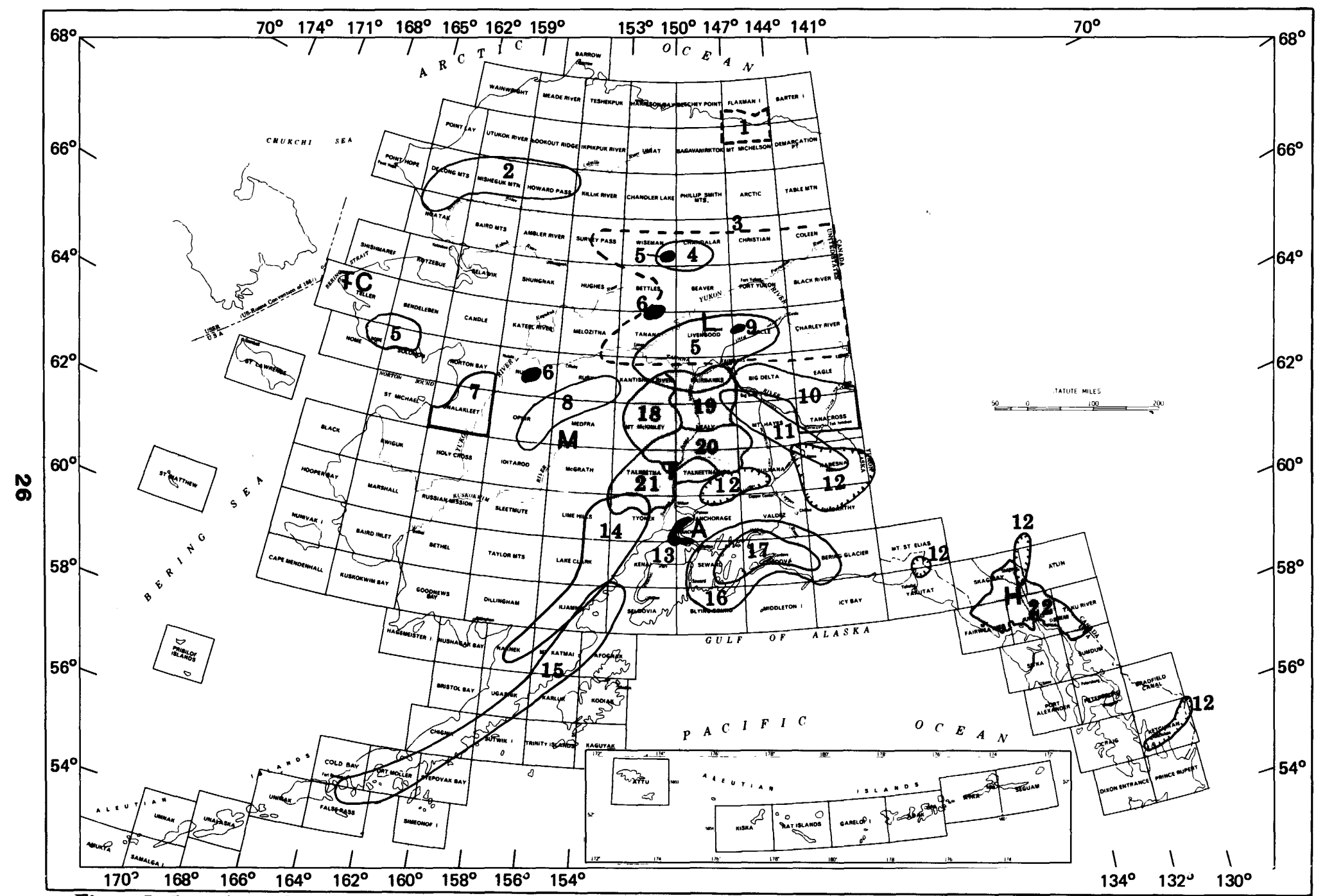

Figure 5.--Locations of areas studied by the U.S. Geological Survey and Bureau of Mines for nonfuel minerals; not shown are the locations of paleomagnetic studies and studies of gold placers, which take place in many parts of Alaska. See table 4 for titles or brief descriptions of projects. 
Table 4.-Abbreviated titles or brief descriptions of projects whose study areas are shown on figure 5

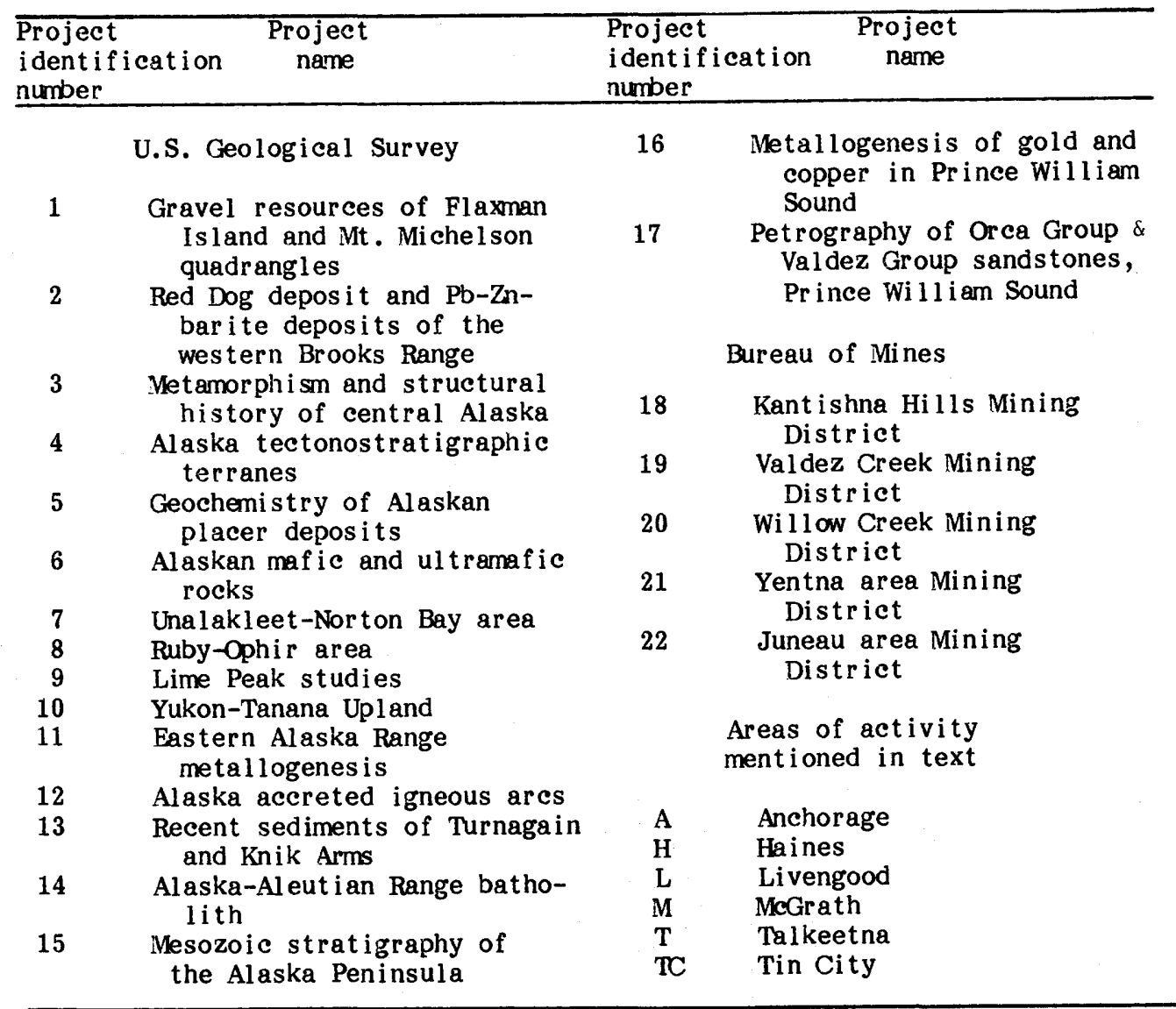

quadrangles on the Seward Peninsula; the $\mathrm{W}$ iseman quadrangle in the Brooks Range, and the Petersburg quadrangle in southeastern Alaska. Reports from these projects are now being prepared or just beginning to be published. A U.S. Geological Survey Circular (Patton and others, 1984) summarizes the results of the AMRAP effort in the Medfra quadrangle in central Alaska. Figure 6 shows the current status of AMRAP studies at Level III. In addition to the AMRAP mineral resource assessment studies, geologic mapping is being done at $1: 250,000$ scale in several areas, notably the Unalakleet and Norton Bay area and in the Ruby and Ophir quadrangles in western and west-central Alaska.

Level IV studies consist of detailed work, usually at $1: 63,360$ scale or larger, in mineral districts and at specific deposits; some are projects at various scales that relate to specific topics of Alaskan geology or mineral deposits. The locations of these Level IV studies are shown in figure 5, and the projects are listed on table 4. Among the Level IV studies begun in 1984 are: an examination of the stratiform lead-zinc-silver deposits of northwestern
Alaska, the geochemistry of Alaskan placer gold deposits, and a metallogenic study of the gold and copper deposits of the Prince William Sound area.

More than 50 publications resulted from Level III and IV efforts in 1984. Many of these are listed among the references at the back of this circular.

In 1984, a major new program was initiated to investigate the Earth's crust and upper mantle along a north-south corridor paralleling the route of the trans-Alaska pipeline and extending of fshore across the Pacific and Arctic continental margins. This is the Trans-Alaska Lithosphere Investigation (TALI). In May, a workshop was held in Anchorage to bring together the main participants in the program-the National Science Foundation, the U.S. Geological Survey, the University of Alaska, and the Alaska Division of Geological and Geophysical Surveys. The objectives of the workshop were to draft a program prospectus, define the problems to be investigated along the corridor, recommend strategy and types of investigations that should be pursued, and document relevant ongoing and scheduled investigations. A major component of TALI is the Trans-Alaska Crustal Transect (TACT) 


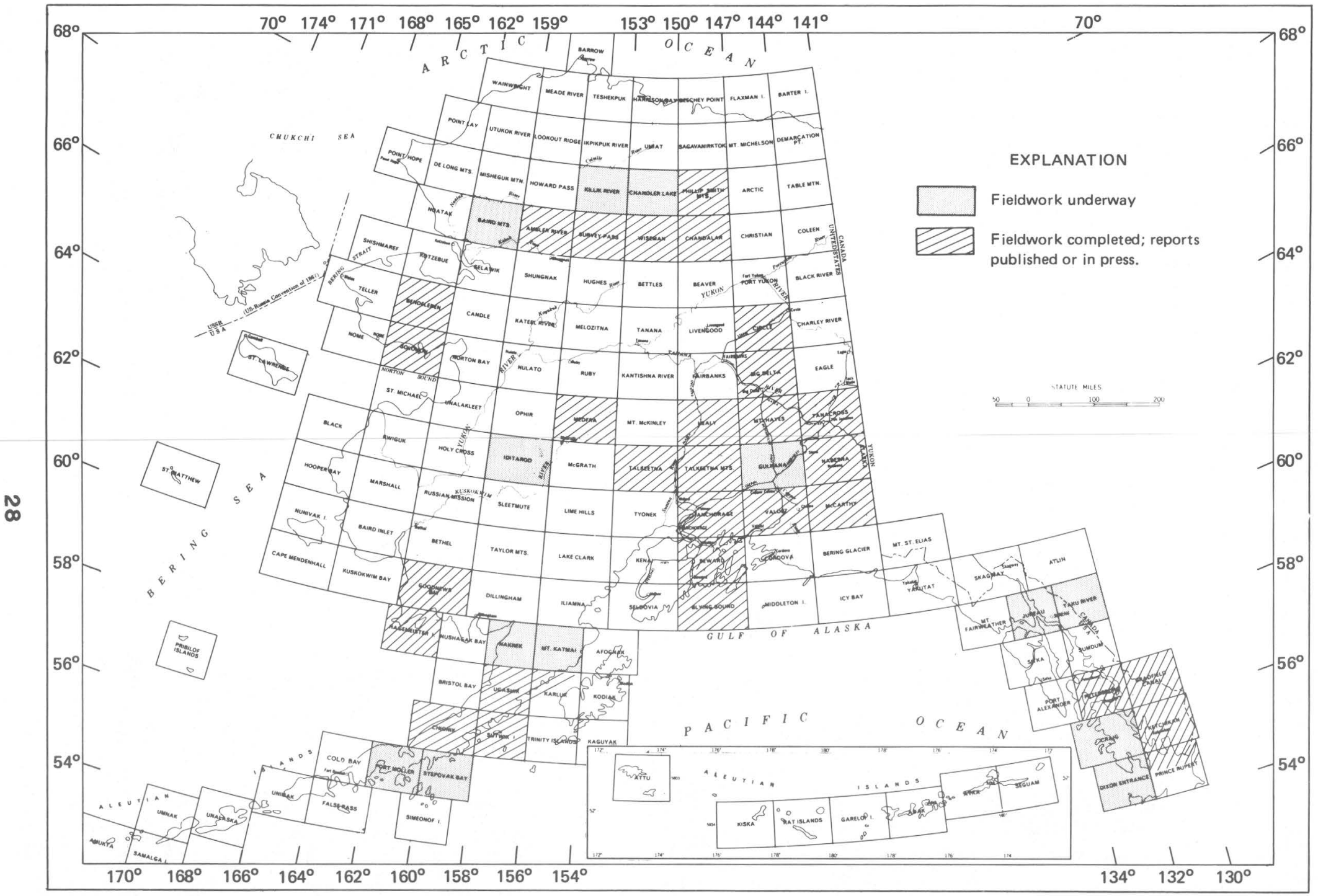

Figure 6.-Status of Level III Alaska Mineral Resource Assessment Program studies, January 1, 1985. 
project being undertaken by the U.S. Geological Survey. TACT is an integrated geologic and geophysical investigation along the corridor that will include extensive seismic refraction and reflection profiling, as well as detailed geologic mapping along a 1.2-mile-wide strip adjacent to the transect. In 1984, the TACT work concentrated on the portion of the corridor that passes from Valdez, through the Chugach Mountains, into the Copper River Basin, and through the Alaska Range to the Denali fault.

Although all fieldwork has been completed on areas recommended for wilderness status in Alaska, several notable reports about these areas were published in 1984. These included the final report on the Tracy Arm-Fords Terror area of southeastern Alaska (U.S. Geological Survey and U.S. Bureau of Mines, 1984) and the final mineral resource assessment for the Chugach National Forest in Prince William Sound (Nelson and others, 1984). Also in 1984, the Geological Survey and the Bureau of Mines published a comprehensive summary of their wilderness work in the United States from 1964 to 1984, which included summaries of all the Alaskan work to date (Marsh and others, 1984).

Bureau of Mines.-Five Bureau of Mines programs provide information about the nonfuel mineral potential of Alaska: (1) Mineral Land Assessment Program (MLA) (2) Mineral Availability Program, (3) Policy Analysis Program, (4) State Mineral Specialist, and (5) Critical and Strategic Minerals Program. The accomplishments of these programs in 1984 are summarized below.

Mineral Land Assessment Program work completed in 1984 included the publication of several reports about mineral resources in the Chugach National Forest, the Bureau of Land Management's Iditarod-George Planning Block, and the Kantishna Hills/Dunkle Mine study areas. Reconnaissance fieldwork and bulk sampling of placer and lode deposits in the Juneau, Valdez Creek, Willow Creek, and Yentna mining districts was done as part of the Bureau of Mines' mining district studies. Figure 5 shows areas of Bureau MLA activities; see also table 4.

The Chugach National Forest study was part of the Roadless Area Resources Evaluation II program. Fieldwork was completed in 1982, and several Bureau and joint Bureau-U.S. Geological Survey reports have been released. Preliminary reports detailing Bureau investigations of gold, molybdenum, copper, and manganese occurrences were published from 1979 to 1982; these are listed in previous annual ANILCA reports in this series. Mineral occurrences in the Chugach National Forest have been summarized by the Bureau in Jansons and others (1984), and a joint Geological Survey-Bureau of Mines report describing the geology, geophysics, geochemistry, and the mineral resource potential of the area has also been published (Nelson and others, 1984). The strategic and critical mineral development potential of the Chugach National Forest is described in an open-file report by Hoekzema (1984). Several additional reports detailing lode and placer deposits in the Chugach National Forest are in preparation.

Results of work completed in the Kantishna Hills/Dunkle Mine study area of the Denali National Park and Preserve by contractors and the Bureau of Mines during 1983 have been published in two Bureau open-file reports (DOWL Fingineers/ PLANgraphics, 1984; Salisbury and Dietz, 1984). Information from these reports was incrrporated into the Kantishna Hills/Dunkle Mine stu ly report (Alaska Land Use Council, 1984) and the study for the final environmental impact statement (EIS) for the Denali National Park and Preserve (National Park Service, 1984). A mineral resource study contracted to Salisbury and Dietz, Inc., of Spokane, Wash., identified geologic environments farmissive for large stratiform base and precio's metal mineralization, located 17 new mineral occurrences, and estimated a reserve of 688,000 ounces of placer gold in 43 million cubic yards of gravel in the Kantishna Hills area. Geologic environments permissive for breccia pipe deposits containing gold and porphyry-type deposits of copper and molybdenum were identified in the Dunkle Mine area. Mining feasibility studies by the Bureau surgest that precious metal and antimony veins may be currently economic to mine in the Kantishna Hills area. Regional mineral endowment assessments. made by the Alaska Division of Geological and Geophysical Surveys under contract to the Bureau, suggest the probability of recovering $\$ 375$ million to $\$ 1.2$ billion worth of minerals at 95 percent and 5 percent confidence levels, respectively, from the Kantishna Hills study area and from 0 to $\$ 840$ million worth of minerals at the 95 and 5 percent confiderse levels, respectively, from the Dunkle Mine study area. Fieldwork included regional and detailed geologic mapping, diamond core drilling at some potential lode mine and prospect sites, chemical and geophysical surveys, and placer sampling. DOWL Engineers/PLANgraphics of Anchorag?, under contract to the Bureau, estimated that the cost of acquiring mining claims in the two areas might be as much as $\$ 157,208,000$. For estimatinx the cost of mineral claim acquisition, the mineral estate was considered for both patented and unpatented claims. The additional values of the surface estate were determined for patented claims. T'e studies have aided the Alaska Land Use Council in formulating recommendations to Congress regarding the management of these two areas. A Bureau open-file report by Jeske (1984) describes the regional distribution of critical and strategic minerals in the Kantishna Hills study area, and a report summarizing the results of Bureau placer studies in the area is in preparation.

A report summarizing 1983 Bureau vrork in the Iditarod-George Planning Block has been published 
(Meyer, 1985). Previous data and analytical results from 1983 samples were used to identify mineralized and potentially mineralized areas.

Preliminary studies of the Valdez Creek, Willow Creek, and Yentna mining districts included the examination of 16 lode and 34 placer prospects. Two potentially significant deposits were identified in the Yentna district. A previously unreported zinc-silver occurrence in the Talkeetna Mountains yielded samples containing from 5 to 10 percent zine and as much as 6 ounces of silver per ton. A 300-foot-wide outcrop of banded quartzhematite-pyrite-chalcopyrite in the Talkeetna Mountains yielded samples containing 6 percent copper. Three significant areas of mineralization were delineated in the Valdez Creek mining district, primarily from a literature search: the Chulitna River-Broad Pass area, the Clearwater Mountains area, and the Maclaren River and Glacier area.

The Bureau also worked in the Juneau mining district (Porcupine subdistrict) in cooperation with the Alaska Division of Geological and Geophysical Surveys. Work included examination of gold stockworks and gold vein deposits near McKinley and Porcupine Creeks and sampling and mapping of stratabound massive sulfide occurrences in the Mount Henry Clay area. Reports describing these sulfide occurrences were released in 1984 (Still, $1984 a$, b). This work will continue in 1985 at a significantly expanded level.

The Minerals Availability Program provides a system that stores, updates, and summarizes information about mineral deposits statewide. Four hundred ninety-seven Alaskan properties were entered into the MILS data base as potential mineral producers.

In 1984, complete MAS deposit evaluations were performed on eight Alaskan mineral properties. The evaluations assess the quantity and quality of commodity present, mining and beneficiation technologies, capital and operating costs, and institutional constraints.

Minerals Availability Program activities also include a cooperative study with the Bureau's Policy Analysis section to assess the mineability of selected Alaskan properties containing critical and strategic mineral commodities.

Information about MAS or MILS products (described in the introductory pages of this circular), such as data printouts or computerplotted overlays, can be obtained from the Chief, Alaska Field Operations Center, in Anchorage or from of fices in Juneau and Fairbanks.

Studies under the Policy Analysis Program that are in progress or were recently completed include: (1) an analysis of company camp versus company town in developing Alaska's mineral resources; (2) the preparation of land status maps covering southeast, south-central, and north-central Alaska; and (3) entry into computerized format of sample locations and analytical results from Bureau of Mines field projects in the Chugach National Forest. Computer tapes and printer data will be available for future reinterpretation.

Reports written in 1984 under the aegis of the State Mineral Specialist include the Alaska chapter in the "Minerals Yearbook" and th? annual preliminary "Mineral Industry Survey." Periodic updates are prepared of the "Alaska Mineral Briefing Profile," lists of mineral-related associations and organizations, and of meetings, conferences, and symposia. Commodity survey mailing lists are updated, brief summaries written for visiting officials, and trip guidance is furnished as required. Bureau representation has been provided in preparation of the draft EIS for the Quartz Hill Molybdenum Project Mine Development and other projects as assigned.

As part of the mineral studies mandated under the ANILCA, the Bureau of Mines is evaluating occurrences of critical and strategic minerals. Critical and strategic minerals are trose commodities that are essential to national defense and for which we are dependent on sources outside the United States. The overall objective of the Bureau's program is to locate deposits of these minerals that could be mined, should the need develop for a domestic source. Specific goals include: (1) evaluation of the mineral reserve potential of the metallogenic provinces of Alaska; (2) estimation of the inferred reserve tonnages, as an in-the-ground stockpile, of specific deposits at both economic and subeconomic levels; and (3) beneficiation and metallurgical testing and analyses of potential Alaskan ores containing critical and strateric minerals. Undertaken in 1981, the Critical and Strategic Minerals Program first concentratef on cobalt, platinum-group metals, and chromium. Table 5 summarizes information about Alas'kan chromite deposits. A second phase of the program is now considering occurrences of tin, tantrlum, niobium (columbium), gallium, and germanium. Pertinent reports completed in 1984 are listed $\varepsilon$ t the back of this circular with the Bureau's publications. Table 6 summarizes known occurrences, prospacts, and districts containing tin, tantalum, and (or) niobium; locations are shown on figure 7. Field studies of these and related elements are continu:ng.

Bureau of Land Management.-The Bureau issued eight mineral patents in 1984 for 62 placer mining claims for gold and tin. The area conveyed totals $1,505.421$ acres. These claims are in areas east of Talkeetna, west of McGrath, near Livengood, and near Tin City. (See figure 5 for locations.)

In response to a Bureau request, the U.S. Geological Survey provided information abnut strategic and critical mineral resources in the southern part of the National Petroleum Reserve in Alaska. This information is being used in continuin? analysis of the Reserve to determine if any part of it might be opened to eritical and strategic mineral development as called for in Section 13 of ANI.CA. 
Table 5.-Summary of chromite deposits and estimated reserve potential (Includes only deposits for which estimated reserves or estimated reserve potential is indicated. Additional deposits are summarized in remarks column)

\begin{tabular}{cccc}
\hline Region & $\begin{array}{c}\text { Number } \\
\text { of } \\
\text { deposits }\end{array}$ & $\begin{array}{c}\text { Type of } \\
\text { chromite }\end{array}$ & $\begin{array}{c}\text { Estimated } \\
\text { reserve } \\
\text { potential } \\
\left(\text { tons } \times 10^{3},\right. \\
\end{array}$ \\
& & $\left.\mathrm{Cr}_{2} \mathrm{O}_{3}\right)$ & Remarks \\
\hline
\end{tabular}

\begin{tabular}{|c|c|c|}
\hline $\begin{array}{c}\text { Western } \\
\text { Brooks } \\
\text { Range }\end{array}$ & 70 & $\begin{array}{l}\text { High-chromi um } \\
\text { (metallurgical } \\
\text { grade) }\end{array}$ \\
\hline
\end{tabular}

Numerous deposits and occurrences in the largest known peridotite masses in Alaska. Most deposits are small, but large low-grade zones that contain many smaller, higher grade concentrations exist within $30 \mathrm{mi}$ of proposed road

\begin{tabular}{|c|c|c|c|}
\hline $\begin{array}{l}\text { Yukon- } \\
\text { Koyukuk } \\
\text { trend }\end{array}$ & 9 & $\begin{array}{l}\text { High chranium } \\
\text { and high-iron } \\
\text { (ehemi cal } \\
\text { grade) }\end{array}$ & $\begin{array}{c}17 \text { to } \\
31\end{array}$ \\
\hline $\begin{array}{l}\text { Rampart } \\
\text { trend }\end{array}$ & 4 & $\begin{array}{l}\text { High chromium } \\
\text { and high-iron }\end{array}$ & $\begin{array}{c}17 \text { to } \\
37\end{array}$ \\
\hline
\end{tabular}

Numerous occurrences and several small deposits in 6 areas between 1 and $75 \mathrm{mi}$ from the Dalton highway

Four small deposits, numerous occurrences and placer potential in the Kaiyuh Hills. Chromite in placer concentrates from Little Minook Creek. Chromite in geochemical rock samples from Christian complex. No road access

$\begin{array}{cl}\begin{array}{c}\text { Yukon-Tan- } \\ \text { ana Upland }\end{array} & \begin{array}{l}\text { Inferior qual- } \\ \text { ity chromian } \\ \text { spinel }\end{array}\end{array}$

Large area containing about $3 \%$ high-Al, high-Mg chromite at Nail Ridge and chromite in placer concentration and accessory chromite in serpentinite and serpentinized peridotite from 5 other areas, all within $40 \mathrm{mi}$ of existing roads

\begin{tabular}{|c|c|c|c|c|}
\hline $\begin{array}{l}\text { Alaska } \\
\text { Range } \\
\text { trend }\end{array}$ & 0 & High chromium & 0 & $\begin{array}{l}\text { Accessory chromite in numerous fault- } \\
\text { bounded serpentinite and dunite masses. } \\
\text { Varied access }\end{array}$ \\
\hline $\begin{array}{l}\text { Southwest } \\
\text { region }\end{array}$ & 0 & $\begin{array}{l}\text { Infer ior qual- } \\
\text { ity chromian } \\
\text { spinel }\end{array}$ & 0 & $\begin{array}{l}\text { Accessory chromite in fault-bounded } \\
\text { serpentinized peridotite masses, } 1 \text { zoned } \\
\text { ultramafic complex, } 1 \text { small monzonite } \\
\text { pluton, and adjacent streams and beach } \\
\text { sands. No road access }\end{array}$ \\
\hline $\begin{array}{l}\text { Chugach } \\
\text { trend }\end{array}$ & 69 & High-chromium & 2,800 & $\begin{array}{l}41 \text { hard-rock and } 1 \text { placer deposit, all } \\
\text { within } 10 \text { mi of tidewater or existing } \\
\text { roads. Most reserves are in large, low- } \\
\text { grade ( } 5-10 \% \text { chromite) zones of banded } \\
\text { chromite }\end{array}$ \\
\hline $\begin{array}{l}\text { Southeast } \\
\text { region }\end{array}$ & 9 & $\begin{array}{l}\text { Infer ior qual- } \\
\text { ity to high- } \\
\text { chromium }\end{array}$ & 4 & $\begin{array}{l}\text { Minor chromite in zoned mafic-ultramafic } \\
\text { complexes }\end{array}$ \\
\hline
\end{tabular}

National Park Service.--The Park Service is responsible for approving and monitoring mining and related activities on mining claims on lands administered by the Park Service. The Service approved 37 plans of operation for mining and related activities during 1984 , the majority of which were at Kantishna, in the Denali National Park and Preserve. Most of these operations are for placer 


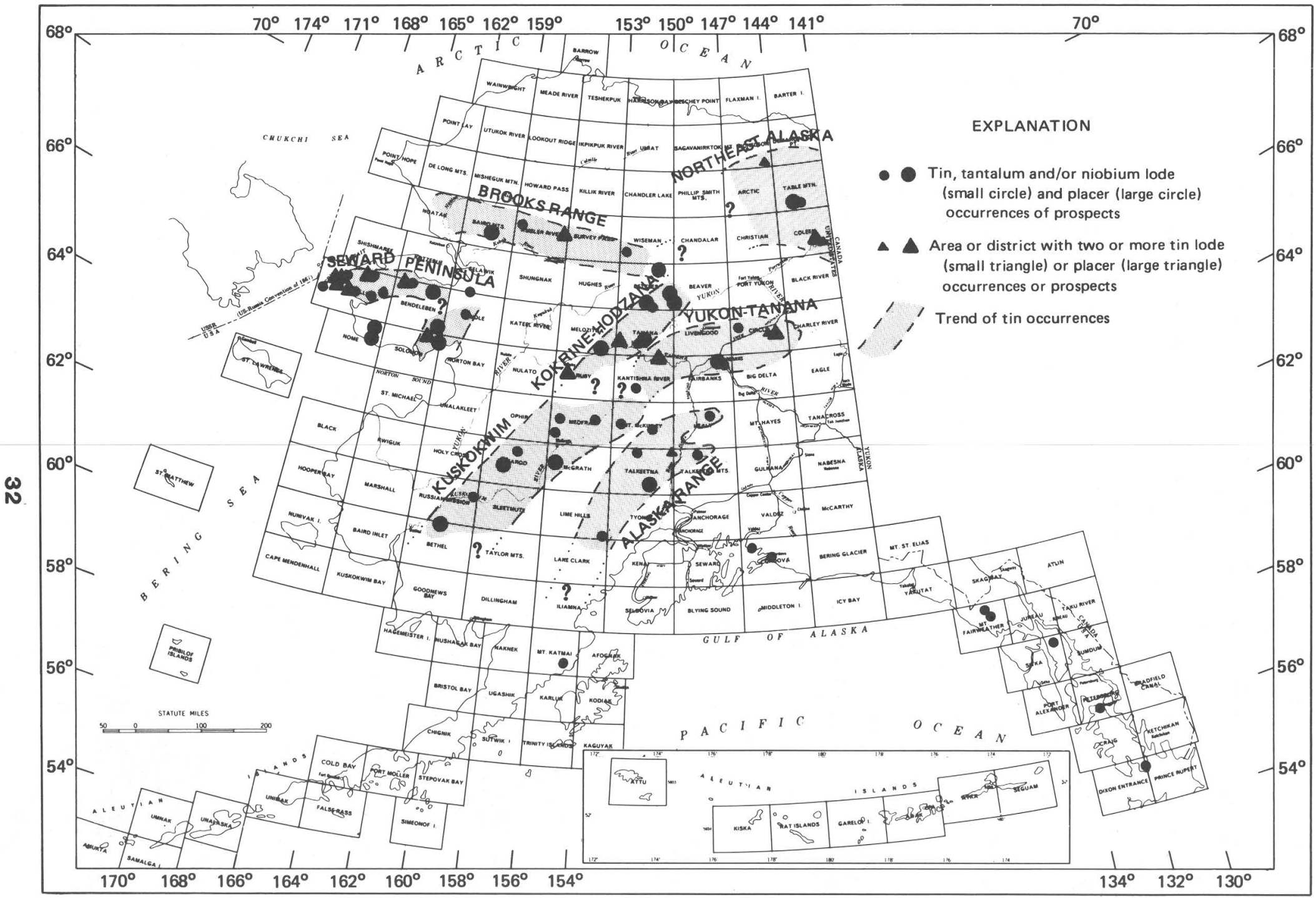

Figure 7.--Tin, tantalum, and niobium occurrences in Alaska. See also table 6. 
Table 6.-Occurrences, prospects, districts or areas containing tin, tantalum, and (or) niobium

\begin{tabular}{ll}
\hline Location & \multicolumn{1}{c}{ Occurrence, prospect, district, or area } \\
\hline Northeast Alaska & $\begin{array}{l}\text { Esotuk and McCall Glacier occurrences, Bear Mountain prospect, Rapid and } \\
\text { Porcupine Rivers area }\end{array}$
\end{tabular}

Brooks Range Unnamed central Brooks Range occurrences, Kaluich occurrence, Kiana occurrence, Gold Bench occurrence

Seward Peninsula Selawik Hills area, Ear Mountain area, Potato Mountain area, Cap Mountain area, Black Mountain occurrence, unnnamed central Seward Peninsula occurrence, Kougarok prospect area, Hannum Creek occurrence, Otter Creek occurrence, Monument Creek occurrence, Rocky Mountain occurrence, Omalik and Vulcan Creek area, Granite Mountain area

Kokrine-Hodzana Hogatza occurrence, Sithylemenkat area, Hot Springs pluton, Fort Hamlin Hills pluton area, Quartz Creek prospect, Tozimoran and Ash Creek area, Mrson Creek mine, Morelock and Bonanza Creek prospects, Ruby-Long mining district

Yukon-Tanana Circle mining district, Lime Peak prospect, Fairbanks mining district, Tofty tin belt, Cosna prospect

Kuskokwim Win prospect, Won prospect, Mystery Mountain area, Telida Mountain a"ea, Winasale Mountain area, Beaver Mountains area, Malemute Creek occurrence, Russian Mountains occurrence, Marvel Creek occurrence

Alaska Range Sheep Creek prospect, Kantishna mining district, Chulitna mining district, Tsusena Creek prospect, Boulder Creek prospect, Yentna mining district, Tired Pup area

Other locations $\quad$ Valley of Ten Thousand Smokes occurrences, Copper Mountain occurrence, F'ide River occurrence, Tarr Inlet Knob occurrence, Johns Hopkins Inlet occurrence, Edelweiss prospect, Salmon Bay prospect, Bokan Mountain prospect

gold, although there was some extraction of small quantities of silver and some interest in other minerals.

The Park Service cooperated in studies and EISs for the Denali National Park and Preserve and in the Cape Krusenstern National Monument where proposed mining activities and access to mining activities will impact Service lands. The Park Service also cooperated in a possible land exchange involving lands in the Cape Krusenstern National Monument that contain an access route to the proposed Red Dog mine in northwestern Alaska. Cominco Alaska, Inc., proposes to extract the lead-, zinc-, silver-, and barite-bearing minerals by openpit mining and to transport them across the northwest corner of the Cape Krusenstern National Monument to a potential port on the Chukchi Sea.

U.S. Fish and Wildlife Service.-In keeping with the Service's primary mission, its major efforts relating to mineral activity in Alaska have emphasized fish, wildlife, and habitat protection. However, about 1,200 mining claims and 425 millsite claims located before passage of ANILCA are recorded in thirteen of Alaska's National Wildlife Refuges (NWRs). Of these, about 800 claims, mostly lode claims, were known to retain active filing status as of March 1985; most are in the Togiak, Yukon Flats, and Alaska P nninsula refuges. Mineral survey application is filed for $\mathbf{4 0}$ placer claims in the Togiak NWR near Gondnews; survey approval and subsequent patent apflication are expected by late 1985 . Mineral survey application also remains on file for seven lode c'raims in the Alaska Maritime NWR near the Apollo mine on Unga Island.

In April 1984, a revised draft of the Bristol Bay Cooperative Management Plan and draft EIS were issued. Following public review, the State of Alaska withdrew from the cooperative plar and in September adopted an area plan involving Bristol Bay State lands. The Fish and Wildlife Service is continuing to develop the final plan and an EIS for the Bristol Bay region; the report is sched led for release in 1985 .

The Fish and Wildlife Service cooperated with the Department of Agriculture-Forest Se"vice in preparing an EIS for the Quartz Hill mine development plan and continued to provide technical assistance for instream flow studies on Wilson River and Tunnel Creek in support of the mins water 
supply plan. The Fish and Wildlife Service also continued to assist the Forest Service with the plans of Noranda Mining, Inc., for mining at Greens Creek.

The Environmental Protection Agency and the Department of the Interior (1984; see also "Other Federal agencies" in the selected references at the back of this circular) have prepared a Final EIS on the proposed Red Dog inine. Cominco Alaska, Inc., has filed a consolidated ANILCA Title XI application with the Department of the Interior, Environmental Protection Agency, and the Corps of Engineers for Federal permits required for the development of the proposed transportation system.

The Fish and Wildlife Service co-authored with the National Park Service a report (West and Deschu, 1984) about the 1983 sampling of water, stream sediments, and fish tissue for toxic heavy metal content in the Kantishna Hills area of the Denali National Park and Preserve. Results reinforce previous findings that arsenic and mercury contents in water and fine sediment are higher downstream of placer mines than upstream, although the data were not treated statistically. Arsenic and mercury were also present in greater quantities in the tissues of fish taken downstream of placer mines. Although the parts customarily eaten by humans were judged safe, liver and gill abnormalities were predicted to be more likely in grayling in mined streams. The high cost of fish tissue analyses, however, precluded work with statistically adequate numbers.

Samples were also taken of surface water, stream sediment, and fish from the Tuluksak River (fig. 8) in the Yukon Delta NWR. These samples were submitted to the Fish and Wildlife Patuxent River Wildlife Research Center for determinations of heavy-metal concentrations. The Service also provided comments recommending special permit conditions to the Corps of Engineers on a permit application by Northland Gold Dredging for a major placer mining operation on the Tuluksak River adjacent to the Yukon Delta NWR.

Department of Agriculture-Forest Service.-One of the large mining developments in southeastern Alaska, Greens Creek, is in the Tongass National Forest. Noranda Mining, Inc., requested a Forest boundary adjustment to facilitate exploration of the ore body and thus minimize environmental impacts. The Forest Service has issued a final EIS about the proposal and continues to monitor mitigation of impacts. The boundary decision was still pending as of March 1985. More information about this issue is given under the heading "Industry hardrock activity in base metals."

U.S. Borax and Chemical Company's Quartz Hill molybdenum deposit is in the Misty Fiords National Monument on claims in a 152,000-acre tract that is not classified as wilderness. The Forest Service was the lead agency in the preparation of the draft EIS that considers the mine development plans. This report wes released in 1984; preparation of the final EIS is under way. Further information about the Forest Service activity at Quartz Hill is given under "Industry hardrock activity in base metals."

\section{STATE ACTIVITIES}

The Alaska State Administration and Legislature continued to encourage dovelopment of the mining industry in Alaska by designating funds to support roads and other infrastructure costs for mines being developed; the Red Drg deposit in northwestern Alaska is the most prominent current example. The State has also subsidized loans to placer miners for mining equipment and equipment needed to meet water-quality stantards, and it provided funds for educational projects. In addition, it has assumed an activist role in assuring that mining interests are fairly represented in various governmental and land-use planning bodies. Much of this activity is carried on under the auspices of the Division of Mining, created in 1983 as part of the Department of Natural Resources (Anchorage Daily News, April 22, 1984).

In December of 1984, the Alaska Division of Geological and Geophysical Surveys and the U.S. Geological Survey jointly established a Geologic Materials Center at Eagle River near Anchorage. The center stores and catalogues core and geologic samples from oil and gas wells, as wall as samples collected during mineral exploration. This central repository will insure that these samples, which might otherwise be unavailable or destroyed, can be made accessible to governmental agencies and industry in perpetuity. In particular, the Center contains all the core samples from the holes drilled on the National Petroleum Reserve in northern Alaska from 1944 to 1953 and durir exploration from 1975 to 1981 . The center is operated by the DGGS, and facilities are available to the public for viewing and studying the samples.

During the year, the Division of Geological and Geophysical Surveys published a concise summary of Alaska's mineral, energy, soil, timber, and archeological resources, as well as information about the Department of Natural Resources' programs that are designed to better inventory these resources (Barnwell and Pearson, 1984). Another significant summary, one of an annual series, "Alaska's Mineral Industry, 1984," was also prepared by the Alaska Office of Mineral Development (Eakins and others, 1985). The State issued a revised edition of its listing of mining companies and miners (Alaska Division of Geological and Geophysical Surveys, 1985).

Controversy continued over the restrictions to be placed on mining in the Kantishna Hills area of the Denali National Park and Preserve. The Alaska Land Use Council, which was empowered to study future mineral development in the area by ANILCA, recommended to Congress that the arsa be open to 
mineral leasing. This recommendation represents a carefully worded compromise by the members of the council, which includes representatives from the Alaska Department of Natural Resources, the National Park Service, and other agencies. Environmental groups strongly oppose opening the area to new mining; objections have also arisen from within the Department of the Interior. In late 1984 the issue was in the hands of the Secretary of the Interior, who will make a decision on the recommendations to be sent to Congress (Anchorage Times, May 24, June 3 and 4, 1984).

An issue that became prominent in 1984 involves the conditions under which the State of Alaska will allow miners to operate on State land. The State currently uses a claim system to allow access to State lands for purposes of mining and mineral exploration and charges only a nominal tax on mineral production. A coalition of several environmental and Native groups has charged that the State is delinquent in not instituting a leasing system for metallic minerals on State land. The groups feel that such a leasing system is required under the Alaska Statehood Act and point out that a leasing system is presently used for oil and gas, coal, and sand and gravel on State land. About 45,000 State mining claims are involved. Miners have suggested that imposing a leasing system on State land is an attempt to hamper mineral exploration and mining by imposing an undue financial burden on an already financially troubled industry (Anchorage Daily News, Feb. 3, 1984; Petroleum Information, Alaska Report, Nov. 28, 1984).

\section{INDUSTRY HARDROCK ACTIVITY}

\section{IN BASE METALS}

Three major deposits-the Red Dog zinc-leadsilver deposit in northwestern Alaska, the Greens Creek base and precious metal deposit on Admiralty Island in southeastern Alaska, and the Quartz Hill molybdenum deposit near Ketchikan in southeastern Alaska-moved steadily toward production and were frequently in the news and economic reports during 1984. The following discussion updates information that appeared in the previous annual ANILCA minerals reports.

Numerous other mineral deposits were mentioned in the professional literature or in the press; figure 8 shows the locations and table 7 gives further descriptions of these deposits, which are briefly discussed later in this section.

Red Dog.-The Red Dog deposit in the De Long Mountains of northwestern Alaska (fig. 8) continues to figure prominently in the press and trade journals. It may become the first large Alaskan mine to go into production in several decades. Little new information has been published about the geology and reserves of the deposit in the past year. The emphasis has shifted from definition of a deposit worthy of development to the long, expensive, and often uncertain process of putting the deposit into production.

The Red Dog effort is a joint venture between Cominco America, Inc. (a U.S. subsidiary of Cominco Ltd., the Canadian parent), and tre NANA Regional Corporation, which is based in Votzebue and is one of the 12 regional Native corporations set up by the Alaska Native Claims Settlement Act of 1971. By the terms of their 1982 agpoement, Cominco will finance the development of the deposit and operate the mine, and NANA nill share the profits and become an equal partner in the property after the initial investment is recovered (Western Miner, April 1984, p. 21-22). The drilling to date has defined 85 million tons of material with a grade of 17.1 percent zinc, 5.0 percent lead, and 2.4 ounces of silver per ton. The deposit is already one of the largest zinc resources in the n'orld and has a particularly high grade for such large tonnage. Although the Red Dog deposit is located in Arctic Alaska, it is relatively accessible over land largely controlled by NANA, it can be easily mined by a surface pit, and the ore is amenable to current metallurgical technology.

Work continues at Red Dog on various fronts. Probably the least publicized are the technical aspects of building the mine plant, mill, roads, living facilities, and other infrastructure. Following practice established in developing the North Slope oilfields, much of the mine and mill plant हnd other facilities would be constructed in modules outside Alaska and shipped in by ocean transport to northwestern Alaska. Construction time has been estimated at 2 to $21 / 2$ years (Western Miner, April 1984 , p. 21-22). Several engineering projects have recently been announced. The firm of $D \varepsilon$ mes and Moore has been hired to design two dams that will store mine tailings and furnish drinking water to the camp. Cominco also signed drilling contracts in 1984 with NANA-Coates Diamond Drilling, Inc., and Interstate Exploration, Inc. (Anchorage News, Aug. 1, 1984).

Cominco has estimated that the development of the deposit into a mine will require $\$ 300-350$ million. They also estimate that the mine life (based on current reserves) is about 50 years (Anchorage Times, Sept. 16, 1984). However, in the last year, the price of zinc has been depressod; as of April 10, 1985 , it was $\$ 0.45-.47$ per pound. Cominco also estimated that an average price of about $\$ 0.70$ per pound (without any State investment) will be necessary to recover their total costs over the life of the mine and insure an adequate return on their investment (Anchorage Times, Sept. 15, 1984). A similar study by the State of Alaska in the spring of 1984 concluded that an average zine price of about $\$ 0.63$ per pound will be necessary to assure Cominco a 15-percent return on its investment over the life of the mine (Alaska Economic Report, March 25, 1984). The depressed zinc price caused Cominco, the world's largest zinc producer, to close two of its 


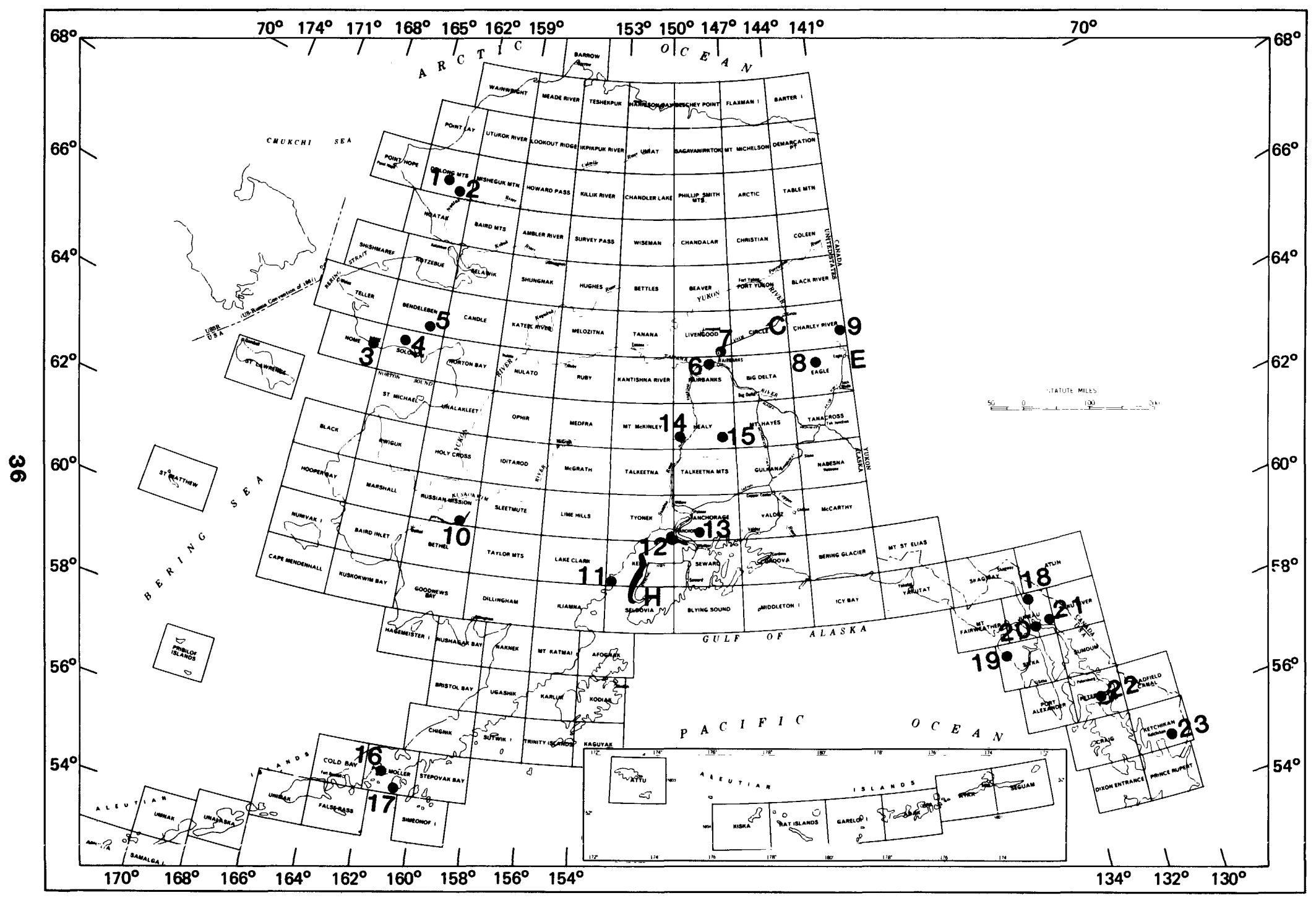

Figure 8.--Areas of important industrial activity for nonfuel minerals; see table 7 for identification of numbered areas and commodity of interest. 
Table 7.-Areas of industry activity for nonfuel minerals; locality numbers taken from figure 8

\begin{tabular}{|c|c|}
\hline $\begin{array}{l}\text { Area } \\
\text { number }\end{array}$ & Activity \\
\hline 1 & Lik zinc-lead silver prospects \\
\hline 2 & Red Dog zinc-lead-silver prospect \\
\hline 3 & $\begin{array}{l}\text { Nome gold dredges; submarine } \\
\text { gold placers off Nome }\end{array}$ \\
\hline 4 & Big Hurrah gold mine \\
\hline 5 & $\begin{array}{l}\text { Silver-lead-zinc prospects near } \\
\text { Omalik }\end{array}$ \\
\hline 6 & $\begin{array}{l}\text { Grant gold mine, Fairbanks } \\
\text { district }\end{array}$ \\
\hline 7 & $\begin{array}{l}\text { Fairbanks gold-tungsten-silver } \\
\text { prospects }\end{array}$ \\
\hline 8 & Eagle asbestos prospect \\
\hline 9 & Step Mountain zinc-lead prospects \\
\hline 10 & Tuluksak River placer gold mine \\
\hline 11 & $\begin{array}{l}\text { Johnson River gold-zinc-lead- } \\
\text { copper prospects }\end{array}$ \\
\hline 12 & $\begin{array}{l}\text { Cook Inlet submarine placer gold } \\
\text { prospects }\end{array}$ \\
\hline 13 & Crow Creek gold mine \\
\hline 14 & Golden Zone gold mine \\
\hline 15 & Valdez Creek placer gold mine \\
\hline 16 & Canoe Bay gold prospects \\
\hline 17 & Alaska Apollo gold-silver mine \\
\hline 18 & Berners Bay gold-silver prospect \\
\hline 19 & Chichagof gold mine \\
\hline 20 & $\begin{array}{l}\text { Greens Creek zinc-lead-copper- } \\
\text { silver-gold prospect }\end{array}$ \\
\hline 21 & $\begin{array}{l}\text { Alaska-Juneau and Treadwell } \\
\text { gold mines }\end{array}$ \\
\hline 22 & $\begin{array}{l}\text { Zarembo Island gold-base metals } \\
\text { prospect }\end{array}$ \\
\hline 23 & $\begin{array}{l}\text { Quartz Hill molybdenum } \\
\text { prospect }\end{array}$ \\
\hline $\mathrm{C}$ & Central \\
\hline $\mathbf{E}$ & Eagle \\
\hline $\mathbf{H}$ & Homer area (gravel source) \\
\hline
\end{tabular}

major western Canadian zine mines for short periods in the winter of 1984 while the price of zinc firmed.

Higher zinc prices are likely in the future (allowing for considerable uncertainty in that they are largely a reflection of the future world economy and world production) if only because of the historic low zinc price and the eventual effects of the improvement of the economy over the last several years, effects that are notoriously slow to reach the mining industry. However, it is considerably more dif ficult to finance and develop a $\$ 350$-million mine during a period of low zinc prices than in a period of relatively high prices. Whatever the uncertainty in forecasting future zine prices, Cominco has stated (Anchorage Times, Sept. 16, 1984) that the development of the Red Dog deposit is an important key to maintaining their international position as a major zinc producer into the next century.

Although the most practical access road to the deposit from the coast is mainly over NANA lands, part of the route lies in the Cape Kru-enstern National Monument that was established by ANILCA in 1981 and is closed to development and mineral exploration. In early 1984, the NANA Corporation worked out a tentative agreement with the Department of the Interior to acquire 65,000 acres of land in the Monument that would be used for access to the Red Dog deposit and, in return, relinquish their rights to select about 63,010 acres of land in the Monument and transfer about 1,300 acres along the coast to the National Park Service. The agreement has been subject to several reviews and public meetings, and the National Part Service has indicated that a final agreement between them and NANA is near. However, the Sierra Club was considering a lawsuit to block the trade on the grounds that such land trades that primarily benefit resource development are not permitter under ANILCA. In late 1984, the Environmental Protection Agency (EPA) and the Department of the Interior made Congressional approval for the rightof-way permit the preferred alternative ir the EIS for the land trade because of the probable long delay if court action takes place ( $P$ :troleum Information, Alaska Report, Nov. 28, 1؟94). In February of 1985, the Alaska Congressional delegation submitted legislation to ratify the land exchange; the exchange is supported by the State's Land Use Council and at least one major environmental group (Anchorage Daily News, Feb. 9, 1985). Also in February 1985, the U.S. Corps of Engineers issued permits for the proposed road and port, a major hurdle in the long route to construction (Anchorage Daily News, Feb. 8, 1985).

The development of the Red Dog denosit has led to boundary negotiations between the NANA corporation and the city of Kotzebue on the one hand, and with the North Slope Borough based at Barrow on the other. When the North Slope Borough was established in 1972, it included the arsa of the Red Dog deposit (whose value was then unknown). Now, the NANA corporation would like to establish a borough based in Kotzebue, but that governmental body would probably not have a sufficient tax base to maintain a regional government unless the Red Dog mine were within its boundaries. The president of NANA also indicated that the taxation policy of the North Slope Borough and the governmental jurisdiction over the Red Dog deposit may be factors in NANA's continuing commitment to developing it (Anchorage Daily News, April 26, 1984).

The present depressed price of zinc and the desire of the participants to initiate production in the near future has led to negotiations between Cominco and the State of Alaska over the possibility of State investment in the project. The company seeks to have the State commit funds for 
the 57-mile access road to the deposit and for port facilities. The main advantage to Cominco would be a considerable decrease in its financial burden to develop the deposit, an advantage that would be particularily helpful considering the present low zine prices. The main advantages to the State would be: (1) an expeditious increase in the number of jobs available in northwest Alaska, an area of chronic high unemployment; (2) diversification of the economy of Alaska beyond the petroleum industry; and (3) ultimately, a return in taxes greater than the amount of the loan (Anchorage Times, Feb. 6, 1985). In mid-February 1985, a Cominco report indicated that the mine, when in full operation, would generate about $\$ 100$ million per year for the State's economy (Anchorage Daily News, Feb. 17, 1985). The State admininstration was favorably inclined toward such a loan (Anchorage Daily News, Sept. 7, 1984). In February 1985, with the legislature in session and in anticipation of declining oil revenues, Cominco proposed a $\$ 150$-million State investment repayable over a 30-year period; the State would receive about $\$ 260$ million in user fees over the life of the investment, and repayment would proceed independently of a production schedule (Anchorage Daily News, Feb. 17, 1985; Anchorage Times, Feb. 19, 1985), State investment in the Red Dog deposit is a sensitive issue and has been a matter of debate in the legislature during 1985.

In late 1984, the Alaska Industrial Development Authority (AIDA) signed a letter of intent to fund the road and port facilities for the Red Dog mine, with repayment through user fees (Petroleum Information, Alaska Report, Jan. 3, 1985). One recent proposal is that, rather than seeking appropriated funds yearly through AIDA, AIDA would establish loan reserves to leverage private capital for the project (Alaska Economic Report, Jan. 28, 1985).

In pursuing State interests, the Administration has cleared a $\$ 3$ million contract to Cominco to study port development and road access. Cominco plans to contribute its considerable engineering data to the study and will subcontract to a previously uninvolved consulting firm for the analysis of the data (Anchorage Times, Sept. 26, 1984; Anchorage Daily News, Oct. 10, 1984).

The activity at Red Dog has also spurred interest in several nearby, similar deposits, notably the Lik deposit being explored by GCO Minerals Company. From 1977 to 1983 GCO drilled more than 90 drill holes and defined 24 million tons of rock containing about 8.8 percent zinc, 3.0 percent lead, and 1.2 ounces of silver per ton. Drilling in 1984 indicated substantial additional mineralized rock in a northern extension of the deposit, but reserve calculations will require additional drilling. Analysis of material from one hole indicated values of 8.9 percent zinc, 3.5 percent lead, and 2.3 ounces of silver per ton over 174 feet
(Alaska Economic Report, March 25, 1984; Alaska Daily News, Nov. 10, 1984; Petroleum Information, Alaska Report, Nov. 14, 1984). The I.ik deposit and others known nearby will undoubtedly be considerably more attractive if the Red Dog deposit is mined and a road connects it to a port on the coast. A road into the area will also stimulate additional exploration for new deposit?

The EPA issued its final EIS for the Red Dog mine project and called for comments by November 18,1984 . Hearings on the draft EIS in the spring of 1984 in Anchorage had produced generally favorable comments (Petroleum Information, Alaska Report, May 9, 1984). The EPA also annourned tentative plans to issue a water discharge permit for the proposed port for the Red Dog mine to be built approximately 17 miles southeast of Kivalina.

Greens Creek.-Work at the Green- Creek zinclead-copper-silver-gold deposit on northeastern Admiralty Island (fig. 8) continued steadily. The deposit is being explored by Noranda Mining, Inc., the operating partner that holds the property jointly with Anaconda Minerals, the Bristo' Bay Native Corporation, Exalas Resource Corporation, and Texas Gas Exploration Company. In 1984 Noranda built a barge-loading dock and ramp on the coast near the deposit, and it is seeking a pemmit for a 14mile road from the dock to the deposit. The deposit is at least 3 to 4 years away from production. About 5 million tons of material have been outlined with a grade of about 10 percent combined zinc, lead, and copper; 12 ounces of silver per ton; and 0.16 ounce of gold per ton. An announcement in Petroleum Information's Alaska Ref ort (Nov. 7, 1984) noted that drilling in the summer of 1984 indicated that the deposit is larger and richer at depth and that its base has not yet been reached.

The Department of Agriculture-Forest Service has recommended withdrawal of 17,000 acres in the Greens Creek drainage from the Admiralty Island National Monument to facilitate the development of the deposit. About 18,000 acres nearby would be substituted for the withdrawn acreage. The land exchange issue is ccmplicated by a December 1985 deadline for Noranda to finish exploration in the areas adjacent to its proven claims. Environmental groups objact to this exchange on the basis of the precedent it would set in allowing agencies to make arministrative boundary changes. They suggest rather that Congress extend the deadline for exploration (Anchorage Daily News, Jan. 4, 1985).

Quartz Hill.-Work on the Quartz Hill molybdenum deposit near Ketchikan in southeastern Alaska (fig. 8) continued persistently in the face of a depressed molybdenum market. The U.S. Borax and Chemical Company, which owns the property, has already spent more than $\$ 100$ million there and is well into the process of obtaining the necessary permits and environmental reviews and coordinating with local, State, and Federal governmental 
agencies. Work at the deposit itself was restricted to environmental monitoring in 1984.

The very size of the Quartz Hill deposit and its probable impact on the world molybdenum production may pose a marketing problem in the future. At the tentatively planned production rate of 60,000 tons per day, the Quartz Hill mine would produce an equivalent of about 122 percent of the current U.S. production. Although molybdenum prices may well improve with increased demand brought on by a continued favorable world economy, several other companies with large molybdenum mines and well explored deposits will be aggressively vying for an improved molybdenum market (Alaska Economic Report, Feb. 16, 1984). U.S. Borax has indicated that construction of the mine could start in 1985 , with initial production in 1988 but that a decision on whether to proceed hinges on the molybdenum market (Petroleum Information, Alaska Report, July 25, 1984).

The Quartz Hill deposit is huge: 1.5 billion tons of material with a grade of 0.136 percent molybdenite has been defined, of which about 300 million tons with a grade of 0.2 percent molybdenite are easily accessible from the surface. In 1984, tests of bulk samples confirmed the assay data provided by diamond drilling and outcrop sampling.

In July 1984, the Forest Service released the draft EIS for the proposed Quartz Hill mine. Many of the controversial issues had previously been worked out by U.S. Borax and the Forest Service. However, U.S. Borax has since asked that the State and the Forest Service approve a plan to dump the tailings from the mine in the Wilson Arm area rather than in Boca de Quadra as was previously arranged with the Governor of Alaska in 1982. A site in Boca de Quadra is preferred in the Forest Service's EIS, but both sites were considered to be useable without adverse consequences to fisheries habitat. The issue is controversial, but use of the Wilson Arm site could mean that the cost of producing molybdenum could be reduced by as much as $\$ 0.50$ per pound (Anchorage Times, Sept. 9,1984 ; Anchorage Daily News, Sept. 20, 1984; Alaska Journal of Commerce and Pacific Rim Reporter, July 24 and 30, 1984; Alaska Economic Report, Oct. $9,1984)$. The draft EIS was being circulated in late 1984, and public meetings were being scheduled. The final EIS will probably be submitted by June 1985 (Alaska Construction and Oil, July 1984, p. 22; Anchorage Daily News, Oct. 4, 1984).

Data in the draft EIS indicated that the effect of the mine on the Ketchikan Borough would be enormous. The work force, which would probably be housed in Ketchikan, would be about 1,800-2,000 people, thus increasing the total borough population by about 3,000. Much new housing would be needed, and the city would be required to greatly expand its public services, including recreational facilities, waste disposal facilities, roads, marine facilities, fire protection, schools, water supply, and law enforcement, among others. The Borough would receive about $\$ 67$ million in revenue per year from the mine, and the mine would reduce some of the high unemployment of the area (Anchorace Daily News, July 25, 1984.)

Other Industry Activites in Base Metals.-In contrast to the last several years, exf loration primarily for base metals was limited, and reports of new discoveries in the press were few. Work continued at many base-metal properties cited in previous ANILCA annual reports or in the recent popular press or professional literature, but without much fanfare. The lack of activity is related to the dramatic downward shift in metal prices eited previously.

In one of the few new discoveries announced in 1984, Northgate Exploration Comprny has identifed several zinc-lead propects nesr Step Mountain, about $\mathbf{5 0}$ miles north of Eacle (fig. 8)(Western Miner, May 1984, p. 23).

\section{INDUSTRY HARDROCK ACTIVITY IN PRECIOUS METALS}

Unlike the situation in base metals, precious metal exploration in Alaska during $19^{\circ} 4$ was extensive. Many new mineral deposits were announced, and many previously known deposits were being reexamined. In the face of the grim price situation for base metals, many, if not most, of the companies exploring for metals in Alaska have turned to gold and silver primarily berause of the relatively high price of gold and, to perhaps a lesser extent, the high price of silver. While the price of gold dropped slowly to about $\$ 308$ per ounce at the end of 1984, precious metels were nearly the only nonfuel mineral commodities that posted prices well above their historic averages over the last 50 years. They also are commodities that have intrinsic value in themselves, are readily saleable now, and will be so for the fonseeable future. Locations of the deposits are shown in figure 8.

Cornwall Pacific Resources Ltd., as a partner with Anaconda Minerals Company, carried out extensive exploration at the Big Hurrah mine on the Seward Peninsula under the direction of C. C. Hawley and Associates. Five steeply dippin : quartz fissure veins have been identified there; these have gold contents generally varying from 0.25 to $\mathbf{0 . 6}$ ounce of gold per ton. About 300,000 tons of material averaging approximately 0.3 ounce of gold per ton has been identified in an area suitable for open pit mining. The 1984 exploration program included further work on the potential onen pit, metallurgical bulk sampling, and additional core drilling and trenching on the veins (Westerm Miner, April 1984, p. 22).

Jonpol Exploration, Onaping Resources, and New Strategic Metals, Inc., have taken an cotion on a 289-claim property near the old Omalik mine in the Darby Mountains on the Seward Penins 'la from 
Greatland Exploration, Ltd. The values at the property are chiefly in silver, lead, and zinc (Northern Miner, March 1, 1984).

Work was in progress to put the Grant gold mine near Fairbanks into production. The property is owned by Silverado Mines Ltd., who have identified more than a million tons of reserves in a mineralized structure 4,000 feet long. Work since 1978 suggests that the average grade of the ore is between 0.60 and 0.80 ounce of gold per ton. Additional drilling and drifting was completed in late 1984; this will be followed by development of the property and mill construction. Production was expected to begin in 1985 (Fairbanks Daily News Miner, Sept. 13, 1984).

Nerco Minerals Company and Hecla Mining Company recently entered into an agreement to explore an area of about 14,000 acres north of Fairbanks that show encouraging signs of mineralization. The target is a gold-tungsten deposit with silver values that could be mined by open pit (Fairbanks Daily News Miner, July 31, 1984).

Several talks about Alaskan gold deposits were presented at the 1984 Alaska Miners Meeting. C. C. Hawley (1984) described the results of recent work on the Golden Zone mine in the Chulitna district of central Alaska. Rainer Newberry (1984) presented an overview of gold skarns in southern and southeast Alaska. A dozen gold skarn deposits have been productive or have reserves in this area, and more than 100 additional gold skarns are known there, but their tonnage and grade cannot be measured with available data.

Anaconda Minerals Company announced a major new discovery of base and precious metal veins in the Johnson River area on the Alaska Peninsula in February of 1984. Two core drills were in operation during the summer of 1984, and while the data are too sparse to make tonnage and grade calculations, some very high values were noted in the drilling. One hole passed through 150 feet of material with a grade of 0.6 ounce of gold per ton, 9.4 percent zinc, 2.8 percent lead, and 1.5 percent copper (Alaska Construction and Oil, July 1984, p. $22,24)$. The Johnson River property is on land owned by the Cook Inlet Region, Inc., but it is surrounded by the Lake Clark National Park. An easement was obtained to the area when the property was originally transferred to the Cook Inlet Region, Inc. However, mining near the Park is of concern to the National Park Service and several environmental groups. While no overwhelming impediments now appear to bar eventual mining, future plans will require coordination between Anaconda and the Federal government (Anchorage Times, Feb. 24, 1984).

Resource Associates of Alaska, a subsidiary of Nerco Minerals Company, signed an agreement with Freeport Exploration Company to examine properties held by Nerco on State and Aleut
Corporation lands near Canoe Bay on the Alaska Peninsula (Petroleum Information, Alaska Report, May 23, 1984).

Alaska Apollo Gold Mines announced that reserves on its property on Unga Island now total more than 600,000 tons with an estimated grade of 0.3 ounce of gold per ton and 1.0 ounce of silver per ton. The mineralization has been dafined along a vein 2,000 feet long to a depth of 400 feet; an additional 7,000 feet of the vein has yet to be tested. Results of recent metallurgical tests have been encouraging, and the owners beran collecting data for an EIS (Northern Miner, March 1, 1984). Alaska Apollo also signed a letter of intent to acquire 51 percent of the mineral rights held by Teton Exploration Drilling Inc. on Un?a, Popof, and Korvin Islands. Teton has spent more than $\$ 3.4$ million drilling on these islands siner 1979 (Alaska Construction and Oil, July 1984).

The Windy-Craggy gold-copper-cobalt deposit in British Columbia was discussed in the 1984 ANILCA report. Gammon and Chardler (1984) of Falconbridge Nickel Mines Ltd. subsequently described it as a large massive-sulfide deposit. One recent diamond drill hole intersected gold mineralization that averaged 0.3 ounces per ton over about 200 feet. This news encouraged considerable gold exploration in the area. St. Joe Minerals found a substantial gold prospect just east of the Windy-Craggy property in 1983, and this discovery has led to considerable claim staking in Alaska north of Haines (Petroleur Information, Alaska Report, Nov. 7, 1984).

At the Alaska Miners menting, Jones, Leveille, and Redman (1984) of Bear Creek Mining Company discussed their recent work on the old Jualin Mine in the Berners Bay district of southeastern Alaska. A significant tonnage is indicated, but Bear Creek has diverted their work elsewhere. However, Placid Oil Company is working on a similar deposit nearby (Petroleum Information, Alaska Report, Nov. 7, 1§\$4).

Barrick Resources Corporation has negotiated a 15-year lease with the city of Junenu and Alaska Electic Light and Power to examin? the AlaskaJuneau (A-J) and Treadwell mines near Juneau. Historically, the mines are the largest lode gold properties in Alaska, producing more than 7 million ounces of gold from the early 1880 s to 1941 . The Treadwell mines were major producers until 1917, when much of the underground workings flooded with seawater. Shortly thereafter, the A-J mine began production as what proved to be one of the most efficient low-grade gold mines in the world. Over several decades it produced a profit from ore than ran less than $\mathbf{0 . 0 4}$ ounce of gold Far ton of rock mined. The A-J closed in 1941 when gold mining was ruled non-essential to the war effort, and it has not had significant production since. The A-J had proven ore reserves of 29 million ton grading 0.04 ounce of gold per ton when it shut down, and the 
Treadwell had reserves of 7 million tons grading 0.11 ounce of gold per ton. Barrick Resources is committed to spend at least $\$ 500,000$ per year for 9 years and $\$ 1$ million for the next 6 years to retain the lease. Barrick planned to review the extensive records from past mining and exploration before beginning drilling on the properties (Northern Miner, March 29, 1984).

Queenstake Resources carried out a \$3-million exploration program during the summer of 1984 on their Chichagof gold property in southeastern Alaska. The property was a major gold producer prior to World War II. At least 14 drill targets have been identified, three of which were examined in 1984. The company has also identified at least 40,000 ounces of gold in tailings that can be processed economically (Northern Miner, April 15, 1984). Early in 1985, Queenstake, a joint partner with Exploration Ventures Company, announced a plan to re-open the Chichagof mine after they identified substantial reserves in the relatively narrow, but high-grade veins (Anchorage Times, Feb. 22, 1985; Anchorage Daily News, Feb. 22, 1985).

Also in southeastern Alaska, Bear Creek Mining Company worked on Zarembo Island near St. Johns Harbor for the second year. The target is a base metal deposit with precious metal values (Alaska Journal of Commerce and Pacific Rim Reporter, July 2, 1984).

\section{PLACER MINING FOR PRECIOUS METALS}

Alaskan precious metal production was almost entirely from gold placers. Placer gold production in 1984 was about 175,000 ounces, which came from more than 250 mines in every region of the State. According to information furnished by the Alaska Division of Geological and Geophysical Surveys (Eakins and others, 1985) production by region as ranked in order of decreasing importance was: (1) the eastern interior part of Alaska, with production of about 70,400 ounces of gold from 140 mines; (2) south-central Alaska, with about 37,500 ounces from 35 mines; (3) western Alaska, with about 36,000 ounces from 30 mines; (4) northern Alaska, with about 15,000 ounces from 20 mines; and (6) southeastern Alaska, with about 100 ounces from 2 mines.

A nagging problem confronting placer miners in 1984 was the steady decrease in gold prices to about $\$ 308$ per ounce at the end of 1984; it drifted even lower, below $\$ 300$, in the first quarter of 1985. However, as was brought out in numerous articles in the press and at various meetings, the most acute and contentious issue was water quality.

Placer mining is increasingly being subjected to Federal and State water-quality regulations, and much debate is taking place about the economic consequences of these regulations, the degree to which they should be enforced, and the level to which the various elements and materials that are remobilized during mining should and can be controlled. The basis for the enforcement of waterquality standards on Alaska streams on which placer mining occurs is the Federal Clean Water Act of 1971. Almost all Alaska's streams now fall under the highest classification of natural water defined in the Act-that is, the streams are useable for drinking, fishing, or swimming. Under the Act, such streams and rivers cannot be subjected to industrial activity that would reduce their water q'vality to below the standards for drinking, fishing, or swimming (Anchorage Times, March 4, 1984). In March, the EPA announced that Alaskan placer miners would have to comply with a stringent series of water-quality standards in 1984 or fa?e court action. Under the EPA's regulations, placer miners who move less than 20 cubic yards of gravel a day are exempt from the regulations. Mirors who handle up to 1,400 cubic yards of gravel are considered to be small miners and are required at the least to build settling ponds; larger operations would have to install pumps to recycle at least 97 percent of the water used in mining. Additional regulations require that the miners meet State water-quality standards for mercury and arsenic and for turbidity of the water downstream of placer operations. The EPA plan calls for permitting mining to cortinue for 2 years using only settling ponds, with mandatory water recyling at the end of that period. Environmental groups have criticized the proposed regulations as being too lenient, and mirors have objected to them as too complex and expensive and indicate the regulations would result in the loss of much fine gold (Anchorage Daily News, March 4 and 14, 1984; Petroleum Information, Alaska Report, March 11, 1984). In February 1985, the EPA proposed stiff, new turbidity standards for water discharged from placer mines. Strong opposition was expected from placer miners at public hearings schetuled for March. A spokesman for the Alaske Miners Association indicated that few placer minsrs could survive rigid enforcement of these $s^{t}$ andards. However, the EPA and a spokesman fmom one environmental group suggested that the issue is not one of rigid enforcement but rathe: of a conscientious effort by placer miners to work toward cleaner mining using modern terhnology (Anchorage Daily News, Feb. 14, 1985).

In late 1984, a Federal Circuit Col-t found that the EPA had failed to set adequate standards for arsenic and mercury in 170 place mining permits issued in 1976 and 1977. The court. ordered that the EPA review the standards and establish appropriate standards. In their appeal of thic action, the permit holders and the Alaska Miner: Association also indicated that the EPA had established overly stringent standards for suspended sand and clay particles in water below mining operations (Anchorage Daily News, Dec. 12, 1984).

At the 1984 Alaskan Mining Association Convention, a panel composed of membses from 
industry and government suggested that placer miners might work toward reclassification of streams and rivers on which placer mines exist to a lower classification-that is, classify them as suitable for fishing and swimming but not for drinking water. Such reclassification would make it easier to meet water-quality standards (Fairbanks Daily News Miner, Nov. 2, 1984).

In May 1984, the State of Alaska announced that it would waive its right of review over Federal placer mining permits in 1984 while working toward a comprehensive State policy on placer mining and establishing an enforcement mechanism for it. At the same time, the State set forth preliminary guidelines to establish which violations are serious enough to warrant court action. These stipulations are in the Interagency Placer Mining Guidelines that were worked out by the Department of Natural Resources, the Department of Environmental Conservation, and the Department of Fish and Game. Issues considered in these guidelines include (1) development of new technology to more efficiently mine gold and reduce pollution, (2) development of standards for settling ponds and recycling, reclassification of streams, and turbidity standards, (3) basin planning, and (4) enforcement policy. Work continues by these agencies to develop an improved State strategy to work with placer mining (Alaska Journal of Commerce and Pacific Rim Reporter, Oct. 19, 1984).

In August of 1984, however, in what may turn out to be an important test case, a State judge in Fairbanks refused a temporary restraining order originated by the Alaska Department of Environmental Conservation to enforce pollution control regulations against a miner whose operation is north of Fairbanks. This was the State's first attempt to enforce such regulations, and the judge ruled that they were deficient in not establishing clear and unequivocal guidelines for the miners (Fairbanks Daily News Miner, Sept. 28, 1984).

The following information about placer mining in Alaska describes only the major new developments in 1984 reported in the press or professional publications. Many of the significant developments over the past several years have been described in earlier reports in this series and are not reported here. Further, this circular does not include a comprehensive listing of placer operations in the State. The Division of Geological and Geophysical Surveys periodically publishes a list of Alaskan mining companies, including placer mines. (See Alaska Divison of Geological and Geophysical Surveys, 1985, and Eakins and others, 1985.) Locations of the operations mentioned below are shown in figure 8 .

Alaska Gold Company operated two dredges at Nome: Dredge No. 5 on Anvil Creek, and Dredge No. 6 west of the airport near the coast. Alaska Gold began dredging in Nome in 1974 as the corporate successor to the Nome operations of
Hammond Consolidated Gold Field: and United States Smelting, Refining, and Mining Company. These companies had operated gold dredges at Nome from 1923 to 1942 and from 1946 to 1962 . In 1983 , the two dredges produced 15,700 ounces of gold and employed 110 workers at Nome. Deep permafrost is present in the Nome area, and dredging requires expensive thawing operations several years prior to actual mining. As with several other Alaskan placer gold mines, Alaska Gold was severely impacted by the low price of gold in 1984, but the company indicated that more than 1 million ounces of proven gold remairs to be mined from ground that has been tested by prospect pits and drilling (Alaska Journal of Commerce and Pacific Rim Reporter, Sept. 24, 1984.)

Aspen Development Corporation continued exploration for submarine gold placers on 300,000 acres of offshore lands in Cook Inlet. held under a State permit. Work during the summer of 1984 included a marine geophysical survey, microseismic tests, and a sidescan sonar survey of the sea bottom (Alaska Construction and Oil, July 1984). In September, Aspen announced that their primary area of interest is from Anchor Point to Ninilchik on the east side of the Inlet and indicated that the area is amenable to dredging. Almost immediately after Aspen's announcement, sport ard commercial fisherman who fish in the proposed dredging area registered strong opposition (Anchrrage Times, June 25, 1984). (The Kenai Peninsula is an extremely productive sport fishery, and Cook Inlet supports a major commercial fishery.) Subsequently, the Kenai Peninsula Boro'igh Assembly formally asked the State to delay approval of Aspen's dredging plan for one year in order for the Borough to complete their Coastal Management Plan. In early 1985, State officials denied a permit required to continue work, on the grcinds that the program does not require either the State or the applicant to acquire biological or genlogical data sufficient to determine effects of the mining before permit issuance. The State plans to review the program (Anchorage Daily News, Feb. 9, 1984).

In another offshore project, Power Resources, Inc., signed an option agreement with Asarco, Inc., for 21,750 acres of submarine lands sisuth of Nome in the Bering Sea. Asarco obtained the property from Shell Oil Company, which began exploration for submarine gold placers off Norre more than 10 years ago. Power Resources indiceted they will begin work in 1985 on an 11-acre area of the leases, but the company does not anticiprte full-scale operations until at least 1986. Initial plans are for use of an offshore bucketwheel cutterhead dredge over a total area about 12 miles long and 2.5 miles wide. In late 1984, several local grc ups in Nome asked for hearings on this proposed mining to determine its potential effect on marine life (Anchorage Daily News, Dec. 27, 1984). At a hearing on January 23, 1985, an Frkimo group 
opposed mining until the company could guarantee no adverse impact on local marine food resources (Petroleum Information, Alaska Report, Jan. 30, 1985).

The Valdez Creek mine, operated by five companies (Camindex Mines; Barrick Resources; Talcorp Ltd.; Watts, Griffis and McOuat; and Sullivan Mines), was the largest gold producer in the State. The partners produced about 20,000 ounces of gold from the property in 1984 (Bressler, 1984). In the Brooks Range, the placer mine near Chandalar owned by Little squaw Gold Mining Company doubled its production in 1983 to 2,129 ounces, and the operators had hoped to double it again in the summer of 1984 (Anchorage Daily News, Feb. 2, 1984).

A new placer gold operation is planned on Crow Creek near Anchorage. The property was mined in the early part of the century but has long been dormant. About 200 acres of private land are involved, and most, if not all the various State and Federal permits are in hand. The Bureau of Mines recently estimated that the creek has produced about 42,500 ounces of gold since 1897 (Jansons and others, 1984).

The dredging operations proposed by Northland Gold Dredging Company on the Tuluksak River in southwestern Alaska were the subject of much debate through 1984. Northland planned a 6,750-foot diversion channel on the river to facilitate dredging. The people of the village of Tuluksak 30 miles downstream voiced strong objection to this diversion channel and any future dredging as a threat to their subsistence lifestyle by its effect on the salmon run on the river, the game population in the area, and possible metal contamination of the river (Anchorage Times, Feb. 24, 1984). In May 1984, the State of Alaska granted Northland a permit to go ahead with the diversion channel. The village of Tuluksak threatened further legal action. The issue stood unresolved at the end of 1984, and Northland was unable to do any dredging in 1984 due to the late date at which approval was granted by the State (Anchorage Daily News, May 12, 1984).

\section{IIJDUSTRIAL MINERALS}

With Alaska's booming construction industry, mining of sand and gravel continues to be a major, if somewhat unappreciated and low-key component of the Alaskan mining scene. About half of the total value of Alaska's mineral production came from sand and gravel (table 3). While sand and gravel resources are widespread, construction demands can increase the local price and require expensive import from other areas. Most of the sand and gravel consumption occurs in the Anchorage area (fig. 5), where more than half the State's population is concentrated. Several large operations have begun to work pits in the
Mantanuska Valley area northeast of Anchorage to avoid the increasing competition for land in the city and zoning regulations. However, in doing so, these operations are increasingly dependent on rail haulage via the Alaska Railroad into An?horage. According to an article in the Anchorag? Times (Feb. 24, 1985), gravel can be mined in the Matanuska Valley for between $\$ 1.50$ and $\$ 2$ a ton, but its price is $\$ 4.80$ after being brought by train to Anchorage. The railroad took in $\$ 9.4$ mi lion for hauling gravel in 1984 , about 8 carloads per day. In addition, the State sells about $\$ 2$ million worth of sand and gravel annually to North Slope oil companies, primarily for roads and work pads. Demand for sand and gravel on the Slope was significantly less in 1984 than in 1983, but construction there still accounted for almost half of the sand and gravel used statewide.

A proposal for a gravel mine on the southern Kenai Peninsula to supply the material to the city of Homer has resulted in a controversy. Cook Inlet Region, Inc., has proposed to mine gravel it owns in Kachemak Bay State Park and barge it to Homer. The Native corporation suggests the miring will have little effect on the park, but the Alaska Division of Parks opposes the proposed mine on environmental grounds. The issue is being resolved by the governor's Office of Management and Budget (Anchorage Daily News, May 23, 1984). Th? Homer area is highlighted in figure 8.

Doyon, Ltd., the Fairbanks-based Native corporation, continues to work toward production from their large asbestos deposit near Esgle (fig. 8). Doyon and its partners, GCO Mine-als and WGM, Ine., believe that the deposit is so rich and large that it must eventually be mined. However, the market for asbestos is extremely poor at present, due both to the general depressicn in the mining industry and the increasing concern with the environmental consequences of asbestos use. A spokesman from Doyon has indicated that the property probably would not be economically viable until the 1990s and then would require an investment of about $\$ 190$ million (Anchorage Times, March 15, 1984; Anchorage Daily News, March 16, 1984).

The discovery of two diamonds in a gold placer near Central (fig. 8) was one of the most exciting gem finds in Alaska in recent ysars. A diamond about a millimeter in diameter and onethird of a carat in weight was confirmed in 1984 (Anchorage Daily News, Dec. 13, 1984). Its rounded shape suggested it probably traveled a considerable distance from its source. A second, larger diamond was discovered in 1984. Typically, diamon ts occur in small bodies of a rock type termed kimberlite. Such rocks are not now known in the Central area but may occur. Conventional geologic theory suggests that a major diamond-bearing pipe is highly unlikely in central Alaska. 


\section{REFERENCES CITED}

Alaska Construction and Oil, P.O. Box 101980, Anchorage, AK 99510.

Alaska Division of Geological and Geophysical Surveys, 1985, Alaskan companies and prospectors-1983: Information Circular 7, 45 p. [1985 revised edition]

Alaska Economic Report, published by Alaska Information Service, 3037 South Circle, Anchorage, AK 99507.

Alaska Journal of Commerce and Pacific Rim Reporter, 715 L Street, Anchorage, AK 99501.

Alaska Land Use Council, 1984, Kantishna Hills/Dunkle Mine study report: 18 p., 18 appendices.

Alaska Miner, 509 West 3rd Ave., Suite 17, Anchorage, AK 99501

Anchorage Daily News, 200 Potter Drive, Anchorage, AK 99502.

Anchorage Times, 840 West 4 th Avenue, Anchorage, AK 99501.

Barnwell, W. W., and Pearson, K. S., 1984, Alaska's resource inventory 1984: Alaska Division of Geological and Geophysical Surveys Special Report 36, 62 p.

Berg, H. C., 1984, Regional geologic summary, metallogenesis, and mineral resourcs of southeastern Alaska: U.S. Geological Survey Open-File Report 84-572, 298 p.

Bressler, J. R., 1984, Geology of a buried channel system at the Denali placer gold mine (abs.): Ninth Annual Convention, Anchorage, Alaska Oct. 31-Nov. 3, 1984, Alaska Miners Association, Abstracts, p. 1.

Bundtzen, T. K., and others, 1984, Alaska's mineral industry, 1983: Alaska Div. of Geological and Geophysical Surveys Special Report 33, 56 p.

Business Week, 1221 Avenue of the Americas, New York, NY 10020.

Cobb, E. H., (comp.), 1984a, Map showing occurrence of placer gold in Alaska: U.S. Geological Survey Mineral Investigations Resource Map MR-83, 18 p. 1 sheet, scale $1: 2,500,000$.

Cobb, E. H., (comp.), 1984b, Map showing occurrence of lode gold and silver in Alaska: U.S. Geological Survey Mineral Investigations Resource Map MR-84, 16 p., 1 sheet, scale $1: 2,500,000$.

Cobb, E. H., (comp.), 1984c, Map showing occurrence of tungsten minerals in Alaska: U.S. Geological Survey Mineral Investigations Resource Map MR-85, 6 p., 1 sheet, scale $1: 2,500,000$.

Cobb, E. H., (comp.), 1984d, Map showing occurrence of molybdenum minerals in Alaska: U.S. Geological Survey Mineral Investigations Resource Map MR-86, 5 p., 1 sheet, scale $1: 2,500,000$.

DOWL Engineers/PLANgraphics, Inc., 1984, Mining properties acquisition costs-Kantishna Hills and Dunkle Mine Study Area, D?nali National Park, Alaska: Bureau of Mines Open File Report 128-84, 177 p.

Eakins, G. R., Bundtzen, T. K., Lueck, L. L., Green, C. B., Gallager, J. A., and Co'eman, D. A., 1985, Alaska's mineral industry 1985: Alaska Division of Geological and Geoprvsical Surveys Special Report 38, 57 p.

Environmental Protection Agency and Department of the Interior, 1984, Final Environmental Impact Statement, Red Dog Mine Project, northwest Alaska: V. I (text) and V. II (appendices), not consecutively proinated.

Fairbanks Daily News Miner, Box 710, Fairbanks, AK 99707.

Gammon, J. B., and Chandler, T. E., 1984, WindyCraggy massive sulfide deposit, northwestern British Columbia: Abstract presented at the Ninth Annual Convention, Alaska Miners Association, Anchorage, Alaska, Oct. 31-Nov. 3,1984 .

Hawley, C. C., and Reed, John, 1984, Breccia pipe and associated mineral deposits at Golden Zone mine: Abstract presented at the Ninth Annual Convention, Alaska Miners Association, Anchorage, Alaska, Oct. 31- Nov. 3, 1984.

Hoekzema, R. B., 1984, Strategic and critical mineral development potential of the Chugach National Forest, southeentral Alaska: Bureau of Mines Open File Report 215-84, 64 p., 1 sheet, scale $1: 250,000$.

Jansons, Uldis, Hoekzema, R. B., Kurtak, J. M., and Fechner, S. A., 1984, Mineral occurrences in the Chugach National Forest, southeentral Alaska: Bureau of Mines Mineral Lands Assessment 5-84, 43 p., appendix, 2 map sheets.

Jeske, R. E., 1984, Regional distribution of critical and strategic minerals in the Kantishna Hills area, Denali National Park and Preserve, Alaska: U.S. Bureau of Mines Open-file Report 214-84, 97 p., 4 sheets, scale 1:63,360.

Jones, B. K., Leveille, R. A., and Redman, Earl, 1984, Geology and mineralization of the Jualin gold mine: Abstract presented at the Ninth Annual Convention, Alaska Miners Association, Anchorage, Alaska. Oct. 31-Nov. 3, 1984.

Marsh, S. P., Kropschot, S. J., and Dickinson, R. G., 1984, Wilderness mineral potential-Assessment of mineral resource potential in U.S. Forest Service lands studied 1964-1984: U.S. Geological Survey Professional Froer 1300, v. $1,550 \mathrm{p}$.

Meyer, M. P., 1985, Mineral investization of the Iditarod-George Planning Blcre, central Kuskokwim area: U.S. Bureau of Mines Open File Report 9-85, 232 p., 4 sheets, scale $1: 250,000$.

National Park Service, 1984, Final Fnvironmental Impact Statement for the Kantishna Hills/Dunkle Mine Study Report: 616 p. 
Nelson, S. W., Miller, M. L., Barnes, D. F., Dumoulin, J. A., Goldfarb, R. J., Koski, R. A., Mull, C. G., Pickthorn, W. J. Jansons, Uldis, Hoekzema, R. B., Kurtak, J. M., and Fechner, S. A., 1984, Mineral potential resource map of the Chugach National Forest, Alaska: U.S. Geological Survey Miscellaneous Field Studies Map MF-1645A, 24 p., 1 sheet, scale 1:250,000.

Newberry, Rainer, 1984, Overview of gold skarns, southern and southeast Alaska: Abstract presented at the Ninth Annual Conventions, Alaska Miners Association, Oct. 31-Nov. 3, 1984.

Northern Miner, 7 Labatt Ave., Toronto, Canada, M5A 3 P2

Patton, W. W., Jr., Moll, E. J., and King, H. D., 1984, The Alaska Mineral Resource Assessment Program-Guide to information contained in the folio of geologic and mineral-resource maps of the Medfra quadrangle, Alaska: U.S. Geological Survey Circular 928, 11 p.

Petroleum Information, Alaska Report, published by Petroleum Information, a subsidiary of A. C. Nielson, P.O. Box 102278, Anchorage, AK 99510.

Salisbury and Dietz, Inc., 1983 [1984], 1983 Mineral resource studies, Kantishna Hills and Duakle Mine areas, Denali National Park and Preserve, Alaska: Bureau of Mines Open File Report 12984,2 v., 1,080 p.

Sims, J. F. M., and Green, C. B., 1985, Future of Alaskan mining discussed: Mining Engineering, v. 37 , no. 1, p. $15-18$.

Still, J. C., 1984a, Stratiform massive sulfide deposits in the Mt. Henry Clay area, southeast Alaska: Bureau of Mines Open File Report 118$84,65 \mathrm{p}$.

Still, J. C., 1984b, Stream sediment, float, and bedrock samples in the Porcupine mining area, southwest Alaska: Bureau of Mines Open File Report 173-84, 6 p.

U.S. Geological Survey and U.S. Bureau of Mines, 1984, Mineral resources of the Tracy ArmFords Terror Wilderness Study Area and vicinity, Alaska: U.S. Geological Survey Bulletin 1525, 308 p.

Western Miner, 1202 Melville St., Vancouver, B.C., Canada V6E $2 \times 9$.

West, R. L., and Deschu, N. A., 1984, Kantishna Hills heavy metals investigations, Denali National Park, 1983: Report prepared under Interagency Agreement No. 14-16-007-82-5524 between the National Park Service and the U.S. Fish and Wildlife Service, Anchorage, 42 p.

\section{SELECTED REFERENCES}

The following lists of references contain titles of books and articles about energy and mineral resources in Alaska that were published in 1984 or early 1985. This is not a complete listing of the publications of any agency, and it does not include articles about hydrology, seismicity, paleontoloy, or offshore geology, even though some information about these topics may have been used to pmepare the listed reports.

The U.S. Geological Survey regularly puhlishes its findings in several types of reports. A $\mathrm{m}$ onthly listing titled "New Publications of the U.S. Geological Survey" is available free from the Geological Survey, 582 National Center, Reston, VA 22092. The contents of these lists are compiled into an annual booklet, "Publications of the Geological Survey, [year]". Prices and addresses of the offices from which the reports can be obtained are given in the monthly listings. This information is also available at the Survey's Public mquiries Offices.

The Bureau of Mines also publishes a variety of reports about its work. The Bureau of Mines' central distribution office is the Brarmh of Production and Distribution, 4800 Forbes Ave., Pittsburgh, PA 15213. Many Bureau reports are available from the U.S. Government Printing office in Washington, D.C., and some are available through the National Technical Information Service in Springfield, Va. The Bureau's reports listed hare are available at the Bureau of Mines Juneau library; for more information, contact the Chief, Alaska Field Operations Center, 201 East 9th Ave., Anchorage, AK 99501.

Reports by other Federal and State anoies are generally available from the agencies' Alaska offices or are in the Department of the Interior's Alaska Resources Library in the Federal B-ilding, 701 C Street, Anchorage, AK 99513.

\section{U.S. GEOLOGICAL SURVEY}

\section{Professional Papers}

Marsh, S. P., Kropschot, S. J., and Dickinsor. R. G., 1984, Wilderness mineral potential-Assessment of mineral resouree potential in U.S. Forest Service lands studied 1994-1984: U.S. Geological Survey Professional Paper 1300, v. 1,550 p. [Pages 29-46 contain articles about Alaskan areas.]

U.S. Geological Survey, 1984, Geological Survey research, fiscal year 1981: U.S. Gełogical Survey Professional Paper 1375, 424 p.

\section{Bulletins}

Barnes, D. F., 1984, Interpretation of 8 vailable gravity data, in Mineral Resources of tl $:$ Traey Arm-Fords Terror Wilderness Study Area and vicinity, Alaska: U.S. Geologieal Survey Bulletin 1525, Part C, p. 63-72.

Brew, D. A., and Grybeck, Donald, 1984, Geoloy of the Tracy Arm-Fords Terror Wilderness Study Area and vicinity, Alaska, in Mineral Resources of the Tracy Arm-Fords Terror Wilderness Area and vicinity, Alaskr: U.S. Geological Survey Bulletin 1525, Part A, p. 1952. 
Grybeck, Donald, Johnson, B. R., and Nutt, C. J., 1984, Geochemistry of the Tracy Arm-Fords Terror Wilderness Study Area and vicinity, in Mineral Resource of the Tracy Arm-Fords Terror Wilderness Study Area and vicinity, Alaska: U.S. Geological Survey Bulletin 1525, Part D, p. 73-104.

Hein, J. R., Mclean, Hugh, and Vallier, T. L., 1984, Reconnaissance geology of southern Atka Island, Alaska: U.S. Geological Survey Bulletin $1609,19 \mathrm{p}$.

Jachens, R. C., 1984, Interpretation of the aeromagnetic data, in Mineral Resources of the Tracy Arm-Fords Terror Wilderness Study Area and vicinity, Alaska: U.S. Geological Survey Bulletin 1525, Part B, p. 53-62.

Kimball, A. L., Still, J. C., and Rataj, J. L., 1984, Mineral deposits and occurrences in the Tracy Arm-Fords Terror Wilderness Study Area and vicinity, in Mineral Resources of the Tracy Arm-Fords Terror Wilderness Study Area and vicinity, Alaska: U.S. Geological Survey Bulletin 1525, Part E, p. 105-210.

\section{Circulars}

Barnes, D. F., and Morin, R. L., 1984, Gravity measurements show large size of Red Dog zinclead-barite prospect in northwestern Alaska, in Reed, K. M., and Bartsch-Winkler, Susan, eds., The United States Geological Survey in AlaskaAccomplishments during 1982: U.S. Geological Survey Circular 939, p. 1-5.

Case, J. E., 1985, Some geophysical guides to ore on southern and southwestern Alaska (abs.), in Krafft, Kathleen, ed., USGS research on mineral resources-1985 program and abstracts: U.S. Geological Survey Circular 949, p. 5-7.

Curtin, G. C., Tripp, R. B., O'Leary, R. M., and Huston, D. L., 1984, Geochemically anomalous areas north of the Denali fault in the Mount Hayes quadrangle, southern Alaska, in Coonrad, W. L., and Elliott, R. L., The United States Geological Survey in Alaska-Accomplishments during 1981: U.S. Geological Survey Circular 868, p. 48-50.

Coonrad, W. L., and Elliott, R. L., eds., 1984, The United States Geological Survey in AlaskaAccomplishments during 1981: U.S. Geological Survey Circular 868, 162 p.

Davis, R. E., 1985, Organization, programs, and activities of the Geologic Division, U.S. Geological Survey: U.S. Geological Survey Circular 1000, 26 p.

Ellersieck, Inyo, Blanchard, D. C., Curtis, S. M., Mayfield, C. F., and Tailleur, I. L., 1984, Kivivik Creek-A possible lead-zinc-silver occurrence in the Kuna Formation, western Baird Mountains, in Coonrad, W. L., and Elliott, R. L., eds., The United States Geological Survey in Alaska-Accomplishments during
1981: U.S. Geological Survey Circular 868, p. 16-17.

Evenson, E. B., Stephens, G. C., Neh?r, F. R., King, H. D., and Detra, D. E., 1984, Mineral exploration and reconnaissance betrock mapping using active alpine glaciers, Mount Hayes and Healy quadrangles, southern Alaska, in Coonrad, W. L., and Elliott, R. L., eds., The United States Geological Surv ry in AlaskaAccomplishments during 1981: U.S. Geological Survey Circular 868, p. 94-95.

Filipek, L. H., 1984, The possible significance of diagenetic remobilization of ore elements in the mud-flat estuarine environment, in Reed, K. M., and Bartsch-Winkler, Susan, eds., The United States Geological Survay in AlaskaAccomplishments during 1982: U.S. Geological Survey Circular 939, p. 96-100.

Goldfarb, R. J., 1984, A preliminary geochemical interpretation of the Chugach Wilderness, southern Alaska, in Coonrad, W. L., and Elliott, R. L., eds., The United States Geological Survey in Alaska-Accomplishments during 1981: U.S. Geological Survey Circular 868, p. 89-92.

Goldfarb, R. J., Folger, P. F., Smaglik, S. M., and Tripp, R. B., 1984, A statistical interpretation of geochemical data from Chi'rach National Forest, in Reed, K. M., and Bartsch-Winkler, Susan, eds., The United States Geological Survey in Alaska-Accomplistments during 1982: U.S. Geological Survey C:rcular 939, p. 47-50.

Grybeck, D. J., and Nelson, S. W., 1985, Mineral resources of the Survey Pars quadrangle, Brooks Range, Alaska (abs.), in Krafft, Kathleen, ed., USGS research on mineral resources-1985 program and abstracts: U.S. Geological Survey Circular 949, r 17-19.

Keith, T. E. C., 1984, Preliminary cbservations on fumarole distribution and alteration, Valley of 10,000 Smokes, Alaska, in Reet, K. M., and Bartsch-Winkler, Susan, eds., The United States Geological Survey in Alaska-Ac :omplishments during 1982: U.S. Geological S rrvey Circular 939, p. 82-85.

King, H. D., 1984, Geochemical survey of the Solomon and Bendeleben quadrengles, Seward Peninsula, Alaska, in Reed, K. M., and BartschWinkler, Susan, eds., The Inited States Geological Survey in Alaksa-Ac:omplishments during 1982: U.S. Geological Sirvey Circular 939, p. 33-37.

Krafft, Kathleen, ed., 1985, USGS research on mineral resources-1985 progrnms and abstracts: U.S. Geological Survey Circular 949, $72 \mathrm{p}$.

Nelson, S. W., 1985, A multidisciplinary resource assessment of the Chugach National Forest, Alaska (abs.), in Krafft, Kathleen, ed., USGS research on mineral resources-1985 program 
and abstracts: U.S. Geological Survey Circular 949, p. 34-36.

Nokleberg, W. J., and Lange, I. M., 1985, Metallogenic history of the Wrangellia terrane, eastern Alaska Range, Alaska (abs.), in Krafft, Kathleen, ed., USGS research on mineral resources-1985 program and abstracts: U.S. Geological Survey Circular 949, p. 36-38.

Nokleberg, W. J., Lange, I. M., and Roback, R. C., 1984, Preliminary accretionary terrane model for metallogenesis of the Wrangellia terrane, southern Mount Hayes quadrangle, eastern Alaska Range, Alaska, in Reed, K. M., and Bartsch-Winkler, Susan, eds., The United States Geological Survey in Alaska-Accomplishments during 1982: U.S. Geological Survey Circular 939, p. 60-65.

Patton, W. W., Jr., Moll, E. J., and King, H. D., 1984, The Alaska Mineral Resources Assessment Program-Guide to information contained in the folio of geologic and mineral-resource maps of the Medfra quadrangle, Alaska: U.S. Geological Survey Circular 928, 11 p.

Pickthorn, W. J., and Silberman, M. L., 1984, Structural relations and fluid-inclusion data for mineralized and nonmineralized quartz veins in the Port Valdez gold district, Valdez quadrangle, southern Alaska, in Coonrad, W. L., and Elliott, R. L., eds., The United States Geological Survey in Alaska-Accomplishments during 1981: U.S. Geological Survey Circular 868 , p. 86-89.

Silberman, M. L., and Madden, D. J., 1985, Characteristics of lode-gold deposits in the Prince William Sound region, southern Alaska (abs.), in Krafft, Kathleen, ed., USGS research on mineral resources-1985 program and abstracts: U.S. Geological Survey Circular 949, p. 49-51.

Silberman, M. L., O'Leary, R. M., Gray, Leda Beth, and Patton, W. W., Jr., 1984, Trace-metal anomalies associated with silicification and argillic alteration in a rhyolite flow-dome complex in volcanic rocks of the Nowitna River area, Medfra quadrangle, Alaska, in Coonrad, W. L., and Elliott, R. L., eds., The United States Geological Survey in Alaska-Accomplishments during 1981: U.S. Geological Survey Circular 868, p. 32-34.

Reed, K. M., and Bartsch-Winkler, Susan, eds., 1984, The United States Geological Survey in Alaska-Accomplishments during 1982: U.S. Geological Survey Circular 939, 165 p.

U.S. Geological Survey, 1984, 1984 Annual report on Alaska's mineral resources: U.S. Geological Survey Circular 940, $54 \mathrm{p}$.

Wilson, F. H., and York, J. E., 1985, Processing of Landsat imagery to map surface mineral alteration on the Alaska Peninsula, Alaska (abs.), in Krafft, Kathleen, ed., USGS research on min- eral resources-1985 program and abstracts: U.S. Geological Survey Circular 949, p. 56-57.

Winkler, G. R., 1985, The Alaska Mineral Resource Assessment Program (abs.), in Krafft, Kathleen, ed., USGS research on mineral resources-1985 program and abstracts: U.S. Geological Survey Circular 949, p. 66-68

Yeend, W. E., 1984, Placers and placer mining in the Healy quadrangle, southern Alaska, in Coonrad, W. L., and Elliott, R. L., eds., The United States Geological Survey in AlaskaAccomplishments during 1981: U.S. Genlogical Survey Circular 868, p. 95-98.

Yeend, W. E., 1984, Gold in Tertiary(?) rocks, Circle quadrangle, in Coonrad, W. L., and Elliott, R. L., eds., The United States Geological Survey in Alaska-Accomplishments during 1981: U.S. Geological Survey Circular 868, p. 65-66.

\section{Open-File Reports}

Bader, J. W., 1984, Geologic map of the Demarcation Point, Mt. Michelson, Flaxman Island, and Barter Island quadrangles, Alaska: U.S. Geological Survey Open-File Report 84-596, 1 sheet, scale 1:250,000.

Berg, H. C., 1984, Regional geologic summary, metallogenesis, and mineral resour?es of southeastern Alaska: U.S. Geological Survey Open-File Report 84-572, 298 p.

Bird, K. J., 1984, A comparison of the play-2nalysis technique as applied in hydrocarbon $r$ source assessments of the National Petroleum Reserve in Alaska and of the Arctic National Wildlife Refuge: U.S. Geological Survey Oron-File Report 84-78, 21 p.

Brosgé, W. P., and Tailleur, I. L., 1984, Irorganic chemical analyses of black shale from wells in the National Petroleum Reserve in Alaska: U.S. Geological Survey Open-File Report 84641,25 p.

Brew, D. A., Ovenshine, A. T., Karl, S. M., and Hunt, S. J., 1984, Preliminary reconne.issance geologic map of the Petersburg and part of the Port Alexander and Sumdum 1:250,00? quadrangles, southeastern Alaska: U.S. Geslogical Survey Open-File Report 84-405, 43 p., 2 oversize sheets, scale 1:250,000.

Bruns, T. R., 1985, Tectonics of the Yakutat block, an allochthonous terrane in the northern Gulf of Alaska: U.S. Geological Survey Open-File Report 85-13, 112 p.

Burrell, P. D., 1984, Map and table descrit'ng the Admiralty-Revillagigedo instrusive belt plutons in the Petersburg 1:250,000 quadrangle, southeastern Alaska: U.S. Geological Survey OpenFile Report 84-171, 6 p., 1 map: scale $1: 250,000$.

Detterman, R. L., 1984, Measured sections of late Paleozoic and Mesozoic rocks, Mount Michelson 
quadrangle, Alaska: U.S. Geological Survey Open-File Report 84-331, 2 sheets.

Detterman, R. L., 1984, Measured sections of upper Paleozoic to early Tertiary rocks, Demarcation Point quadrangle, Alaska: U.S. Geological Survey Open-File Report 84-370, 1 sheet.

Di Bona, P. A., and Kirschner, C. E., 1984, Geologic bibliography for selected onshore sedimentary basins of central and southern Alaska stressing basin analysis and including an index of publicly available well and subsurface data: U.S. Geological Survey Open-File Report 84-99, 70 p.

Donovan, T. J., 1984, Preliminary airworthiness and operational evaluation of an ultralight aircraft as a geological reconnaissance vehicle: U.S Geological Survey Open-File Report 84-286, $15 \mathrm{p}$.

Douglass, S. L., and Cobb, E. H., 1984, Geological bibliography of the Juneau project area, Alaska: U.S. Geological Survey Open-File Report 84-564, 33 p.

Foster, H. L., O'Leary, R. M., MeDougal, C. M., and Menzie, W. D., 1984, Analyses of rock samples from the Circle quadrangle, Alaska: U.S. Geological Survey Open-File Report 84479,126 p., 1 pl., scale 1:1,250,000.

Galloway, J. P., Bibliography of published radiocarbon dates for Alaska: U.S. Geological Survey Open-File Report 84-21, $44 \mathrm{p}$.

Gehrels, G. E., and Berg, H. C., 1984, Geologic map of southeastern Alaska: U.S. Geological Survey Open-File Report 84-886, 28 p., scale $1: 600,000$.

Goldfarb, R. J., Nelson, S. W., Dumoulin, J. A., and Miller, M. L., 1984, Data report and statistical summary for samples of moraine and stream sediment, nonmagnetic heavy-mineral concentrate and rock from the Chugach National Forest, Alaska: U.S. Geological Survey OpenFile Report 84-355, 446 p. (incl. appendices), 2 oversize sheets, scale $1: 250,000$.

Goodfellow, Robert, Nelson, S. W., Bouse, R. M., and Koski, R. A., 1984, The geologic setting and composition of a newly discovered manganese deposit on Hinchinbrook Island: U.S. Geological Survey Open-File Report 84-671, 10 p.

Grybeck, D. J., Berg, H. C., and Karl, S. M., 1984, Map and description of the mineral deposits in the Petersburg and eastern Port Alexander quadrangles, southeastern Alaska: U.S. Geological Survey Open-File Report 84-837, 87 p., scale $1: 250,000$.

Hamilton, T. D., and Bauer, D. P., 1984, Engineering-geologic maps of northern AlaskaHoward Pass quadrangle: U.S. Geological Survey Open-File Report 84-401, 1 sheet, scale $1: 250,000$.

Hopkins, B. A., 1983 [1984], Geological maps on Alaska published by the U.S. Geological Survey, post-1930, scales $1: 96,000$ to $1: 250,000$ : U.S. Geological Survey Open-File Report 83-577, 20 p., 1 sheet.
Hopkins, B. A., 1983 [1984], Geologic maps on Alaska published by the U.S. Geo'ngical Survey, post-1930, scales 1:20,000 to 1:63,360: U.S. Geological Survey Open-File Feport 83-578, 18 p., 1 sheet.

Huffman, A. C., Jr., Ahlbrandt, T. S., Pasternak, Ira, Fox, J. E., Bartsch-Winkler, Susan, May, F. E., and Scott, R. A., 1984, Measured sections of the Cretaceous Nanushuk Group undivided, western North Slope, Alaska: U.S. Geological Survey Open-File Report 84-1i6, microfilm, with 84-177.

Huffman, A. C., Ahlbrandt, T. S., Fłsternak, Ira, Stricker, G. D., Bartsch-Winkler, Susan, Fox, J. E., May, F. E., and Scott, R. A., 1984, Measured sections of the Cretacious Nanushuk and Colville Groups undivided, central North Slope, Alaska: U.S. Geological Survey OpenFile Report 84-177, microfilm, with 84-176.

Johnson, B. R., and Elliott, G. S., 1984, Map showing bedrock geochemical station locations, Western Chichagof-Yakobi Islants Wilderness study area, southeastern Alaska: U.S. Geological Survey Open-File Report 81-27A, scale $1: 250,000$.

Johnson, B. R., and Elliott, G. S. 1984, Map showing the distribution and aburdance of gold and silver in bedrock samp'os, Western Chichagof-Yakobi Islands Wildorness study area, southeastern Alaska: U.S. Geological Survey Open-File Report 81-27B, 1 sheet, scale $1: 250,000$.

Johnson, B. R., and Elliott, G. S., 1984, Map showing the distribution and abundance of boron and beryllium in bedrock samples, Western Chichagof-Yakobi Islands Wilderness study area, southeastern Al $\varepsilon$ ska: U.S. Geological Survey Open-File Report 81-27C, 1 sheet, scale $1: 250,000$.

Johnson, B. R., and Elliott, G. S., 1984, Map showing the distribution and abundance of copper in bedrock samples, Weste'n ChichagofYakobi Islands Wilderness study area, southeastern Alaska: U.S. Geological Survey Open-File Report $81-27 \mathrm{D}, 1$ sheet, scale $1: 250,000$.

Johnson, B. R., and Elliott, G. S., 1984, Map showing the distribution and Ebundance of cobalt in bedrock samples, Western ChichagofYakobi Islands Wilderness study area, southeastern Alaska: U.S. Geolngical Survey Open-File Report 81-27E, 1 sheet, scale $1: 250,000$.

Johnson, B. R., and Elliott, G. S.. 1984, Map showing the distribution and abundance of molybdenum, tin, and vanadium in bedrock samples, Western Chichagof-Yokobi Islands Wilderness study area, southeastern Alaska: U.S. Geological Survey Open-File Report 8127F, 1 sheet, scale 1:250,000.

Johnson, B. R., and Elliott, G. S., 1984, Map showing the distribution and abundance of 
nickel and chromium in bedrock samples, Western Chichagof-Yakobi Islands Wilderness study area, southeastern Alaska: U.S. Geological Survey Open-File Report 81-27G, 1 sheet, scale $1: 250,000$.

Johnson, B. R., and Elliott, G. S., 1984, Map showing the distribution and abundance of lead in bedrock samples, Western Chichagof-Yakobi Islands Wilderness study area, southeastern Alaska: U.S. Geological Survey Open-File Report 81-27H, 1 sheet, scale 1:250,000.

Johnson, B. R., and Elliott, G. S., 1984, Map showing the distribution and abundance of scandium and yttrium in bedrock samples, Western Chichagof-Yakobi Islands Wilderness study area, southeastern Alaska: U.S. Geological Survey Open-File Report 81-27I, 1 sheet, scale 1:250,000.

Johnson, B. R., and Elliott, G. S., 1984, Map showing the distribution and abundance of strontium and lanthanum in bedrock samples, Western Chichagof-Yakobi Islands Wilderness study area, southeastern Alaska: U.S. Geological Survey Open-File Report 81-27J, 1 sheet, scale 1:250,000.

Johnson, B. R., and Elliott, G. S., 1984, Map showing the distribution and abundance of zinc in bedrock samples, Western Chichagof-Yakobi Islands Wilderness study area, southeastern Alaska: U.S. Geological Survey Open-File Report 81-27K, 1 sheet, scale 1:250,000.

Kachadoorian, Reuben, and Crory, F. E., 1984, Engineering geology studies in the National Petroleum Reserve, Alaska: U.S. Geological Survey Open-File Report 83-6, 37 p.

Kelley, J. S., 1984, Geologic sections of a portion of the Chandler Lake B-1 quadrangle, Alaska: U.S Geological Survey Open-File Report 84-77, 3 oversize sheets.

Kelley, J. S., 1984, Geologic map and sections of the southwestern Kenai Peninsula west of the Port Graham fault, Alaska: U.S. Geological Survey Open-File Report 84-152, 1 sheet, scale $1: 63,360$.

Kelley, J. S., 1984, Geologic map and sections of a portion of the Chandler Lake A-1 and A-2 quadrangles, Alaska: U.S. Geological Survey Open-File Report $84-555$, scale $1: 63,360$.

Mayfield, C. F., Ellersieck, Inyo, and Tailleur, I. L., 1984, Reconnaissance geologic map of the Noatak C5, D6, and D7 quadrangles, Alaska: U.S. Geological Survey Open-File Report 84396,1 sheet, scale 1:63,360.

Molenaar, C. M., Kirk, A. R., Magoon, L. B., and Huffman, A. C., 1984, Twenty-two measured sections of Cretaceous-Lower Tertiary rocks, eastern North Slope, Alaska: U.S. Geological Survey Open-File Report 84-695, 19 p., 4 sheets.

O'Leary, R. M., Hoffman, J. D., Sutley, S. J., and King, H. D., 1984, Analytical results and sample locality map of stream-sediment and heavy-mineral-concentrate samples from the Healy quadrangle, Alaska: U.S. Geological Survey Open-File Report 84-104, 153 p., 1 oversize map.

O'Leary, R. M., Hoffman, J. D., Sutley, S. J., and Lewis, S. J., 1984, Analytical results and sample locality maps of stream-sediment, heavy-mineral-concentrate, pebble and rock samples from the Wiseman quadringle, Alaska: U.S. Geological Survey Open-File Report 84-161, 400 p., 3 oversize sheets.

Parduhn, N. L. and Watterson, J. L., 1984, Preliminary studies of Bacillus coreus distribution near a gold vein and a disseminated gold deposit: U.S. Geological Survey Open-File Report 84-509, 8 p.

Roberts, W. S., 1984, Economic potential for chromium, platinum, and palladium in the $\mathrm{Mt}$. Hurst ultramafies, west-central area, Alaska: U.S. Geological Survey-Bureau of Mines OpenFile Report 84-22, 52 p.

Silberling, N. J., and Jones, D. L., Lithotectonic terrane maps of the North American Cordillera: U.S. Geological Survey Open-File F aport 84-523, Parts A-D, 4 map sheets, scale 1:2,500,000. Part A, Alaska; part B, western Canada and southeastern Alaska.

Sutley, S. J., Duttweiler, K. A., and Hopkins, R. T., Analytical results and sample locality maps of stream-sediment and panned concentrate samples from the Killik River $1^{\circ} \times 3^{\circ}$ quadrangle [Alaska]: U.S. Geological Sirvey Open-File Report 84-406, 18 p., 1 sheet, scale $1: 250,000$.

Sutley, S. J., Duttweiler, K. A., and Hopkins, R. T., 1984, Analytical results and sample locality maps of stream-sediment and p $\varepsilon$ nnedconcentrate samples from the Chandler Lake $1^{\circ}$ $x \quad 3^{\circ}$ quadrangle [Alaska]: U.S. Geoligical Survey Open-File Report 84-412, 30 p., 1 sheet, scale 1:250,000.

Tripp, R. B., and Cathrall, J. B., 1984, Mineral gical map showing the distribution of se'ected minerals in nonmagnetic fractions of ravymineral concentrates from stream sediments, Petersburg area, southeast Alaska: U.S. Geological Survey Open-File Report 83-420-X, 1 sheet, scale 1:250,000.

U.S. Geological Survey, 1984, Aeromagnetic rap of parts of the Ugashik and Karluk $1^{\circ} \times 2^{\circ}$ quadrangles, Alaska: U.S. Geological Survey Open-File Report 84-351, 2 sheets, scale $1: 250,000$.

U.S. Geological Survey, 1984, Aeromagnetic map of the western part of the Healy $1^{\circ} \times 3^{\circ}$ quadrangle, Alaska: U.S. Geological Survey Open-File Report 84-295, 1 sheet, scale $1: 250,000$.

U.S. Geological Survey, 1984, Aeromagnetic map of the Juneau area, Alaska: U.S. Geological 
Survey Open-File Report 84-296, 1 sheet, scale $1: 250,000$.

U.S. Geological Survey, 1984, Aeromagnetic map of the Killik River and Chandler Lake $1^{\circ} \times 2^{\circ}$ quadrangles, Alaska: U.S. Geological Survey Open-File Report 83-607, 1 sheet, scale $1: 250,000$.

U.S. Geological Survey, 1984, Aeromagnetic map of parts of the Ugashik and Karluk $1^{\circ} \times 2^{\circ}$ quadrangles Alaska: U.S. Geological Survey Open-File Report 84-351, 2 sheets, scale $1: 250,000$.

U.S. Geological Survey, 1984, Aeromagnetic map of part of the Anchorage $1^{\circ} \times 3^{\circ}$ quadrangle, Alaska: U.S. Geological Survey Open-File Report 84-352, 1 sheet, scale 1:250,000.

U.S. Geological Survey, 1984, Aeromagnetic map of the Craig area, Alaska: U.S. Geological Survey Open-File Report 84-666, 3 sheets, scale $1: 250,000$.

Watterson, J. R., Nishi, J. M., and Botinelly, Theodore, 1984, Evidence that gold crystals can nucleate on spores of Bacillus cereus: U.S. Geological Survey Open-File Report 84-487, 8 p.

Williams, J. R., and Carter, L. D., 1984, Engineering-geologic maps of northern Alaska, Barrow quadrangle: U.S. Geological Survey Open-File Report 84-124, 38 p., 2 plates, scale $1: 250,000$.

Yeend, Warren, 1984, Engineering-geologic maps of northern Alaska, Utukok River quadrangle: U.S. Geological Survey Open-File Report 84682,2 sheets, scale $1: 250,000$.

\section{Mineral Investigations Resource Maps}

Cobb, E. H., (comp.), 1984, Map showing occurrences of placer gold in Alaska: U.S. Geological Survey Mineral Investigations Resource Map MR-83, 18 p., 1 sheet, scale $1: 2,500,000$.

Cobb, E. H., (comp.), 1984, Map showing occurrences of lode gold and silver in Alaska: U.S. Geological Survey Mineral Investigations Resource Map MR-84, 16 p., 1 sheet, scale $1: 2,500,000$.

Cobb, E. H., (comp.), 1984, Map showing occurrences of tungsten minerals in Alaska: U.S. Geological Survey Mineral Investigations Resource Map MR-85, 6 p., 1 sheet, scale $1: 2,500,000$. [Supersedes Open-File Report 82785.]

Cobb, E. H., (comp.), 1984, Map showing occurrences of molybdenum minerals in Alaska: U.S. Geological Survey Mineral Investigations Resource Map MR-86, 5 p., 1 sheet, scale 1:2,500,000. [Supersedes Open File Report 82-798.]

Cobb, E. H., (comp.), 1984 [1985], Map showing occurrences of copper minerals in Alaska: U.S.
Geological Survey Minera] Investigations Resource Map MR-90, 19 p.. 1 sheet, scale $1: 2,500,000$.

Cobb, E. H., (comp.), 1984[1985], Map showing occurrences of lead minerals in Alaska: U.S. Geological Survey Mineral Investigations Resource Map MR-91, 11 p., 1 sheet, scale $1: 2,500,000$.

Cruz, E. L., and Cobb, E. H., (comp.), 1984, Map showing occurrences of mercury minerals in Alaska: U.S. Geological Survey Mineral Investigations Resource Map MR-87, 4 p., 1 sheet, scale $1: 2,500,000$.

Cruz, E. L., and Cobb, E. H., (comp.), 1984, Occurrences of tin minerals in Alaska: U.S. Geological Survey Mineral Investigations Resource Map MR 89, scale 1:2.500,000.

\section{Miscellaneous Field Studies Maps}

Detterman, R. L., Case, J. E., and Yount, M. E., 1984, Map showing onshore energy resources of the Chignik and Sutwik Island quadrangles, Alaska: U.S. Geological Survey Miscellaneous Field Studies Map MF 1053-L, 2 sheets, scale $1: 250,000$.

Hamilton, T. D., 1984, Surficial geologic map of the Howard Pass quadrangle, Alaska: U.S. Geological Survey Miscellaneous Field Studies Map MF-1677, 1 sheet, scale 1:2:70,000.

Hamilton, T. D., 1984, Surficial g :ologic map of the Ambler River quadrangle, Alaska: U.S. Geological Survey Miscellaneous Field Studies Map MF-1678, 1 sheet, scale 1:250,000.

Hamilton, T. D., 1984, Surficial g ologic map of the Chandalar quadrangle: U.S. Geological Survey Miscellaneous Field Studies Map MF878-A, scale 1:250,000.

Nelson, S. W., Miller, M. L., Barnes, D. F., Dumoulin, J. A., Goldfarb, R. J., Koski, R. A., Mull, G. C., Pickthorn, W. J., Jansons, Uldis, Hoekzema, R. B., Kurtak, J. M., and Fechner, S. A., 1984, Mineral resource pitential map of the Chugach National Forest, Alaska-Summary report: U.S. Geological Survey Miscellaneous Field Studies Map MF-1645, 24 p., 1 sheet, scale $1: 250,000$.

Sable, E. G., Chapman, R. M., and Tailleur, I. L., 1984, Geologic map of the western KukpowrukNuka rivers region, northwestern Alaska: U.S. Geological Survey Miscellaneou- Field Studies Map MF-1668, 2 sheets, scale 1:63,360.

Sable, E. G., and Mangus, M. D., 1984, Geologic map of the west-central Kukpowruk-Nuka rivers region, northwestern Alaska: U.S. Geological Survey Miscellaneou: Field Studies Map MF-1669, 2 sheets, scale 1:63,360.

Sable, E. G., Mangus, M. D., Morris, R. H., and Dutro, J. T., Jr., 1984, Geologic map of the east-central Kukpowruk-Nuka rivers region, northwestern Alaska: U.S. Geological Survey 
Miscellaneous Field Studies Map MF-1670, 2 sheets, scale 1:63,360.

Sable, E. G., Dutro, J. T., Jr., Morris, R. H., and Tailleur, I. L., 1984, Geologic map of the eastern Kukpowruk-Nuka rivers region, northwestern Alaska: U.S. Geological Survey Miscellaneous Field Studies MF-1671, 2 sheets, scales $1: 63,360$ and $1: 250,000$.

Note: Metallic mineral resources maps of the Middleton Island, Nulato, Unalakleet, Naknek, and Mt. Michelson quadrangles have been reprinted. Also reprinted are fence diagrams for the Sadlerochit Group in the Philip Smith Mountains quadrangle, generalized structure maps of the Colville Group and Lower Cretaceous unconformity, subcrop map at that unconformity, and Jurassic and Lower Cretaceous seismic horizons, as well as isopach maps of Jurassic and possible Lower Cretaceous shale on the North Slope, and a geologic map of the Survey Pass quadrangle. These and other reprints are listed by number in "Publications of the U.S. Geological Survey, 1984."

\section{U.S. Geological Survey authors in outside journals}

Affolter, R. H., and Stricker, G. D., 1984, Geochemistry of selected coal beds from the Beluga coal field, Cook Inlet region, Alaska (abs. 46844): Geological Society of America, Abstracts with Programs, v. 16, no. 5, p. 266.

Antweiler, J. C., and Cathrall, J. B., 1983, The relationship of gold in placer deposits in the Brooks Range, Alaska, to primary gold sources (abs.): Proceedings, Alaska Science Conference, v. 34, p. 94.

Armbrustmacher, T. J., 1984, Rare-earth/thorium deposits associated with a complex of syenitic rocks near Mt. Prindle, east-central Alaska (abs. 47175): Geological Society of America, Abstracts with Programs, v. 16, no. 5, p. 266267.

Bird, K. J., 1984, A comparison of the play-analysis techniques as applied in hydrocarbon resources assessments of the National Petroleum Reserve in Alaska and of the Arctic National Wildlife Refuge, in Masters, C. D., 1984, Petroleum Resource Assessment: Ottawa, Ont., International Union of Geological Sciences Publication 17, p. 63-79.

Box, Stephen, 1984, Implications of a possibly continuous $400 \mathrm{~km}$ long late Early Cretaceous arc-continent collisional belt in NE USSR and NW Alaska for the tectonic development of Alaska, in Howell, D. G., Jones, D. L., Cox, Allan, and Nur, Amos, eds., Proceedings of the Circum-Pacific Terrane Conference, v. XVIII of Stanford University Publications in the Geological Sciences, p. 33-35.

Brew, D. A., 1984, Bedrock geology and mineral resources of Glacier Bay National Park and
Preserve, in A century after Muir-The scientific adventure, Proceedings of the first Glacier Bay science symposium: U.S. Department of the Interior, $10 \mathrm{p}$.

Cady, J. W., 1984, Ocean terranes of interior and western Alaska-Evidence for thick cr'st of intermediate density, in Howell, D. G., Jones, D. L., Cox, Allan, and Nur, Amos, eds., Proceedings of the Circum-Pacific Trrane Conference, v. XVIII of Stanford University Publications in the Geological Sciences, p. 4143.

Carlson, Christine, and Pavlis, T. L., 1984, Significance of metamorphic complexes associated with the Peninsular terrane, southern Alaska, in Howell, D. G., Jones, D. L., Cox, Allan, and Nur, Amos, eds., Proce.edings of the Circum-Pacific Terrane Conference, v. XVIII of Stanford University Publications in the Geological Sciences, p. 47-49.

Decker, John, Reifenstuhl, R. R., and Coonr`d, W. L., 1984, Compilation of geologic data from the Russian Mission A-3 quadrangle, Alaska: Alaska Division of Geological and Geophysical Surveys Report of Investigations 84-19, 1 sheet, scale $1: 63,360$.

Desborough, G. A., and Criddle, A. J., 1984, Bowierite, a new rhodium-iridium-platinum sulfide in platinum-alloy nuggets, Gondnews Bay, Alaska: The Canadian Mineralogist, v. 22, pt. 4, p. 543-552.

Dickinson, K. A., and Campbell, J. A., 1984, Uranium geology of the Tertiary Kootznahoo Formation of the southern part of the Admiralty Trough, southeastern Alaska: Journal of the Alaska Geological Society, v. 4, p. 1-11.

Dickinson, K. A., and Cunningham, Kenneth, 1984, Death Valley, Alaska, uranium deposit (abs. 47176): Geological Society of Anerica, Abstracts with Programs, v. 16, no. 5, p. 278,

Donovan, J. T., Hendricks, J. D., Roberts, A. A., and Eliason, P. T., 1984, Low-altitude aeromagnetic reconnaissance for petroleum in the Arctic National Wildlife Refuge, Alaska: Geophysies, v. 49 , no. 8 , p. 1338-1353.

Dutro, J. T., Jr., and Jones, D. L., 1984, Paleotectonic setting of the Carbonifer sus of Alaska: International Congress on $\mathrm{C}$-rboniferous Stratigraphy and Geology, v. 3, nn. 9, p. 229-234.

Fisher, M. A., and von Heune, Roland, 1984, Geophysical investigations of a suture zoneThe Border Ranges fault of southern Alaska: Journal of Geophysical Research, v. 89, no. B13, p. 11333-11357.

Forrest, Kimball, Sawkins, F. J., and Rye, R. O., 1984, The Lik deposit, western Brooks Range, Alaska-Sedex mineralization along axiel vent sites in a structural basin (abs. 37209): Geological Society of America, Abstracts with 
Programs, v. 16, no. 6, p. 511. [tonnage for reserves ]

Foster, H. L., Laird, Jo, and Cushing, G. W., 1984, Thrust faulting in the Eagle A-1 quadrangle, Alaska, and its implications for the tectonic history for the Yukon-Tanana Upland (abs.): EOS, Transactions of the American Geophysical Union, v. 65 , no. 15 , p. 291.

Goldfarb, Richard, Pickthorn, William, and Sutley, Stephen, 1984, Metalliferous middle Tertiary sedimentary rocks, Kayak Island, Gulf of Alaska (abs. 46861): Geological Society of America, Abstracts with Programs, v. 16, no. 5, p. 286.

Goldfarb, Richard, Pickthorn, William, and Tripp, Richard, 1984, The distribution of epigenetic gold-quartz lodes and base metal lodes within the Valdez Group, Alaska (abs. 46862): Geological Society of America, Abstracts with Programs, v. 16 , no. 5, p. 286.

Hillhouse, J. W., and Grommé, C. S., 1984, Northward displacement and accretion of Wrangellia, new paleomagnetic evidence from Alaska (abs.): EOS, Transactions of the American Geophysical Union, v. 65, no. 7, p. 60.

Hopkins, D. M., 1984, Application of a preconcentration method for trace metal analysis of waters in the exploration for massive sulfide deposits in areas of dilute runoff (abs. 43866): Geological Society of America, Abstracts with Programs, v. 16, no. 5, p. 290.

Lange, I. M., and Nokleberg, W. J., 1984, Massive sulfide deposits of the Jarvis Creek terrane, Mt. Hayes quadrangle, eastern Alaska Range (abs. 46928): Geological Society of America, Abstracts with Programs, v. 16, no. 5, p. 294.

Mamet, B. L., and Armstrong, A. K., 1984, The Mississippian-Pennsylvanian boundary in the northeastern Brooks Range, Arctic Alaska: International Congress on Carboniferous Stratigraphy and Geology, p. 428-436.

Miller, T. P., 1984, Mineral resources-Arctic Alaska, in Westermeyer, W. E., and Shusterich, K. M., eds., United States Arctic interests-The 1980's and 1990's: New York, Springer, p. 5974.

Nokleberg, W. J., Berg, H. C., Lange, I. M., Grybeck, Donald, and Jones, D. L., 1984, Metallogenesis and accreted tectonostratigraphic terranes of Alaska (abs.), in Symposium-Cordilleran geology and mineral exploration; status and future trends, Vancouver, B.C.: Geological Association of Canada, Cordilleran Section, p. 30-31.

Odum, J. K., 1984, Geological and geotechnical analysis of four U.S. Geological Survey drill holes in the coal-bearing Tyonek Formation, Cook Inlet region, Alaska (abs. 46840):
Geological Society of America, Abstracts with Programs, v. 16, no. 5, p. 326.

Page, R. A., Fuis, G. S., Mooney, W. D., Nokleberg, W. J., Plafker, George, and $\mathrm{C}$-mpbell, D. L., 1984, Crustal transect of accreted tectonostratigraphic terranes in the Chugach Mountains and Copper River Basin, AlaskaInitial results of TACT (abs.): EOS, Transactions of the Americen Geophysical Union, v. 65 , no. 45 , p. 985 .

Plafker, George, Bruns, T. R., Wolfe, J. A., McCoy Scott, Jr., and Keller, Gerta, 1984, Model for the origin of the Yakutat Bloc', an accreting terrane in the northern Gulf of Alaska: Geology, v. 12, no. 9, p. 563-567.

Rubin, C. M., 1984, Geologic setting and sulfide mineralization of the Smicker deposit, southcentral Brooks Range, Alaska (abs.): Geological Society of America, Abstracts with Programs, v. 16, no. 6, p. 640.

Shacklette, H. T., 1984, Absorption of gold by plants (abs.): Geological Associaticn of Canada, Program with Abstracts, v. 9, p. 104. [Not exclusively Alaska ]

Silberman, M. L., Madden, D. L., Mitchell, P. A., and Hoekzema, R. B., 1984, Characteristics of lode-gold deposits in the Valdez Group, western Prince William Sound, Alaska (abs. 41958): Geological Society of America, Abstracts with Programs, v. 16, no. 5, p. 332.

Watterson, J. R., and Antweiler, J. C., 1984, How gold placers originate from auriferous schist $-a$ theory (abs. 47109): Geological Society of America, Abstracts with Prograns, v. 16, no. 5, p. 339 .

Winkler, G. R., 1984, The Peninsula" and Chugach terranes, southern Alaska-Their compositions and timing of their amalgamation (abs.): Geological Society of America Abstracts with Programs, v. 14, no. 6, p. 354.

Wong, F. L., 1984, Heavy minerals in surficial sediments from lower Cook Inlet, Alaska: GeoMarine Letters, v. 4, no. 1, p. 25--30.

\section{BUREAU OF MINES}

Barker, J. C., 1984, Concentrations of cobalt and other metals in the western Cr $\approx$ zy Mountains, interior Alaska: U.S. Bureau of Mines Open File Report 213-84, 44 p., 3 sheets, scale $1: 63,360$.

Barker, J. C., and Swainbank, R. C., 1985, A tungsten-rich porphyry molybder'lm occurrence at Bear Mountain, northeast Alaska: U.S. Bureau of Mines Open File Report 8-85, 64 p.

Brown, L. L., 1984, Appraisal of eritical minerals from northwestern and Alaskan resources, in Pederson, J. R., ed., Bureau of Mines research 84-A summary of siginificant results in mineral technology and economirs: Bureau of Mines Special Publiations 2-84, p. 56-57. 
Dahlin, D. C., Kirby, D. E., and Brown, L. L., 1984, Chromite deposits along the Border Ranges fault, southern Alaska; Part 2-Mineralogy and results of beneficiation tests: U.S. Bureau of Mines Information Circular 8891, 37 p.

DOWL Engineers/PLANgraphics, Inc., 1984, Mining properties acquisition costs-Kantishna Hills, Dunkle Mine Study Area, Denali National Park, Alaska: Bureau of Mines Open File Report 12884, 179 p.

Foley, J. Y., and Barker, J. C., 1984, Chromite deposits along the Border Ranges fault, southern Alaska; Part 1-Field investigations and descriptions of chromite deposits: U.S. Bureau of Mines Information Circular 8890, $57 \mathrm{p}$.

Foley, J. Y., Hinderman, Toni, Kirby, D. E., and Moardock, C. L., 1984, Chromite occurrences in the Kaiyuh Hills, west-central Alaska: U.S. Bureau of Mines Open File Report 178-84, 20 p.

Hoekzema, R. B., 1984, Strategic and critical mineral development potential of the Chugach National Forest, southcentral Alaska: U.S. Bureau of Mines Open File Report 215-84, 64 p., 1 sheet, scale 1:250,000.

Jansons, Uldis, Hoekzema, R. B., Kurtak, J. N., and Fechner, S. A., 1984, Mineral occurrences in the Chugach National Forest, southeentral Alaska: Bureau of Mines Mineral Land Assessment 5-84, 218 p., appendix, 2 map sheets, scale 1:250,000.

Jeske, R. E., 1984, Regional distribution of critical and strategic minerals in the Kanitshna Hills area, Denali National Park and Preserve, Alaska: U.S. Bureau of Mines Open File Report 214-84, 97 p., 4 sheets, scale 1:63,360.

Levell, J. H., Thornsberry, V. V., Salisbury, W. G., and Smith, D. A., 1984, Appendices to 1983 mineral resource studies-Kantishna Hills and Dunkle Mine areas, Denali National Park and Preserve, Alaska: Bureau of Mines Open File Report 129(2)-84, 809 p.

Meyer, M. P., 1985, Mineral investigation of the Iditarod-George Planning Block, central Kuskokwim area, Alaska: U.S. Bureau of Mines Open File Report 9-85, 232 p., 4 sheets, scale $1: 250,000$.

Mulligan, J. J., 1984, Coals in Alaska: American Institute of Mining Engineers Transactions, v. 274 , p. 2036-2040.

Roberts, W. S., 1984, Cobalt-bearing deposits related to mineral terranes of Alaska: U.S. Bureau of Mines Open File Report 175-84, 10 p.

Roberts, W. S., 1984, Economic potential for chromium, platinum, and palladium in the Mount Hurst ultramafics, west-central area, Alaska: Bureau of Mines Open File Report 2284,52 p.

Salisbury and Dietz, Inc., 1983[1984], 1983 Mineral resources studies, Kantishna Hills and Dunkle Mines areas, Denali National Park and
Preserve, Alaska: Bureau of Mines Open File Report 129-84, 3 v., 1,080 p.

Sherman, G. E., and Jansons, Uldis, 1984, Feasibility of gold and copper mining in the Chugach National Forest, Alaska: Bur sau of Mines Open File Report 125-84, 55 p.

Skudrzyk, F. J., 1984, Preliminary studies of the effectiveness of water jet cutting on frozen ground: Contract report prepared under contract No. B4620191, Mineral Irdustry Research Laboratory, $35 \mathrm{p}$.

Southworth, D. D., 1984, Columbium in the goldand tin-bearing placer deposits near Tofty, Alaska: U.S. Bureau of Mines Open File Report 174-84, 25 p.

Southworth, D. D., 1984, Geologic and geoch?mical investigation of the "Nail" allochthon, eastcentral Alaska: U.S. Bureau of Mines Open File Report 176-84, 26 p.

Still, J. C., 1984, Stream sediment, float, and bedrock sampling in the Porcupine mining area, southeast Alaska: U.S. Bureau of Mines Open File Report 173-84, 12 p.

Still, J. C., 1984, Copper, gold, and platinum sample returns from the Klukwan mafic/ultramafic complex, southeast Alaska: Bureau of Mines Open File Report 21-84, 53 p.

Still, J. C., 1984, Stratiform massive sulfide deposits in the Mt. Henry Clay area, southeast Alaska: Bureau of Mines Open File Report 11884,65 p. [Deposit similar to Windy Craggy]

Thornsberry, v. V., McKee, C. J., and Salisbury, W. G., eds., 1984, 1983 mineral resource studiesKantishna Hills and Dunkle Mine areas, Denali National Park and Preserve, Alaska: Bureau of Mines Open File Report 129(1), v. 1, 125 p.

U.S. Bureau of Mines, 1984, Bureau of Mines research 84-A summary of significant results in mineral technology and economics: U.S. Bureau of Mines Special Publications 2-84, $138 \mathrm{p}$.

\section{BUREAU OF LAND MANAGEMEN'T}

U.S. Bureau of Land Management, 1984, Alaska's wild and scenic rivers managed by the Bureau of Land Management: pamphlet.

A listing of available noncompetitive oil and gas lease lands in Alaska is available from the Public Information Office in the Bureau's Anchorage office. The following reports are also available through that of fice:

Bureau of Land Management, 1984, P rposed Resource Management Plan-Final Elvironmental Impact Statement for the Steese National Conservation Area: Feirbanks District Office, $321 \mathrm{p}$.

Bureau of Land Management, 1984, P:oposed Resource Management Plan-Final Frviron- 
mental Impact Statement for White Mountains National Recreation Area: Fairbanks District Office, $317 \mathrm{p}$.

\section{NATIONAL PARK SERVICE}

The following reports are available from the Park Service's Anchorage of fice:

Final General Management Plans for: Lake Clark National Park and Preserve; Glacier Bay National Park and Preserve; and Kenai Fjords National Park

Statement for Management for: Noatak National Preserve; Cape Krusenstern National Monument; Gates of the Arctic National Park and Preserve

Land Protection Plans for: Sitka National Historical Park; Klondike Gold Rush National Historical Park

National Park Service, 1984, Final Environmental Impact Statement for the Kantishna Hills/Dunkle Mine Study Report: 616 p.

See also West and Deschu (1984) under U.S. Fish and Wildlife Service publications.

\section{U.S. FISH AND WILDLIFE SERVICE}

All reports listed below are available from the Alaska Regional Office in Anchorage.

U.S. Fish and Wildlife Service, 1984, Alaska Peninsula National Wildlife Refuge Draft Comprehensive Conservation Plan, Environmental Impact Statement, and Wilderness Review: Anchorage, Region 7, $196 \mathrm{p}$.

U.S. Fish and Wildlife Service, 1984, Becharof National Wildlife Refuge Draft Comprehensive Conservation Plan, Environmental Impact Statement, and Wilderness Review: Anchorage, Region 7, 159 p.

U.S. Fish and Wildlife Service, 1984, Izembek National Wildlife Refuge Draft Comprehensive Conservation Plan, Environmental Impact Statement, and Wilderness Review: Anchorage, Region 7, 123 p.

U.S. Fish and Wildlife Service, 1984, Kenai National Wildlife Refuge Draft Comprehensive Conservation Plan, Environmental Impact Statement, and Wilderness Review: Anchorage, Region 7, 198 p.

U.S. Fish and Wildlife Service, 1984, Geologist's report, p. 19 in Federal Land Policy and Management Act Section 204(c) ReportWithdrawal of lands adjacent to Arctic National Wildlife Refuge: Bureau of Land Management, Alaska State Office, Anchorage, Case File no. F-82319.

U.S. Fish and Wildlife Service, 1985, Kenai National Wildlife Refuge Final Comprehensive Conser- vation Plan, Environmental Impact Statement and Wilderness Review: Anchcrage, Region 7, $205 \mathrm{p}$.

West, R. L., and Deschu, N. A., 1984, Kantishna Hills heavy metals investiçations, Denali National Park, 1983: report prepared under Interagency Agreement No. 14-16-007-82-5524 between the National Park Service and the U.S. Fish and Wildlife Service, Anchorage, 42 p.

\section{DEPARTMENT OF AGRICULTURE- FOREST SERVICE:}

Forest Service, 1984, Draft Environmental Impact Statement-Quartz Hill molybdenum project mine development: Alaska Region Administrative Document $133,482 \mathrm{p}$. and appendices A-Q.

Forest Service, 1985, Final Environmental Impact Statement-Admiralty Island National Monument Proposed Boundary Change: Alaska Region Administrative Report $129 \mathrm{~b}, 114 \mathrm{p}$. and appendices $\mathrm{A}-\mathrm{G}$.

Forest Service, 1984, Tongass Land Management Plan Evaluation Report: Alaska Region Administrative Document 139, 166 p. and appendices $\mathrm{A}-\mathrm{D}$.

Forest Service, 1984, Final Chugach National Forest Land and Resource Management Plan: Alaska Region Administrative Document 127B, $184 \mathrm{p}$. and appendices A-F.

Forest Service, 1984, Final Environmental Impact Statement-Chugach National Forest Plan: Alaska Region Administrative Document 127A, 244 p. and appendices A-E.

\section{DEPARTMENT OF ENERGY}

U.S. Department of Energy, 19ع4, Arctic and offshore research subprogram-Reducing the uncertainties about producing oil and gas in the Alaskan Arctic: U.S. Department of Energy, Morgantown Energy Technology Center, Topical Report, 33 p.

Weaver, T. A., and others, comps., 1983 [1984], The geochemical atlas of Alaska: Report GJBX32(83), 61 oversize pages and 6 transparent overlays. [For information about availability of paper copies, contact T. A. We?ver Earth and Space Sciences Div., MS-33E. Los Alamos National Lab., P.O. Box 1663, I os Alamos, NM 87545; refer to LANL No. LA-9997-MS and PR No. 84-13.]

Information about Department of Energy NURE reports concerning Alaska can be obtained from the Open-File Services Section, U.S. Geslogical Survey, Building 41, MS 306, Box 25046, Federal Center, Denver, CO 80225. Magnetic tenes containing Airborne Radiometric and Magnetic Survey data and Hydrogeochemical and Stream Sediment Reconnaissance data are available through the U.S. 
Geological Survey's EROS Data Center, Sioux Falls, SD 57198. The Department of Energy/Bendix Field Engineering Corportation Technical Library in Grand Junction has a complete set of NURE reports for public inspection only; it no longer sells reports.

\section{OTHER FEDERAL AGENCIES}

U.S. National Advisory Committee on Oceans and Atmosphere, 1984, A special report to the President and Congress-The exclusive economic zone of the United States-Some immediate policy issues: $109 \mathrm{p}$.

U.S. Environmental Protection Agency and Department of the Interior [National Park Service, Bureau of Land Management, and Fish and Wildlife Service], 1984, Final Environmental Impact Statement, Red Dog Mine Project, Northwest Alaska [prepared in cooperation with the U.S. Army Corps of Engineers, with technical assistance from $\mathrm{OH}$ Water Engineers, Inc.]: V. I (text) and V. II (appendices), not consecutively paginated.

\section{NON-FEDERAL PUBLICATIONS}

Alaska Construction and Oil, 1984, Alaska Mining: v. 25 , no. 3 , p. 31 . [Unga Island, Tobin and Little Squaw Creeks]

Alaska Construction and Oil, 1984, Speakers call for resource development: v. 25 , no. 4 , p. $50-$ 51.

Alaska Construction and Oil, 1984, Milne Point to produce in 1986: v. 25 , no. 4 , p. 44.

Alaska Division of Geological and Geophysical Surveys, 1984, Mining laws applicable in Alaska: Information Circular 14, $34 \mathrm{p}$.

Alaska Division of Geology and Geophysical Surveys, 1984, Alaska Mines and Geology [newsletter]: v. 33, nos. 1, 2, 16 p. each.

Alaska Division of Geological and Geophysical Surveys, 1985, Alaskan companies and prospectors, 1983 (rev. ed.): Information Circular 7, 45 p.

Alaska Division of Geological and Geophysical Surveys, 1984, Short notes on Alaskan geology 1982-83: Professional Report 86, 48 p.

Alaska Miner (the journal of the Alaska Miners Association): see all issues for 1984 for miscellaneous information.

Albanese, M. D., 1984, Geochemical reconnaissance of the Upper Chena River area, central Alaska-Analytical data on streamsediment, pan concentrate, and rock samples: Alaska Division of Geological and Geophysical Surveys Report of Investigations 84-4, 30 p., 1 pl., scale $1: 63,360$.

Albanese, M. D., 1984, Geochemical reconnaissance of the Livengood $\mathrm{B}-3, \mathrm{~B}-4, \mathrm{C}-3$ and C-4 quadrangles, Alaska-Summary of data on stream-sediment, pan-concentrate, and rock samples: Alaska Division of Geological and
Geophysical Surveys Report of Investigations 83-1, 55 p., 4 sheets, scale 1:63,360.

Albanese, M. D., 1984, Bedrock geologic map of the Livengood B-4 quadrangle, Alaska: Alaska Division of Geological and Geophysical Surveys Report of Investigations 83-3, 1 sheet, scale $1: 63,360$.

Albers, J. P., and Fratricelli, L. A., 1984, Metallogenic trends and oil and gas fie' $\mathrm{As}$ of the northeast quadrant, circumpacific $r$ gion, in Howell, D. G., Jones, D. L., Cox, Allan, and Nur, Amos, eds., Proceedings of the Ci-cumPacific Terrane Conference, v. XVIII of Stanford University Publications in the Geological Sciences, p. 10-16.

Allegro, G. L., 1984, Geology of the Old Smoky Prosepect, Livengood C-4 quadrangle, Alaska: Alaska Division of Geological and Geopr vsical Surveys Report of Investigations 84-1, 10 p., 1 pl., scale $1: 25,000$.

Allegro, G. L. 1984, Gilmore Dome "stratiform" tungsten occurrences, Fairbanks mining district, Alaska (abs. 47001): Geological Society of America, Abstracts with Programs, v. 16 , no. 5 , p. 266 .

American Gold News, 1985, Alaska's Queenstake resources: v. 52 , no. 2 , p. 11 . [Chichagof property]

Anonymous, 1984, Cominco on the hunt with Red Dog and Buckhorn: Western Miner, v. 57, no. 4, p. 21-22.

Anonymous, 1984, Diverse activities-Strong base for Noranda: Western Miner, v. 57, no. 4, p. 37.

Barnwell, W. W., and Pearson, K. S., comps., 1984, Alaska's resource inventory, 1984: Alaska Division of Geological and Geophysical S trveys Special Report 36, 62 p.

Barrie, T. C. P., 1984, Geology of the Khayyem and Stumble-on massive sulfide deposits, Prince of Wales Island, Alaska (abs. 46311): Geo'ngical Society of America, Abstracts with Prorrams, v. 16 , no. 5 , p. 268.

Bashin, Bryan, 1984, Bacteria crystallizes gold: American Gold News, v. 51, no. 11, p. 1.

Bundtzen, T. K., and Eakins, G. R., 1984, AlaskaPrecious metals continue to dominate 1983 exploration: Mining Engineering, v. 36, no. 5, p. 438-442.

Bundtzen, T. K., and others, 1984, Alaska's mineral industry, 1983: Alaska Division of Geological and Geophysical Surveys Special Report 33, $56 \mathrm{p}$.

California Mining Journal, 1984, Alaska go'd find could be rich: v. 53 , no. 11 , p. 26. [Johnson River ]

California Mining Journal, 1984, EPA to enforce new placer rules in Alaska: v. 53, no. 11, p. 60.

California Mining Journal, 1984, Offshore gold placer to be developed: v. 53 , no. 11, p. 62 . [Nome area ] 
California Mining Journal, 1984, Alaska mining developments: v. 54 , no. 2 , p. 2 .

California Mining Journal, 1984, Joint venture to mine Candy Mountain vein: v. 54, no. 3, p. 9.

Churkin, Michael, Jr., Wallace, W. K., and Moore, T. E., 1985, Alaska-an explorationist's jambolaya: American Association of Petroleum Geologists Bulletin, v. 69, no. 2, p. 244.

Cole, T., ed., 1984, Nome-City of the golden beaches: Alaska Geographic, v. 11, no. 1, $183 \mathrm{p}$.

Davis, Neil, 1984, Alaska/Energy: Fairbanks, University of Alaska Press, 530 p.

Decker, John, and Dillon, J. T., 1984, Interpretation of regional aeromagnetic signatures along the southern margin of the Brooks Range, Alaska (abs. 44314): Geological Society of America, Abstracts with Programs, v. 16, no. 5, p. 278.

Decker, John, Reifenstuhl, R. R., and Coonrad, W. L., 1984, Compilation of geologic data from the Bethel D-3 quadrangle, Alaska: Alaska Division of Geological and Geophysical Surveys Report of Investigations $84-18,1$ sheet, scale 1:63,360.

Decker, John, Reifentstuhl, R. R., and Coonrad, W. L., 1984, Compilation of geologic data from the Iditarod A-5 quadrangle, Alaska: Alaska Division of Geological and Geophysical Surveys Report of Investigations 84-17, 1 sheet, scale $1: 63,360$.

Decker, John, Reifenstuhl, R. R., and Coonrad, W. L., 1984, Compilation of geologic data from the Sleetmute A-5 quadrangle, southwestern Alaska: Alaska Division of Geological and Geophysical Surveys Report of Investigations 84-29, 1 sheet, scale 1:63,360.

Decker, John, Reifenstuhl, R. R., and Coonrad, W. L., 1985, Compilation of geologic data from the Sleetmute A-7 quadrangle, southwestern Alaska: Alaska Division of Geological and Geophysical Surveys Report of Investigations 85-1, 1 sheet, scale 1:63,360.

Decker, John, Robinson, M. S., Murphy, J. M., Reifenstuhl, R. R., and Albanese, M. D., 1984, Geologic map of the Sleetmute A-6 quadrangle, Alaska: Alaska Division of Geological and Geophysical Surveys Report of Investigations 84-8, 1 sheet, scale 1:40,000.

Eakins, G. R., and others, 1985, Alaska's mineral industry, 1984: Alaska Division of Geological and Geophysical Surveys Special Report 38, 57 p.

Economides, M. J., and Arce, G. N., 1984, Geothermal development in Alaska-An engineering and geologic analysis: Geothermics, v. 13, no. 3, p. 241-264.

Engineering and Mining Journal, 1984, Mine projects move ahead despite the tangle of legislation: v. 185 , no. 11 , p. 9 and 132 .

EOS, Transactions of the American Geophysical Union, 1984, Alaskan transect: v. 65, no. 9., p. 75 .
Fernette, Gregory, and Cleveland, Gaylord, 1984, Geology of the Miss Molly molybdenum prospect, Tyonek C-6 quatrangle, Alaska: Alaska Division of Geologica] and Geophysical Surveys Professional Report 86, p. 35-41.

Forrest, Kimball, Sawkins, F. J., and Rye, R. O., 1984, The Lik deposit, western Brooks Range, Alaska-Sedex mineralization along axial vent sites in a structural basin (abs.): Geological Society of America, Abstract - with Programs, v. 16 , no. 6 , p. 511 .

Gilbert, W. G., Nye, C. J., and Sherwood, K. W., 1984, Stratigraphy, petrology and geochemistry of Upper Triassic rocks from the Pingston and McKinley terranes, central Alaska Range: Alaska Division of Geological and Geophysical Surveys Report of Investigations 84-30, 20 p.

Harris, Mark, 1984, Cook Inlet holds promise of new Alaska gold bonanza: Alaska Construction and Oil, v. 25, no. 7, p. 28,30, 32, 34 .

Harris, Mark, 1984, The five 'bests bets' gear up: Alaska Construction and Oil, v. 25, no. 7 , p. 16, $18,20,22,24,26$.

Harris, Mark, 1984, New generation of North Slope development: Alaska Construction and Oil, v. 25 , no. 11 , p. 16-27.

Harris, T. D., and Atkinson, W. W. , Jr., 1984, Geology of the Round Top Eorphyry coppermolybdenum deposit, west-central Alaska (abs.): Geological Society of America, Abstracts with Programs, v. 16, no. 6, p. 530.

Henning, M. W., Meyer, J., Kornbrath, R., and Krouskop, D., 1984, Geologic and gravity evaluation of oil and gas Eotential of the Minchumina Basin, Alaska (abs. 46945): Geological Society of Americs, Abstracts with Programs, v. 16, no. 5, p. 289.

Jones, B. C., and Hiles, R. M., 1984, Oil and gas developments in Alaska in 1983: American Association of Petroleum Geologists Bulletin, v. 68 , no. 10 , p. 1266-1272.

Mangone, G. J., 1984, American Str ntegic Minerals: New York, Crane, Russak, 153 p.

MeMillin, S. L., 1984, Geology, alteration, and sulfide mineralization of Shoep Mountain, southcentral Alaska (abs. 45299): Geological Society of America, Abstracts with Programs, v. 16 , no. 5 , p. 321 .

Merritt, D. D., and Belowich, N. A., 1984, Coal geology and resources of the Matanuska Valley: Alaska Division of Geological and Geophysical Surveys Report of Investigations 84-25, 6 p., 2 sheets, scale 1:500,000.

Mining Activity Digest: 1984, New development highlights: v. 11 , no. 5, p. 2-3. [Red Dog]

Mining Activity Digest, 1984, U.S. mine plant activity-Alaska: v. 11 , no. 5, p. 9-10. [Greens Creek]

Mining Journal, 1984, Industry in action-Red Dog target: v. 302 , no. 7753 , p. 194 .

Mining Journal, 1984, Industry inaction-Alaskan gold involvement for Marubeni, and Quartz Hill 
indefinite postponement: v. 302 , no. 7758 , p. 285.

Molton, P. M., Fassbender, A. G., and Brown, M. D., 1984, Direct conversion of peat to liquid fuel: The Northern Miner, v. 16, no. 1, p. 1419.

Murphy, J. M., Decker, John, and Coonrad, W. L., 1984, Compilation of geologic data from the Bethel D-2 quadrangle, Alaska: Alaska Division of Geological and Geophysical Surveys Report of Investigations 84-28, 1 sheet, scale $1: 63,360$.

Mutschler, F. E., Griffin, M. E., Stevens, D. S., and Shannon, S. S., Jr., 1984, Precious metal deposits related to alkaline igneous rocks in the North American Cordillera (abs. 45364): Geological Society of America, Abstracts with Programs, v. 16, no. 6, p. 606.

Myers, G. L., 1984, Geology of the Cu-Fe-Au skarns of Kasaan Peninsula, southeast Alaska (abs. 45299): Geological Society of America, Abstracts with Progams, v. 16, no. 5, p. 324.

Newberry, Rainer, 1984, Metallogenesis of skarn deposits in Alaska (abs. 45304): Geological Society of America, Abstracts with Programs, v. 16 , no. 5 , p. 325 .

Nye, C. J., Queen, L. D., and Motyka, R. J., 1984, Geologic map of the Makushin geothermal area, Unalaska Island, Alaska: Alaska Division of Geological and Geophysical Surveys Report of Investigations $84-3,2$ pls., seale $1: 24,000$.

Oil and Gas Journal, 1984, Beaufort lists strike; Mukluk plugged: v. 82 , no. 5, p. 74-75.

Oil and Gas Journal, 1984, Exxon wants big expansion for units on N. Slope: v. 82 , no. 8, p. 3435.

Oil and Gas Journal, 1984, Conoco marks N. Slope field for development: v. 82, no. 10, p. 48-49. [Milne Point]

Oil and Gas Journal, 1984, Exxon: N. Slope gas/ condensate field is a giant: v. 82 , no. 11, p. 30 . [Pt. Thomson]

Oil and Gas Journal, 1984, Alaskan North Slope operators push projects to recover thirdgeneration oil: v. 82 , no. 26 , p. $55-58$.

Oil and Gas Journal, 1984, Clark: Seismic surveys don't hurt Arctic refuge: v. 82, no. 27, p. 25.

Oil and Gas Journal, 1984, ARCO sees long period of oil self-sufficiency: v. 82 , no. 19 , p. 82 .

Oil and Gas Journal, 1984, Expansion of Kuparuk field advancing: v. 83 , no. 31 , p. 104; see also no. 30, p. 4.

Oil and Gas Journal, 1984, Cononco to seek bids for Milne Point: v. 82 , no. 38, p. 58.

Oil and Gas Journal, 1984, ARCO to boost Kuparuk River output: v. 82 , no. 34 , p. 68-70.

Oil and Gas Journal, 1984, Sohio earmarks $\$ 2$ billion for N. Slope projects: v. 82, no. 41, p. 52 .

Oil and Gas Journal, 1985, MMS selects sale tracts in Alaska's Bristol Bay: v. 83, no. 5, p. 32. [Sale 92 area]
Pankonien, L. J., 1984, North Slope news: World Oil, v. 198, no. 5, p. 25. [Milne Point]

Pankonien, L. J., 1984, What's happening in the United States-Big projects on tap: Wcrld Oil, v. 199, no. 6, p. 25. [Endicott, Prudhoe Bay, Lisburne projects ]

Pratt, Fred, 1984, Suction dredge restrictions on Alaskan river: American Gold News, v. 51, no. 5 , p. 1 .

Pratt, Fred, 1984, Massive Red Dog ore deposit could see production by 1988 : Canadian Mining Journal, v. 105 , no. 11 , p. 28-30.

Queen, L. D., 1984, Lithologic log and hydrothermal alteration of core from the Makushin geothermal area, Unalaska Island, Alaska: Alaska Division of Geological and Geophysical Surveys Report of Investigations 84-23, 8 p., 1 sheet.

Queen, L. D., and Motyka, R. J., 1984, Chenges in the Makushin geothermal system-e"idence from alteration mineralogy (abs. 46991): Geological Society of America, Abstracts with Programs, v. 16, no. 5, p. 329.

Reifenstuhl, R. R., Robinson, M. S., Smith、T. E., Albanese, M. D, and Allegro, G. A., 1984, Geologic map of the Sleetmute B-6 quadrangle, Alaska: Alaska Division of Geological and Geophysical Surveys Report of Invest ?ations 84-12, 1 sheet, scale $1: 40,000$.

Ricea, P. M., and Bradshaw, P. M., 1984, TAPS machinery monitory program - 2 (concl ision)Advance features mark trans-Alaskan pipeline system's machinery-monitoring program: Oil and Gas Journal, v. 82, no. 34, p. 100-10\%.

Roberts, W. S., 1984, Economic potential for chromium, platinum, and palladium in the Mount Hurst ultramafics, west centrel area, Alaska (abs. 46912): Geological Society of America, Abstracts with Programs, v. 16, no. 5, p. 330.

Robinson, S. M., 1984, Rock, pan concentrete, and stream-sediment geochemistry, Sleetmute A-6 quadrangle, Alaska: Alaska Division of Geological and Geophysical Surveys Renort of Investigations 84-7, $1 \mathrm{pl}$., scale $1: 40,000$.

Robinson, S. M., 1984, Rock, pan-concentrete, and stream-sediment geochemistry, Sleetmute B-5 quadrangle, Alaska: Alaska Division of Geological and Geophysical Surveys Renort of Investigations 84-9, 1 pl., scale $1: 40,000$.

Robinson, S. M., [and others], 1984, Geologic map of the Sleetmute $b-5$ quadrangle, Alaska: Alaska Division of Geological and Geophysical Surveys Report of Investigations 84-1C: 1 pl., scale $1: 40,000$.

Robinson, S. M., 1984, Rock, pan-concentrete, and stream-sediment geochemistry, Sleetmute B-6 quadrangle, Alaska: Alaska. Division of Geological and Geophysical Surveys Rrnort of Investigations 84-11, 1 sheet, scale 1:63.360. 
Satkoski, J. J., Shannon, S. S., Jr., Mutschler, F. E., MeCollum, L .B., and McCollum, M. B., 1984, Tectonic setting of Mesozoic alkaline rockrelated precious metal systems of the North American Cordillera (abs. 38257): Geological Society of America, Abstracts with Programs, v. 16 , no. 6, p. 644 .

Shirley, Kathy, 1984, Traps, basin attract Alaska bids: American Association of Petroleum Geologists Explorer, v. 5, no. 14, p. 18-19.

Sims, John, 1984, Alaska mining in 84-Optimism returns: Alaska Construction and Oil, v. 23, no. 1 , p. 49-54.

Sims, J. F. M., and Green, C. B., 1985, Future of Alaskan mining discussed: Mining Engineering, v. 37 , no. 1 , p. 15-18.

Skillings' Mining Review, 1984, Northwest RegionAlaska: v. 73 , no. 12 , p. 11-12.

Skillings' Mining Review, 1984, Powerco buys mining option on six Alaskan offshore leases: v. 73 , no. 19 , p. 6

Skillings' Mining Review, 1984, Noranda, Candy Mtn. Gold Mines Ltd. begin joint venture: $v$. 37 , no. 41 , p. 18 .

Smith, T. N., 1984, Petroleum development, North Slope of Alaska: Alaska Mines and Geology, v. 33 , no. 4 , p. $1-4$.

Smith, T. N., Blodgett, R. B., and Clough, J. G., 1984, Preliminary analysis of the petroleum potential and stratigraphy of the Holitna Basin, southwest Alaska (abs. 46935): Geological Society of America, Abstracts with Programs, v. 16 , no. 5 , p. 334 .

Smith, T. N., Clough, J. G,, Meyer, J. F., and Blodgett, R. B., 1985, Petroleum potential and stratigraphy of the Holitna Basin, Alaska (abs.) American Association of Petroleum Geologists Bulletin, v. 69, no. 2, p. 308.

Southworth, D. D., 1984, Red Mountain, a southeastern Alaska-type ultramafic complex in southwestern Alaska (abs. 44277): Geological Society of America, Abstracts with Programs, v. 16, no. 5, p. 334 .

Stern, E. J., Zantop, H. al F., and Reynolds, R. C., 1984, Clay mineralogy and carbon nitrogen chemistry of the Lik and Competition Creek zinc-lead-silver prospects, DeLong Mountians, Alaska: Economic Geology, v. 79, no. 6, p. 1406-1411.

Szumigala, D. J., 1984, Geology and geochemistry of the Tin Creek scarn prospects, Farewell mineral belt, southern Alaska Range, Alaska (abs. 45269): Geological Society of America, Abstracts with Programs, v. 16, no. 5, p. 336.

The Northern Miner, 1984, Valdez Creek partners plan mining by May: v. 69 , no. 46 , p. A1.

The Northern Miner, 1984, Alaska silver-zine bet for 3 Canadian firms: v. 69 , no. 52 , p. A-19. [Darby Mts.]

The Northern Miner, 1984, Queenstake Resources is bullish on its Alaskan gold property: v. 70, no. 12 , p. 1, 2. [Chichagof gold]

The Northern Miner, 1984, Geddes seeks funds for Windy-Craggy: v. 70 , no. 16, p. 12 .

The Northern Miner, 1984, Regional Resources now into major ore deposit: v. 70 , no. 16, p. 1 [Ag$\mathrm{Pb}-\mathrm{Zn}$ deposit, Bristish Columbia/Yukon border ]

Todd, J. C., 1984, Forest Service approves plan for Quartz Hill mine but timing of moly development is still unknown: Engineering and Mining Journal, v. 185 , no. 10 , p. 15.

Todd, J. C., 1984, Initial contracts awarded by Cominco for development of Ret Dog deposit: Engineering and Mining Journal, v. 185, no. 10, p. 17.

Western Miner, 1984, Queenstake Resources active on many fronts: v. 57 , no. 6, p. 7-10. [Chichagof]

Western Miner, 1984, Cominco on the hunt with Red Dog and Buckhorn: v. 57, no 4., p. 21-22. See also articles on Greens Crєek, p. 37, and Nyac dredging, p. 35.

Notes: (1) Howell, D. G., Jones. D. L., Cox, Allan, and Nur, Amos, eds., 1984, Procesdings of the Circum-Pacific Terrane Conference, v. XVIII of Stanford University Publications in the Geological Sciences contains many articles relevant to Alaskan geology.

(2) Alaska Construction and Cil has sections titled "Drill report" and "Petrobriefs" in many issues.

(3) As part of a "Northern Alaska Geochemical Study", rock sample analyses for 26 wildcat wells, as well as shale bulk density analyses for nine wildcat wells between Mikkelsen Bay and the Canning River (with emphasis on Exxon Alaska State A-1) are available from Petroleum Information (attn. Susan Just), 3380 C Str set, Suite 103, Anchorage, AK 99501. Some of this information is available for inspection only. See also the journal World Oil. 